\title{
minuicR
}

DOE/OR/11232-1

(DE82014250)

\section{Value of the Energy Data Base}

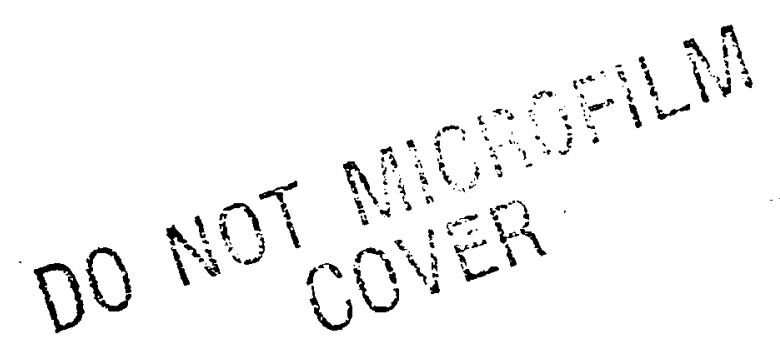

March 31, 1982

King Research, Inc.

6000 Executive Boulevard

Rockville, Maryland 20852 


\title{
DISCLAIMER
}

\begin{abstract}
"This book was prepared as an account of work sponsored by an agency of the United States Government. Neither the United States Government nor any agency thereof, nor any of their employees, makes any warranty, express or implied, or assumes any legal liability or responsibility for the accuracy, completeness, or usefulness of any information, apparatus, product, or process disclosed, or represents that its use would not infringe privately owned rights. Reference herein to any specific commercial product, process, or service by trade name, trademark, manufacturer, or otherwise, does not necessarily constitute or imply its endorsement, recommendation, or favoring by the United States Government or any agency thereof. The views and opinions of authors expressed herein do not necessarily state or reflect those of the United States Government or any agency thereof."
\end{abstract}

This report has been reproduced directly from the best available copy.

Available from the National Technical Information Service, U.S. Department of Commerce, Springfield, Virginia 22161.

Price: Printed Copy A05

Microfiche A01

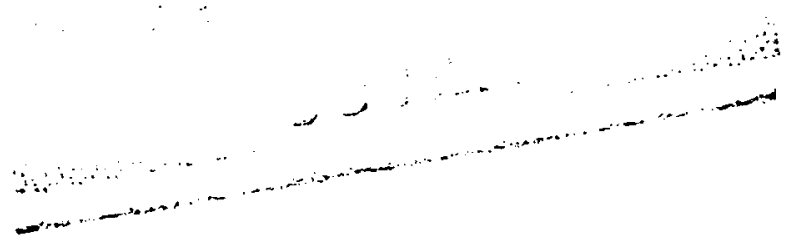




\section{DISCLAIMER}

This report was prepared as an account of work sponsored by an agency of the United States Government. Neither the United States Government nor any agency Thereof, nor any of their employees, makes any warranty, express or implied, or assumes any legal liability or responsibility for the accuracy, completeness, or usefulness of any information, apparatus, product, or process disclosed, or represents that its use would not infringe privately owned rights. Reference herein to any specific commercial product, process, or service by trade name, trademark, manufacturer, or otherwise does not necessarily constitute or imply its endorsement, recommendation, or favoring by the United States Government or any agency thereof. The views and opinions of authors expressed herein do not necessarily state or reflect those of the United States Government or any agency thereof. 


\section{DISCLAIMER}

Portions of this document may be illegible in electronic image products. Images are produced from the best available original document. 
$\mathrm{DOE} / \mathrm{OR} / 11232--1$

DE82 014250

\title{
VALUE OF THE ENERGY DATA BASE
}

\author{
Submitted by \\ Donald W. King \\ José-Marie Griffiths \\ Nancy K. Roderer \\ Robert R. V. Wiederkehr
}

Work Performed Under Contract No. AlO5-800R11232

King Research, Inc.

6000 Executive Boulevard

Rockville, Maryland 20852

\section{March 31, 1982}

\section{DISCLAIMER}

\begin{abstract}
This report was prepared as an account of work sponsored by an agency of the United States Government. Neither the United States Government nor any agency thereof, nor any of their employees, makes any warranty, express or implied, or assumes any legal liability or responsibility for the accuracy, completeness, or usefulness of any information, apparatus, product, or process disclosed, or represents that its use would not infringe privately owned rights. Reference herein to any specific commercial product, process, or service by trade name, trademark, manufacturer, or otherwise does not necessarily constitute or imply its endorsement, recommendation, or favoring by the United States Government or any agency thereof. The views and opinions of authors expressed herein do not necessarily state or reflect those of the United States Government or any agency thereof.
\end{abstract}

\section{Submitted to}

Technical Information Center

United States Department of Energy

Oak Ridge, Tennessee 37830 


\section{FOREWORD}

This report documents an assessment of the Energy Data Base (EDB) of the Department of Energy's Technical Information Center (TIC). As the major resource containing access information to the world's energy literature, EDB products and services are used extensively by energy researchers to identify journal articles, technical reports and other items of potential utility in their work.

The question of value of information products and services has been addressed in a number of studies over the years and is particularly relevant in the Federal information community today. In funding this study, the Technical Information Center supported the first full-scale test of the methodologies for assessing value which King Research has developed. Study results not only reflect the value of energy information but suggest broader assertions to be tested about the impact on value of information products and services.

The approach taken to assessing value here begins with the measurement of extent of use of the EDB and other identification methods and the resultant readings. Apparent value is measured in terms of willingness to pay, both for the searches performed and for the articles and reports read. Consequential value is measured in terms of effect-for searching, the cost of reading which results; and for reading, the savings which result from the application of the information obtained in reading. Resulting estimates of value reflect value to the searchers, the reader, and the reader's organization or funding source.

This report contains an executive summary and technical documentation of the project. The application of the methodology for assessing value developed during this study will be applied to specific issues where concepts of value can play a critical role. The first application will be documented in a separate report on Federal and Non-Federal Relationships in Providing Energy Information. This and other reports will be available from the Technical Information Center.

The conduct of this study required extensive collection and analysis of data on the services provided by TIC and on the uses of information by energy researchers. The entire staff of TIC, coordinated by our Project Officer, Bonnie Carroll, was unfailingly responsive with both data and explanations. The study methodology and results have also benefited from our reviews and discussions with TIC staff, particularly Ms. Carroll and William Vaden. Elizabeth Buffum, TIC Liaison, also provided support throughout the project. The KRI project staff included Dr. José-Marie Griffiths, Nancy K. Roderer, Dr. Robert R. V. Wiederkehr, and a team of interviewers and analysts ably coordinated by Sandra E. Brouard. The original draft was reviewed by Dr. Ernst R. Berndt of MIT, who provided very useful suggestions that were incorporated into the final draft.

The study was performed as a subcontract to Maxima Corporation.

Donald W. King

King Research, Incorporated 


\section{TABLE OF CONTENTS}

\begin{tabular}{|c|c|c|}
\hline Chapter & Title & Page \\
\hline 1 & EXECUTIVE SUMMARY & 1 \\
\hline 2 & BACKGROUND & 5 \\
\hline 2.1 & Description of the Energy Information System & 5 \\
\hline 2.2 & $\begin{array}{l}\text { Review of Literature on Value Assessments of } \\
\text { Information Products and Services }\end{array}$ & 7 \\
\hline 2.3 & $\begin{array}{l}\text { General Approach to Measuring the Value of Information } \\
\text { Products and Services }\end{array}$ & 13 \\
\hline 3 & ESTIMATING VALUE & 19 \\
\hline 3.1 & $\begin{array}{l}\text { Amount of Searching and Reading by Energy } \\
\text { Scientists }\end{array}$ & 19 \\
\hline 3.2 & $\begin{array}{l}\text { Effective Price of Searching and of Reading } \\
\text { Articles and Reports }\end{array}$ & 24 \\
\hline 3.3 & Calculation of Substitutes & 28 \\
\hline 3.4 & Value of the EDB & 29 \\
\hline 3.5 & Application of the Value Concept & 31 \\
\hline APPENDIX A & DATA COLLECTION METHODS & 33 \\
\hline APPENDIX B & PROGRAM AREA RESULTS & 55 \\
\hline APPENDIX C & SEARCHING COST MODELS & 63 \\
\hline \multirow[t]{3}{*}{ APPENDIX D } & $\begin{array}{l}\text { SAVINGS FROM REPORT READINGS (INDIVIDUAL } \\
\text { RESPONSES) }\end{array}$ & 71 \\
\hline & REFERENCES & 77 \\
\hline & BIBLIOGRAPHY & 79 \\
\hline
\end{tabular}




\section{CHAPTER 1}

\section{EXECUTIVE SUMMARY}

The U. S. Department of Energy currently expends about $\$ 5.8$ billion annually on research and development in the program areas of defense, nuclear science, basic research, and others. The return on this investment to the nation is basically achieved through the accomplishment of the specific goals and objectives of the R\&D and through use of the knowledge gained from the $R \& D$. There is abundant evidence that energy information plays an important role in current research and development activities. A survey of the 60,000 scientists and engineers funded by the Department of Energy shows that annually they read* about 7.1 million journal articles and 6.6 million technical reports. The total of 13.7 million readings includes 2.5 million by researchers in the defense program area, 2.2 million in the nuclear area, 3.0 million in basic research program areas, and 6.0 million in other program areas.

The energy information found in readings of articles and technical reports is used for many purposes, including application to research, management, and education of self and others. It is emphasized that the information acquired through reading helps teachers convey more extensive knowledge, scientists and engineers perform better research, and management make better decisions. Clearly, use of existing information saves researchers considerable time and effort. In a survey of DOE-funded scientists and engineers, many indicated that a recent reading of a technical report or article led to a savings of time and/or equipment. For example, a nuclear scientist reported savings of about $\$ 1,000$ from reading a report on steam electric plant construction costs and production expenses and thus not having to repeat the report's calculations. A wide range of savings values were reported for one-fourth of all article readings and three-fourths of all report readings. Over all readings of articles, there was an average savings of $\$ 590$ per reading; over all readings of

* Reading means examining an article or technical report beyond its title. technical reports, there was an average savings of $\$ 1,280$.

The total annual savings attributable to reading by DOE-funded scientists and engineers is estimated to be about $\$ 13$ billion. This is one estimate of the consequential value of primary energy information found in articles and technical reports. An estimate of the apparent value, or the cost of the 13.7 million readings, is $\$ 500$ million. One could look at the consequential value from the standpoint of a return on investment. The Department of Energy annually expends about $\$ 5.8$ billion on research and development. Of that amount, about $\$ 500$ million is expended in information processing and use, and the remaining $\$ 5.3$ billion is spent on other research-related activities which generate information. Thus,

$$
\begin{aligned}
& \text { Generation Information Future } \\
& \begin{array}{c}
\text { of } \\
\text { Information }
\end{array}+\begin{array}{c}
\text { Processing } \\
\text { and Use }
\end{array} \rightarrow \begin{array}{c}
\text { Saving to DOE } \\
\text { Scientists of }
\end{array} \\
& \$ 5.3 \text { billion }+\$ 500 \text { million } \rightarrow \$ 13 \text { billion }
\end{aligned}
$$

This suggests that an investment of $\$ 5.3$ billion in the generation of information and about $\$ 500$ million in processing and using information yields a partial return of about $\$ 13$ billion in terms of savings to scientists and engineers in their time and in equipment. Overall, this partial return on investment is about 2.2 to 1 . One way of expressing this relationship is that the DOE paid $\$ 5.8$ billion for the research, information processing, and use which in turn has been found to be worth at least $\$ 13$ billion.

It is clear that information products and services can substantially help achieve such return on $R \& D$ investment through providing better information and increasing use of information. Factors related to increased value of information are depicted in Figure 1.1. As shown, better information can be achieved through such processes as refereeing and 


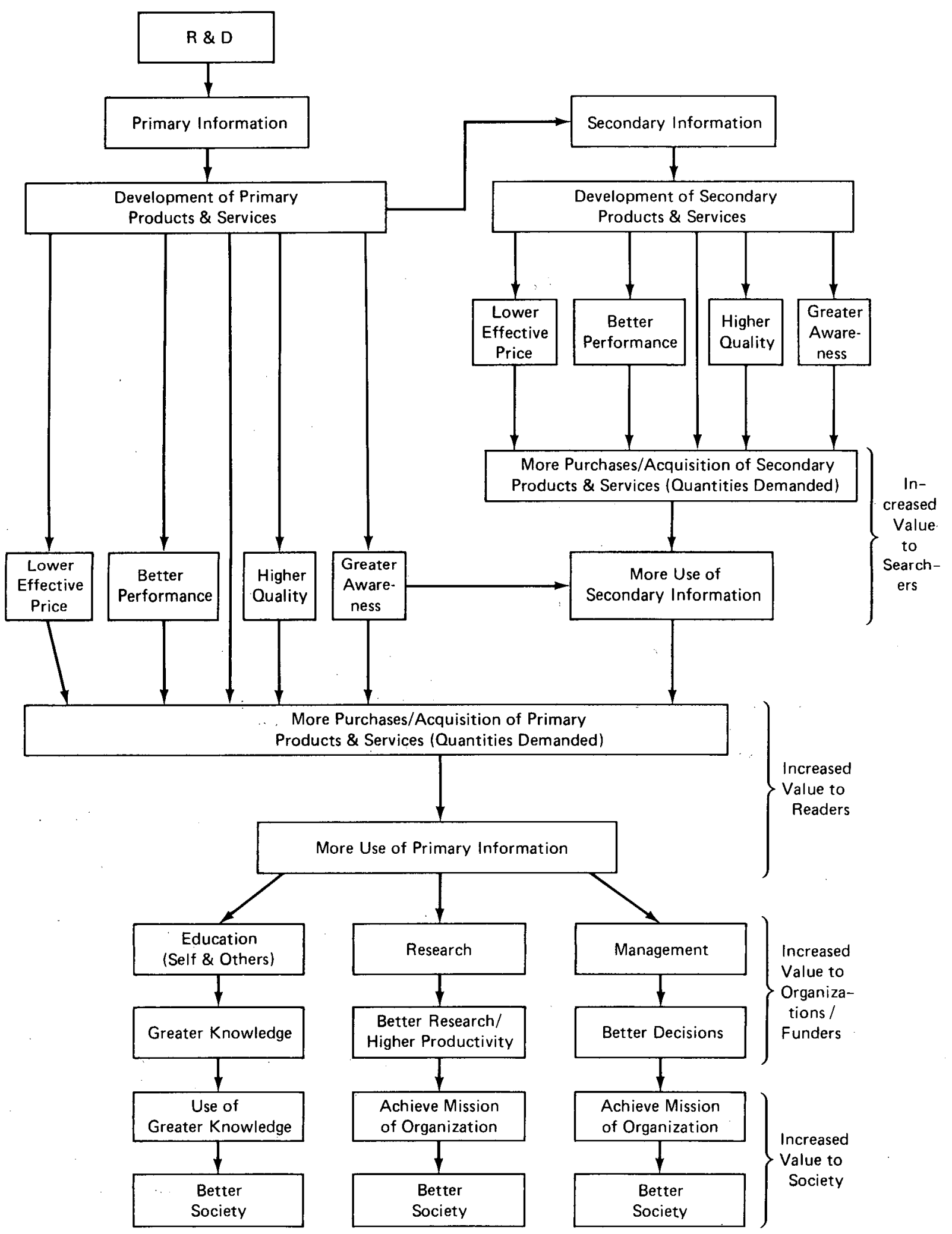

Figure 1.1 Factors related to increasing value of information.

editing materials, supporting compilations and analyses of information, and so on. Use of information can be increased through higher quality of information, better performance (e.g., rapid response to requests for copies of technical reports), lower prices (which increase purchases or acquisition), and increased awareness of technical reports and journal articles through use of secondary products and ser- 
vices such as printed bibliographies and on-line bibliographic services. These improvements in turn lead to increased value to readers, their organizations and funders, and ultimately to society.

The DOE Technical Information Services program managed by the Technical Information Center (TIC) is an Energy Program which has the responsibility of managing the information products from the multibillion dollar R\&D program and maximizing their use by Department staff and contractors. For example, TIC helps increase use of technical reports by making copies available in paper copy and in microform. It is estimated that reports distributed by TIC are read 6.8 million times by DOE and non-DOE researchers. If $\$ 1,280$ is the average savings value derived from each reading, then this service has a potential of yielding savings of over $\$ 8$ billion to the overall energy community. TIC also enhances the use of information through systems which provide effective access to energy-related technical reports, journal articles, and other materials produced worldwide. The major resource containing access information to these materials is the Energy Data Base (EDB). In 1981 it was estimated that the cumulative amount of the international $R \& D$ investment represented in the EDB was over $\$ 139$ billion. The savings value derived by DOE researchers is enhanced by the ability to carefully select relevant items for reading from this data base resource. A number of TIC products and services are related to the EDB and aid this selection process. These include the published index, Energy Research Abstracts (ERA), and the on-line bibliographic retrieval system, RECON. In fact, it was found for DOE researchers, there are about 70,000 searches performed annually using RECON and an estimated 244,000 searches performed annually using ERA and other TIC-produced indexes. About 2.6 million of the total 13.7 million readings of energy articles and technical reports are directly attributable to use of EDB secondary information in some form. DOE scientists and engineers also conduct searches using other on-line systems and printed indexes making a total of 4.6 million readings derived from bibliographic searches.

Searchers must constantly make judgments concerning whether and how to expend money, labor, materials, and equipment on searches. Decisions are usually made in light of tight budgets so that resources are not expended casually. DOE-funded searchers annually expend about $\$ 47$ million on all secondary energy information. The consequential value of the secondary energy information can be measured by the apparent value of reading articles and technical reports identified through the secondary energy information and by the further consequential value of reading these materials. The apparent value of the items read as a consequence of using the secondary energy information is $\$ 164$ million, and the further consequential value in terms of time and equipment savings is $\$ 4.4$ billion. Similar results are derived for TIC secondary information products and services resulting from the Energy Data Base.

In determining the value of the Energy Data Base, only those searches and those readings that are directly attributable to the EDB are included in the analysis. There are a total of 1.0 million readings from 70,000 RECON on-line searches, 600,000 readings from 40,000 on-line searches of the NTIS data base, and 1.6 million readings from 244,000 searches of ERA and other TIC indexes. The values directly attributable to the EDB are given in Table 1.1 The numbers given do not include the value associated with reading of technical reports received on standard distribution from TIC. These 3.3 million readings are associated with an additional $\$ 122$ million in reading value, for a total of $\$ 239$ million, and

Table 1.1 VALUE OF INFORMATION TO SEARCHERS, READERS, AND ORGANIZATIONS/FUNDERS WHICH IS DIRECTLY ATTRIBUTABLE TO THE ENERGY DATA BASE: DOE-FUNDED SCIENTISTS AND ENGINEERS, 1981*

\begin{tabular}{|c|c|}
\hline - & $\begin{array}{l}\text { Value directly attributable to } \\
\text { the Energy Data Base }\end{array}$ \\
\hline Searchers & $\$ 20$ million \\
\hline Readers & $\$ 117$ million \\
\hline $\begin{array}{l}\text { Organizations/Funders } \\
\text { (DOE) }\end{array}$ & $\$ 3.6$ billion \\
\hline
\end{tabular}

*Source: King Research, Inc. 
$\$ 4.2$ billion in value to DOE, for a total of $\$ 7.8$ billion. Of the total funds expended for energy information, the values directly attributable to TIC products and services are 43 percent of the total for searchers, 48 percent for readers, and 60 percent for the funding organization (DOE).

For those funding EDB searchers, one could evaluate searching by treating the $\$ 20$ million amount paid by searchers as cost and the consequence in readings as benefits. Apparent value of the reading directly attributable to EDB searching is $\$ 117$ million. The benefit-to-cost ratio of EDB searching is thus 5.9 to 1 , and the net value is $\$ 97$ million. Similarly, evaluation of reading would compare the EDB reading costs of $\$ 117$ million against the $\$ 3.6$ billion savings which results in a benefit-tocost ratio of about 31 to 1 or a net value of $\$ 3.5$ billion. For all reading of energy materials, total costs of $\$ 500$ million can be compared against the $\$ 13$ billion savings which results in a benefit-to-cost ratio of 26 to 1 and a net value of $\$ 12.5$ billion.

Another approach to assessing the value of the Energy Data Base is to consider what would occur in its absence. Energy scientists and engineers can search or identify energy information by means other than the EDB products and services. For example, some of the chemically related journal articles can be found in the Chemical Abstracts Services' products; nuclear secondary information can be found in INSPEC products, etc. It generally costs more to do so, and searching of several data bases may be required to achieve comparable results. In addition, some items are covered only in the EDB. If the EDB (or specific EDB products or services) were dropped, some substitute means of searching would be adopted. This means that either costs to the searchers would be higher or, under fixed budgets, there would be fewer searches with consequences of correspondingly fewer readings and less savings from the readings:

The way in which we calculate the apparent and consequential values of EDB products and services is to determine the direct effects of the searches that would be lost by substituting other products and services and assuming a fixed total budget. There are three types of secondary products and services that use the EDB information: RECON, ERA, and other printed indexes; other on-line services such as Lockheed Dialog and others that have the NTIS data base (which includes many EDB items); and BRS which provides access to the EDB. By dropping all these products and services and substituting others, there would be 354,000 fewer searches and therefore 2.5 million fewer readings. This results in the reduction of searcher apparent value by $\$ 15$ mil- lion, consequential value to readers by $\$ 90$ million, and the value of savings in time and equipment by $\$ 3$ billion.

The latter figure, $\$ 3$ billion savings in labor and equipment from the EDB products and services, can be roughly translated into productivity. If it is assumed that, with the EDB, research and development costs $\$ 5.8$ billion for a given level of output, without the EDB the same output would require an investment of $\$ 8.8$ billion. This is an increase in productivity of about 52 percent. This says that to accomplish the same R\&D output without TIC information services, the R\&D budget would have had to have been $\$ 3$ billion higher.

A similar analysis can be carried out to consider the value of RECON only. For the 70,000 RECON searches conducted, value to searchers is $\$ 7.3 \mathrm{mil}$ lion, value to readers is $\$ 36$ million, and value to DOE is $\$ 900$ million. In evaluating searching, we find a benefit-to-cost ratio of 5.1 to 1 and a net value of $\$ 28.7$ million. In evaluating reading, the benefit-to-cost ratio is 25 to 1 , and the net value is $\$ 864$ million. If RECON search services were not provided and available substitutes were used, the difference in consequential value would be $\$ 700 \mathrm{mil}$ lion. This savings in labor and equipment from RECON represents roughly a 14 percent increase in overall research productivity.

Value assessments were also conducted separately for five major research areas funded by DOE: defense; nuclear science; and basic energy science, fusion, and health and environmental research, components of the basic research program. Separate reports are provided elsewhere for each of these areas with summary results given in this report. Differences were found in the level of reading by researchers in the different program areas, in the methods used to identify materials, and in the value associated with reading. Average annual researcher's readings of technical reports and articles ranged from 203 in the defense area to 276 in the fusion area. Printed index searching was used most heavily in the areas of nuclear, health and environmental research, and on-line searching in the basic energy sciences. Fusion researchers made greater use of standard distribution copies of reports from TIC. Value associated with report reading was estimated to range from $\$ 930$ in the health and environmental research area to $\$ 1,840$ in the fusion area. Looking at individual research budgets within the program area, we see that increases in productivity as a result of EDB products and services were calculated as ranging from 24 percent for health and environmental research to 94 percent for nuclear research programs. 


\section{CHAPTER 2}

\section{BACKGROUND}

The objective of this project performed for the Technical Information Center was the assessment of the value of the Energy Data Base (EDB). Building on previous work in the area, we identified levels of benefit or value and developed a methodology for assessing value. The methodology was then applied to the Energy Data Base to determine the net benefit derived from the provision of EDB products and services. Value was estimated for five program areas within DOE as well as for the overall information activities. Also considered were the effects on EDB value of various public and private sector arrangements, possible pricing alternatives, and constraints on information flow.

Considering the value of the Energy Data Base begins with an understanding of the information products and services provided from it and the role that these products and services play in the overall energy communication cycle. Energy information is generated, reproduced, disseminated, and used; the EDB serves primarily to facilitate use by providing a means of identifying primary information sources. It is this function of the EDB that we have concentrated on in looking at value.

All levels of value addressed reflect the contribution of the EDB to the use of the primary literature. First, the volume of energy information distributed to and used by the DOE-funded research community is identified. Value is then considered in terms of user willingness to pay for the information, the effect of information obtained on work, and the effect of the work performed on the organization and society. We consider the amount paid for information, including time spent as well as monetary expenditures, to be a measure of apparent value. This is distinguished from consequential value, which reflects savings achieved by application of information.

The following sections address the background for this study, including a description of the energy information system, a discussion of the relevant literature on the value of information, and an over- view of the approach and methods used by King Research. Chapter 3 covers the actual calculation of study results.

\subsection{DESCRIPTION OF THE ENERGY INFORMATION SYSTEM}

Figure 2.1 describes the components of the generalized energy information system as they relate to the EDB. At the left and top of the figure are various forms of primary information, including journal articles, DOE reports, non-DOE reports, and other materials. Each has a variety of channels of distribution, such as reprint/preprint copies, individual subscriptions, and institutional subscriptions for journal articles. DOE reports are distributed by TIC, in paper and microfiche form on standard distribution and to the National Technical Information Service (NTIS) and the Government Printing Office (GPO) for further distribution. The different forms of energy information are described by the Energy Data Base, from which general printed indexes are generated and which is also used as the basis for on-line searching through RECON and other systems. Users of this array of primary and secondary products and services include both organizations, primarily libraries, acting on behalf of groups of researchers and individual researchers themselves.

The primary materials described in the EDB include energy reports, journal articles, and other materials. The number of items added to the EDB in 1981 was about 150,000 , reflecting the volume of relevant literature published. This includes about 24,000 DOE reports distributed by TIC.

The volume of DOE reports distributed from TIC is reflected in Table 2.1. About 8,300 titles are distributed automatically from TIC to a categorized standard distribution list; on the average, about 250 copies of each report are sent out. In total there are over 4,000 addresses at approximately 2,000 institu- 


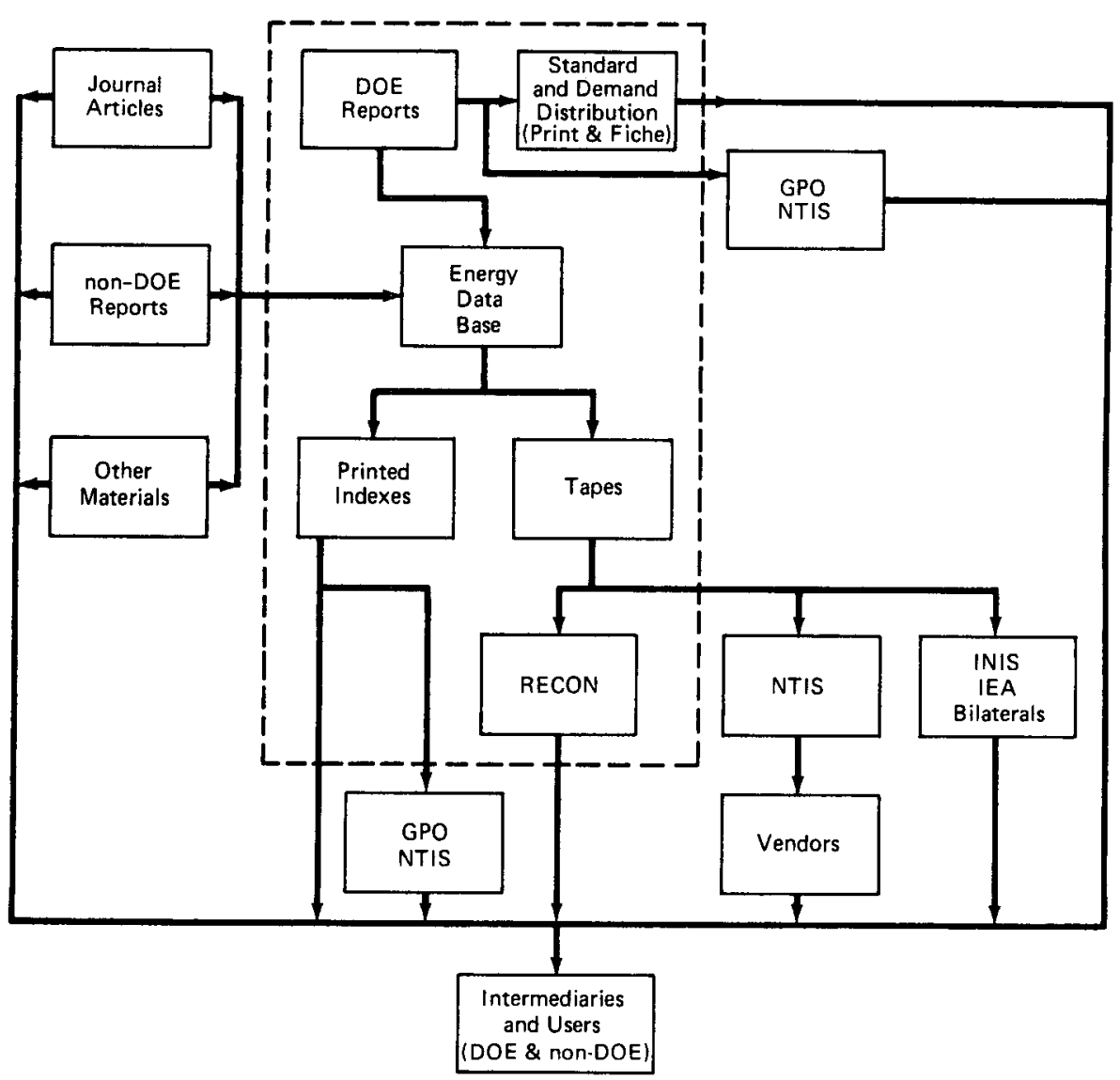

Figure 2.1 The energy information system and the EDB. Dotted line indicates TIC activity.

Table 2.1 DOE REPORT DISTRIBUTION*

\begin{tabular}{lrc}
\hline \multicolumn{1}{c}{ Channel } & $\begin{array}{c}\text { No. of } \\
\text { titles }\end{array}$ & $\begin{array}{c}\text { Copies distributed, } \\
\text { in millions }\end{array}$ \\
\hline TIC & & \\
Standard distribution (paper) & 8,300 & 2.1 \\
$\begin{array}{l}\text { Standard distribution (fiche) } \\
\text { On-demand distribution }\end{array}$ & 25,300 & 2.8 \\
$\quad 25,300$ & 0.7 \\
$\quad$ Total TIC distribution & & 5.6 \\
NTIS & & \\
Standard distribution (fiche) & 15,000 & 0.4 \\
On-demand distribution & 15,000 & 0.2 \\
$\quad$ Total NTIS distribution & & 0.6 \\
Total distribution & & 6.2 \\
\hline
\end{tabular}

*Source: King Research, Inc. 
tions on the standard distribution list. A fiche standard distribution, again by category, is also made; here 100 copies on the average are distributed. About 15,000 titles also go on to NTIS for further distribution and are sent out by them under their automatic microfiche distribution service, SRIM. About 40 fiche copies per title are sent out via SRIM. In addition to the various forms of automatic distribution, both TIC and NTIS provide on-demand copies of reports to their respective user audiences. Collectively through these major channels some 6.2 million report copies are distributed; other channels such as author distribution and the Government Printing Office also do some distribution of reports.

Journal articles covered by the EDB come from a wide range of scientific and technical journals published by societies, commercial publishers, and others. In 1981, there were nearly 10,000 scientific and technical periodicals published in the U. S., with several hundred directly in the energy area and others containing relevant articles. About half of the items covered by the EDB are journal articles.

From the EDB, ten printed indexes were generated in 1981: Energy Research Abstracts and Energy Abstracts for Policy Analysis, distributed by the TIC and GPO, and Current Energy Patents, Energy Conservation Update, Energy and the Environment, Fossil Energy Update, Fusion Energy Update, Geothermal Energy Update, Solar Energy Update, and Synthetic Fuels Update, distributed by the TIC and NTIS. Energy Research Abstracts $(E R A)$ is a comprehensive semimonthly publication going to approximately $800 \mathrm{DOE}$ program addresses from TIC and approximately 330 paid subscribers from GPO. The other nine indexes, all monthly, are distributed to an average of about 230 DOE program addresses and 170 paid subscribers.

The EDB is also searched on-line through RECON and beginning in 1981 through commercial search services. Approximately 70,000 RECON searches are performed annually by users in 417 DOE-funded institutions (with about 650 passwords). Items available through NTIS may also be identified through NTIS's on-line files, which cover EDB materials. A number of other cooperative arrangements are in effect which result in portions of the EDB being available in other on-line files.

Use of the EDB products and services and energy materials include both libraries and individuals. For this study, estimates of both the number of organizations and the number of researchers were developed. The 417 RECON sites are identified as a core group of organizations, with a larger organizational user community defined as the approximately 2,000 organizations on the TIC standard distribution list. The RECON sites are included in the total figure.

The number of energy researchers funded by the Department of Energy is estimated at 60,000 (see Section 3.1). These estimates are based on funding levels and average $R \& D$ expenditures per scientist and include scientists and engineers working on energy research and development. This can be viewed as the primary user community; there are clearly other user groups including industrial researchers and the educational community.

The basis of the estimates of value of the EDB developed in this report is the level of use of energy information products and services by this primary user community. Estimates of use are described in detail in Section 3.1, but can be summarized in an analysis of the activities of an "average" energy researcher. On the average, an energy researcher conducts or has conducted about 5.4 manual index searches and 2.9 on-line searches per year. Through these searches, some 41 reports and 37 articles are identified and ultimately read. Total reading by the energy researcher is 110 reports and 118 articles, consuming an estimated 165 and 118 hours of time spent reading. Total average reading time is thus about 280 hours per year per energy scientist or engineer. Over all energy researchers, about 17 million hours are spent reading approximately $6.6 \mathrm{mil}-$ lion reports and 7.1 million journal articles.

\subsection{REVIEW OF LITERATURE ON VALUE ASSESSMENTS OF INFORMATION PRODUCTS AND SERVICES}

The published literature addressing the value of information, information systems, information products, and information services falls into two categories:

1. That which describes the concept of value and approaches to measuring value

2. That which describes the actual application of the measures to information products and services

The literature falling into each of these two categories is presented in the two following subsections. The final part of this section is a discussion of the reported problems encountered in attempting to assess value.

\subsubsection{CONCEPTS OF VALUE AND APPROACHES TO VALUE ASSESSMENT}

The literature falling into this category is considerably more voluminous than that reporting actual 
applications of value assessments. The reason for this lies in the lack of consensus concerning the notion of value itself. Value is an attribute (it does not exist on its own) which can be applied to almost any entity. The act of attributing a value to something is, in effect, the establishment of an equivalence relationship (or set of such relationships). We can express this by the equation:

$$
\mathrm{V}_{\mathrm{A}} \equiv \mathrm{V}_{\mathrm{B}}
$$

where the value of $\mathrm{A}$ is equivalent to the value of $\mathrm{B}$ and $A \neq B$. $A$ and $B$ may be the same type of entity but the relationship conveys no information if $A$ and $B$ are identical. Usually $A$ and $B$ are very different. Consider, for example, the following statements of value:

1. The value of my house is $\$ 100,000$.

2. $\$ 10$ is equivalent to $£ 5$.

3. A reliable car is worth its weight in gold.

4. My catapult is worth 5 of your marbles.

Equivalence statements of this type define what one would be prepared to exchange for the entity being valued (if circumstances were such that the exchange was desirable or necessary), in other words, the exchange value. Most frequently, one side of the relationship is expressed in monetary terms, as in Example 1 above. The problems associated with determining the numeric dollar value of an entity are discussed in Section 2.3. However, this common coupling of dollar amounts with values leads to some confusion between value and price and between value and cost. Price is the dollar amount that has been determined for an item or product by the owner of that item or product. To a certain extent one might consider this the dollar value attributed to that item or product by its owner as it is the dollar amount he/she would be prepared to accept in exchange for the item or product. However, a market economy does not behave in such an ideal way, and the concepts of demand, availability, and utility confound the determination of price. Price is therefore the dollar amount exchangeable for an item or product. Cost, on the other hand, is the total dollar amount required to produce the item or product.

Value has three further characteristics. First, value is subjective. Value assessments can be made by individuals, groups, organizations, or society as a whole. Assessments are situation dependent and, consequently, variable over time. Finally, value can be either positive or negative. Manifestations of positive value are benefits, and of negative value, detriments. The characteristics of value can be summarized as follows:
$\mathrm{V}_{\mathrm{A}} \equiv \mathrm{V}_{\mathrm{B}}$

$A \neq B$

A \& B can belong to the same set

$\mathrm{V}_{\mathrm{A}}, \mathrm{V}_{\mathrm{B}}$ can be positive or negative

$V_{A}, V_{B}$ can vary with time

Fritz Machlup ${ }^{1}$ distinguishes between exchange value and use value which are often used in economics to solve the "paradox of value." This paradox refers to the low or zero price of extremely useful things, such as air and water, versus the high price demanded for relatively useless things, such as gems. The solution of the paradox lies in the availability of the various items. Relative scarcity and marginal utility are the concepts used to explain the value of small amounts of the item regardless of the value of the total amount available.

Rather than consider cost or price as measures of value, the most prominent approach to value measurement is based on the willingness-to-pay concept. This is an extension of the value-price relationship. The main drawback of a straightforward willingness-to-pay measure is that it considers only that portion of value attributable to the acquisition of an item.

Consequently, a second approach to measuring value has evolved which considers the use of an item or product. Taylor ${ }^{2}$ writes:

The value of information has meaning only in the context of its usefulness to users. There is no way of analyzing value of information except by reference to the environment of those who are its intended clientele.

$\mathrm{Rich}^{3}$ states that use is only a preliminary or rough indicator of value when goals are clearly defined and the information being used is directly related to those goals. He continues by identifying several categories of use which, when combined, give a first cut at assessing value. The first two categories of use are intended use and actual use. The other uses identified are instrumental use and conceptual use. Instrumental use refers to situations in which the specific way information is used can be documented. Conceptual use refers to influencing a person's thinking without application to any specific documentable use.

So far, we have introduced two approaches to value assessment - willingness to pay and use. Yet another approach is the analysis of impacts. Impact measures aim to describe not only the types of information that are used, but also how they are used. Some measures of impact try to relate the use of information with the stage in policy formulation or decision making in which it is used. Other empirical measures of impact include extensive citation analyses, number of different uses made of sample 
studies, and budgetary R\&D expenditures by agencies over time. Each of these approaches to measurement of impacts focuses on the relationship between information generators (researchers) and users, or on decision making and use.

Finally, there are a number of additional approaches to measuring value which relate, at least in part, to one or other of the three key approaches outlined above. Related to the willingness-to-pay approach is one that considers the price-demand relationship. ${ }^{4}$ The demand curve of economic theory is the curve showing the number of people willing to pay more than any given price. The sum of the values received by all buyers who purchase a product or service, not available elsewhere, and offered at price $P$, is the area lying under the demand curve as indicated in Figure 2.2.

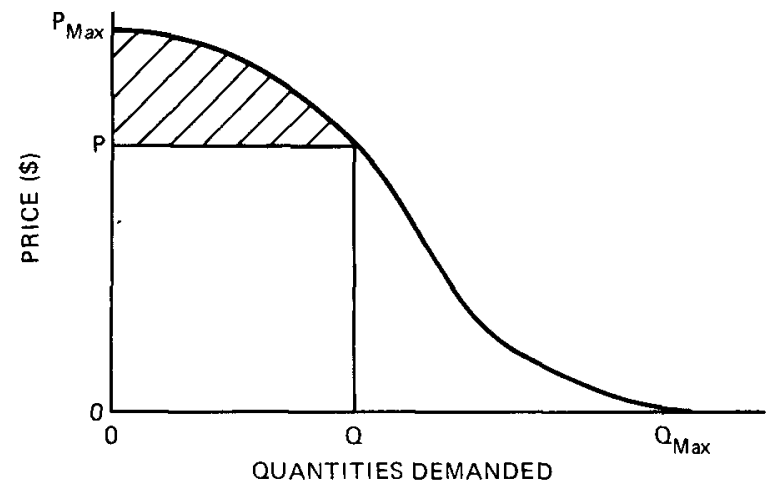

Figure 2.2 Price-and-quantities-demanded relationship.

However, Machlup ${ }^{1}$ disagrees with this measure:

This method has been accepted by some economists for small changes in prices charged or quantities taken, but has been roundly rejected for determining total values obtained by buyers or takers of any goods or services.

He rejects, in particular, the inclusion or integrability of unpaid utility or consumer surplus (i.e., the area above the actual price paid).

An extension to this approach has been presented by King et al. $^{5}$ They use the effective price in place of price and the observed demand in place of demand. The effective price is made up of the actual price of a product or service plus the costs incurred in identification, location, acquisition, use, and application. Demand is viewed as being a function of many attributes including distribution, presentation, and awareness.

Related to those approaches considering use of information or information products and services are measures of utility. Hirshleifer and Riley ${ }^{6}$ describe the application of utility theory to the underlying processes of decision making. They view the conflict between social goals of achieving efficient use of information once it has been produced and ideal motivation for the production of information as a significant problem to researchers.

Relating to utility and to impact analysis is the concept of productivity. Taylor ${ }^{7}$ discusses many problems associated with both the definition of productivity and its measurement. The usual definition of productivity is "output per man-hours worked." However, this is only a partial measure as it does not include investment in equipment, in system development, in increased know-how, and in a supporting communications network. Problems are associated with defining input (moving beyond a straightforward consideration of labor hours) and output (difficulty, error rate, and quality are hard to measure).

\subsubsection{APPLICATION OF MEASURES OF VALUE TO INFORMATION PRODUCTS AND SERVICES}

This section describes the application and use of some of the approaches to value assessment outlined in the previous section. Following the same framework the applications are organized, as much as possible, in accordance with their relation to the approaches:

- Willingness to pay

- Use

- Impact analyses

Mason and Sassone ${ }^{8}$ use an economic modelling approach to describe information service centers and the potential and actual users of such centers. The model relates economic costs to economic benefits. A distinction is made between private and social costs and benefits. Costs are measured by resource investment and benefits by the users' willingness to pay as described by a demand curve.

The total benefit derived from use of an information service center is represented graphically as the area beneath the demand curve (i.e., total willingness to pay) up to the maximum quantity of services purchased. The area beneath the supply curve represents total costs. The net benefit is then represented by the area beneath the demand curve less the area beneath the supply curve. The total net benefit is the difference between the net benefit without the center and the net benefit with the center. The quantitative measure of benefits used by the model is the time the user saves by using a particular information analysis center service rather than acquiring the same information by an alternative method. The model assumes that the potential user has access to several sources for obtaining information of equivalent quality and is motivated solely by economic efficiency. This approach essentially provides a "first cut" cost-benefit analysis. The reason for this is because the approach ignores 
the social benefits of acquiring the information and any benefits accruing to society that result from the private benefits. It also ignores some of the userincurred costs of ordering, acquiring, and using the information.

Another approach using the willingness-to-pay approach, combined with the time saved by researchers as a result of their use of information services, was used by Berg. ${ }^{9}$ He utilizes the following relationship for estimating the demand curve:

$$
\mathrm{Q}=\mathrm{f}(\mathrm{P}, \mathrm{X}, \mathrm{N}, \mathrm{J})
$$

where $Q=$ the circulation

$\mathrm{P}=$ the subscription price

$X=$ the number of pages

$\mathrm{N}=$ the number of researchers in the field

$\mathrm{J}=$ the number of journals in the field

Flowerdew and Whitehead ${ }^{10}$ discuss, in considerable detail, the application of cost-benefit analysis in information science and the problems encountered in measuring benefits. They concentrate on the willingness-to-pay approach, and in particular on the unavoidable question of whether to assess the willingness to pay from the viewpoint of the individual or the organization with which he/she is associated. Dammers ${ }^{11}$ asked users to rate SDI services according to their individual needs and finances and discovered that this resulted in a tendency to overvalue the services. Hawgood and Morley ${ }^{12}$ asked users of information services how much they would be willing to pay for the services and how much they felt their organization should be willing to pay in an attempt to compensate for overvaluation. Wolfe et al. ${ }^{13}$ also took into consideration the difficulty in distinguishing benefits to individuals and organizations. Research and development workers were asked to estimate:

1. Increase in salary required to compensate for loss of secondary information

2. Adjustment of hours devoted to R\&D and information gathering if secondary information is withdrawn

3. Readjustment of hours after loss of secondary information to achieve the same output

These estimates are very difficult to make, particularly in a general sense, but do suggest the useful concept of replacement.

Wills and Oldman ${ }^{14}$ analyzed the contribution that cost-benefit analyses have made, and could make, to the evaluation of libraries. The measures they used included:

- Individual's predisposition to use the library
- Their patterns of information acquisition from the library

- Their use of library products

- Effects on subsequent behavior

However, the measures were determined in a qualitative fashion. The investigators aimed at examining the "origins of library use and the effects of library use as a basis for determining library impacts," and consider such a qualitative approach as a precursor to more quantitative approaches.

A study to research the value and use of the New England Marine Resources Information Program was conducted by Della Bitta; Johnson, and Loudon. ${ }^{15}$ Their study aimed to provide information about the market of NEMRIP and to assess the value of its publications in meeting the educational needs of its readership. In particular they looked at:

1. Selected characteristics of NEMRIP's market

2. Requestors' readership patterns for 20 publications

3. Patterns of usage for information derived from the 20 publications

4. Requestors' evaluations of the usefulness of that information

5. "Pass-on" rates-the passing-on of publications to additional users was found to increase exposure to the information contained in the 20 publications by 74 percent

6. Extent of reading

7. Difficulty of reading

8. Familiarity with the information in the 20 publications

The study concluded that although the NEMRIP disseminates information that is useful and has a positive impact on users, several possible changes in publication policy would improve the value of the program to its users.

A study to assess the comparative use and value of INSPEC services was performed by Hall. ${ }^{16}$ The various services evaluated were individual profile SDI, standard profile SDI, current awareness publications, and abstract journals. Each of the four services was rated by users on a 100-point scale both with and without considerations of cost. In addition to the user assessment the study analyzed:

- Subscribers by type of organization

- Method of dissemination

- User needs

- Service characteristics

A cost-benefit study of the NASA Technology Utilization Program, conducted by the Denver 
Research Institute ${ }^{17}$ is discussed by Mogavero. ${ }^{18}$ The principal objective of the study was to quantitatively assess the effectiveness of each of the information product packages made available to industry through the Program's information transfer mechanisms. Such a quantitative analysis required consideration of:

- Cost to NASA of making information products and services available

- Cost to the user of making use of those information products and services

- Economic benefits realized, or expected, in new or improved products, processes, or services

The overall benefit-to-cost ratio was then calculated as

$$
\mathrm{R}=\frac{\mathrm{B}-\mathrm{Ca}}{\mathrm{Cn}}
$$

where $\mathrm{B}=$ gross user benefit

$\mathrm{Ca}=$ user cost

$\mathrm{Cn}=$ NASA production cost

In this formulation, user costs reduce the gross benefit. User costs associated with the user functions of identifying, acquiring, and reading information sources were not explicitly identified.

Benefit-to-cost ratios of up to $12: 1$ have been identified for specific scientific and technical information systems. ${ }^{17}$ Most of these systems were quite small (typically serving a few hundred people), and only benefits derived from cost savings in information dissemination were considered.

In another study of information analysis centers, Mason $^{19}$ measured user perceptions of the relative value of information service characteristics. The conclusions of the study were that the nine service characteristics investigated could be described in terms of just four independent dimensions:

- Data or information quality (precision, accuracy, and source credibility)

- Scope (recency and completeness)

- Hassle (time lag, ease of access, and ease of use)

- Cost

Hounsell ${ }^{20}$ reports on a small-scale study to make a preliminary assessment of the potential value of the ERIC data bases for educators in Britain. The determination of value was based on end-users' assessments of:

- Level of interest in the retrieved bibliographic citations

- Their novelty

- Relevance and value of the documents which were acquired as a result of searches on the ERIC data base

Value was not defined, but users were asked to assess the value of a document to them in their work according to a four-category breakdown.

Schwuchow ${ }^{21}$ performed a study to investigate the efficiency of information and documentation (I\&D) systems. The main objectives of the study were to:

- Develop and test standard systems and methods for cost accounting in I\&D systems

- Establish indices for costs of individual activities in I\&D systems (e.g., cost of acquisition, bibliographic description, textual analysis, keyboarding, storage, retrieval, etc.)

- Develop different practicable approaches to and methods of determining the level of performance, efficiency, and usefulness of I\&D systems

The benefits of I\&D services were measured by the degree to which they contribute to the attainment of specific goals (e.g., increase in revenue and profit, improvement of personal performance and productivity, reduction of time and money invested in the acquisition of information, cost reduction through avoidance of duplicate research) and the attainment of specific societal goals (e.g., increase in the general level of education, improvement of public access to information, and increase in capacity for research and development).

Several measures of individual benefit are defined as "relatively easy to measure." For example:

- Time and expense saved by the individual users or their institutions

- Increased revenues and profits in industrial enterprises

Any attempts to quantify social benefits are considered highly unreliable. The study concludes that any cost-benefit investigation in the I\&D area should "not be carried out with the objective of establishing what portion of public resources should be appropriated for this entire sector... Rather, such an investigation should proceed from a fixed public budget covering the whole I\&D area and restrict itself to determining how to distribute this budget most rationally...among the individual I\&D activities and systems."

Baumol and Ordover ${ }^{22}$ investigate the potential for private financing of information transfer by considering the example of library-owned scientific journals. While not addressing value directly, they do study the cost implications of small changes in jour- 
nal publication practices, for example, the marginal cost of:

- Providing a journal to an additional subscriber for 1 year $=\$ 5-\$ 35$

- Providing a single issue to an additional subscriber $=\$ 1-\$ 2$

- Providing a single page to an additional subscriber $=\$ 0.06-\$ 0.09$

- Adding 1 page to 1 issue of a journal = $\$ 63-\$ 71$

In addition, they discuss the cost of user time (resulting from the time and effort expended in getting to a library), the circulation costs (location, physical retrieval, checkout, checkin, reshelving), and the costs attributable to "congestion" (loss of time one user imposes on other library users).

A somewhat different approach to value assessment was taken by Hawgood and Morley ${ }^{23}$ in an attempt to infer the value placed on different aspects of library service by the library authority. The underlying model was based on the allocation of resources (such as staff time, book budget, space) to each service produced by the library. The study analyzed the resource allocation decisions of the library authority. The main drawback of the model, as reported, lies in its assumption that library service operations have been optimized by library staff.

So far, the discussions in this section of the report have identified a number of basic approaches to the concept of value and its measurement. Some of these approaches have been applied to studies of existing information products and services although most of these have considered only one aspect of value (for example, from a rational economic viewpoint or from a user's qualitative perceptions). One or two of the studies do combine two or three aspects, such as willingness to pay and time saved. These previous assessments of value of information products and services are, therefore, incomplete. In this study we attempt to combine several quantitative measures of value to reach a more realistic assessment of the value of TIC information products and services to the energy community. We have also looked more closely at the value relationships between secondary information services and primary information. The approach we use is described in detail in Section 2.3.

\subsubsection{PROBLEMS IN MEASURING THE VALUE OF INFORMATION PRODUCTS AND SERVICES}

One of the key reasons for the lack of quantitative value assessments of information products and services is the problem of measuring value which, as discussed previously, is a subjective or collective equivalence relationship. The problems encountered in attempting to achieve some degree of objective measurement are attributable to:

- Nature of information and derived products and services

- Integration relationship between information and knowledge

- Subjective characteristics of value

- Ambiguity of viewpoint from which to measure value

One major barrier to the collection of meaningful data concerning the benefits of information services is the conceptual difficulty of individuals in distinguishing between the value of the information and the value of the information product or service that provided the information. Mason ${ }^{19}$ expands:

\footnotetext{
The intrinsic value of the information may be a valid measure of the benefit of an information center service. However, this value is the value of the information service only if the information center is a monogamist and provides unquestioningly unique information.
}

Further problems relate to viewing information as a commodity. For example, Marschak ${ }^{24}$ comments on the lack of correlation between volume of information and its value.

Flowerdew and Whitehead ${ }^{10}$ list several noncommodity aspects of information:

- When obtaining information it cannot be assumed that the whole price is a measure of the value of that information to the purchaser

- There is no obvious measure of a unit of information

- Information is mainly an investment good although it has consumption aspects

- Incomplete a priori knowledge of the value of the information sought

- Incomplete a priori knowledge of the uses for the information

- Benefits and costs may not be fully obtained and borne by the consumer and producer

- The individual who decides whether or not to use an information service is not necessarily the main beneficiary from that decision

All of the above difficulties relate to the nature of information and information products and services. Closely linked, therefore, to these difficulties is the integration of information into existing knowledge bases, either individual or collective. The dissemination and diffusion of information and knowledge cause severe constraints for measurement. Larsen ${ }^{25}$ discusses, at some length, alternative forms of 
knowledge utilization and studies attempting to analyze knowledge utilization in different environments. She also introduces the notion of waves, or cycles, of utilization.

The remaining measurement problems result from the subjective characteristics of value and the viewpoint from which the measurement is determined. As mentioned before, one approach to determining the value of information and derived products and services is in terms of the time saved by researchers and their willingness to pay. This relies on the ability of researchers to accurately assess the value of information to themselves (and sometimes to their organization). Flowerdew and Whitehead ${ }^{10}$ define the problems associated with estimating the value of information services to a researcher's employer. First, there is the problem of overlap between the researcher's and the employer's values. The second difficulty lies in assessing the value of the researcher's time, particularly if substitute services or activities are available.

The willingness to purchase an information service at a particular price should be used cautiously because it reveals only that the purchaser values the information at that price or more: the price may not, therefore, measure the full benefit received by the purchaser (ignoring higher order effects or externalities). In order to measure this economic benefit it is the maximum sum the purchaser would pay that is required.

The final problem area alluded to several times in the literature is that of determining from which perspective to measure value-from that of the individual, the organization, or society at large. Problems of overvaluing or undervaluing are apparent, and some attempts to compensate for this were made by Hawgood and Morley. ${ }^{12}$

\subsection{GENERAL APPROACH TO MEASURING THE VALUE OF INFORMATION PRODUCTS AND SERVICES}

The purpose of this study is to assess the government information system that serves the Department of Energy funded Research and Development community.* In particular, we have attempted to assess the value of the TIC Energy Data Base, components of the EDB, and its related information products and services. In addition, we looked at the effect

* Recognizing that the non-DOE-funded energy research community might also use energy information generated from DOE funding. various public and private sector arrangements, price changes, and constraints to the free flow of information might have on the value of the information. This assessment of value is one of the first attempts to actually measure the value of information and the value added by information products and services. Data leading to the assessment were pieced together from a large number of previous studies and from several small surveys that were conducted to confirm (or deny) critical results found from the previous studies.

Value of information and information products and services can be measured from the viewpoint of several participants in the information transfer process, including searchers of secondary products and services, readers of primary products and services, the organizations that fund users, and all of society that is the ultimate beneficiary of energy information. At each level are two kinds of value. The first value of information is determined by what the consumer is willing to pay, and the other is derived through use of the information. Both perspectives depend to a large degree on the extent and purposes of use of information. It is assumed that the more information is used, the greater its value. This does not mean that extensive use of information about one research result necessarily yields greater value than less-used information concerning another research result. What it does mean is that the value of any valid information is enhanced by factors that increase the amount and extent of use of the information. The paradigms used throughout this report are totally based on this assumption.

An early SATCOM report ${ }^{4}$ by the National Academy of Science suggested that the value of information is determinable from what users are willing to pay for it. In that study, it was contended that one way to assess value was to look at it from the perspective of users and that the users themselves are the best judges of the value of information employed by them. They did not directly ask users what they thought the value of information was, but rather they looked at what price users would be willing to pay for information as a means of assessing the value of information. One way to express user willingness to pay for information is to consider the relationship between price and quantities demanded as shown in Fig. 2.3. Hypothetically, there is a relationship where the number of purchases (and uses) will vary depending on the price. If the price is increased, the number of purchases will decrease and vice versa. This relationship is known as the demand curve, and one measure of value is the area under the demand curve.

In the SATCOM report, the subscription price of journals is given as an example of the price scien- 


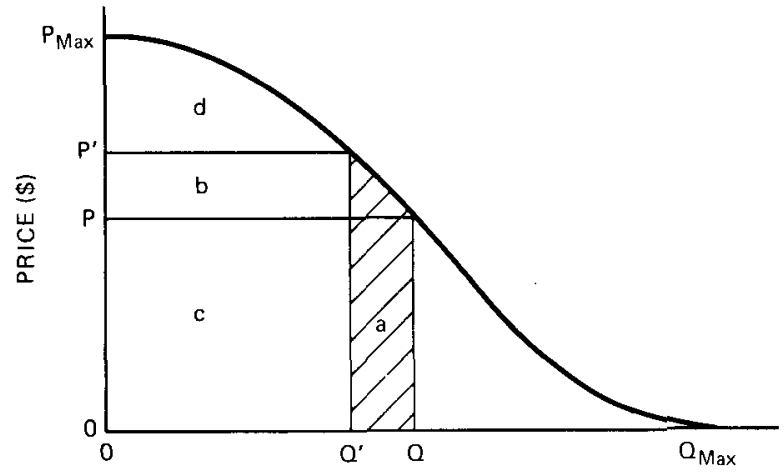

Figure 2.3 Price-and-quantities-demanded relationship with two prices.

tists and engineers are willing to pay for information. The approach is that a partial contribution to the value is the same as the self-interest value perceived by that user. If scientists and engineers are willing to pay $\$ 50$ for each journal subscription, a subscription must be at least that valuable to the individual and his work or career. Extending this to all subscriptions and scientists and engineers, one could take the existing price of journals $\left(\mathrm{P}^{\prime}\right)$ times the current quantities demanded $\left(\mathrm{Q}^{\prime}\right)$ to estimate value (area $b+c$ under the curve). However, that ignores the amount of value represented by the additional price some users would be willing to pay if they had been charged more (area $d$ under the curve). This area is called consumer surplus. It also ignores the quantities which would be demanded at lower prices if such lower prices had been charged. The total value assessed in this way could be found by integrating for the area found under the entire price-demand curve. This is what Danilov, Herring, and Hillman ${ }^{26}$ have proposed to measure value. There is one part of this economic approach to which Machlup ${ }^{1}$ and others object. They claim that a price-demand curve which ranges over all prices and all corresponding amounts of quantities demanded can only be considered hypothetical. They feel it is possible to estimate the price-andquantities-demanded relationship over small changes in price but not all potential prices. Further, the consumer surplus (area d) is misleading because such an area over all products and services would yield an impossibly high amount of value. Thus, it would be imprudent (if not impossible) to compute total value in this way. We have provided a compromise below to help address this objection.

Even though we cannot measure the price-andquantities-demanded relationship over all levels of price, one can hypothesize what effect changes in price might have on value. For example, if the price for an existing journal subscription is $\mathbf{P}^{\prime}$, one can say that reducing that price to $P$ would have the effect of increasing the quantities demanded to $Q$. This action would result in increasing the value of the journal by the amount represented by the shaded area under the curve in Fig. 2.3. Of course, this ignores the effect represented by lower revenue and lower costs. However, the value to society can be influenced to some degree by the pricing policy adopted by journal publishers.

In further study concerning the value of information, KRI felt that the "price" users were willing to pay for information went beyond the mere price charged for products or services and that it should also include the price paid by users in terms of their time and monies exchanged associated with identifying, locating, ordering, receiving, and using the information. ${ }^{5,27}$ We refer to this "price" as being the effective price of information. In the environment in which information users are scientists and engineers (or other similar professionals for that matter), it is found that their time is a scarce resource which they control to some degree. That is, scientists and engineers must constantly make choices concerning how to employ their time while at work. It is assumed that, at the moment they decide to find information or read it, that activity is the most valuable one to them. If users are willing to expend resources to search for, acquire, and read information, they must consider the information to be at least as valuable as the expended resources.

The relationship of effective price and quantities demanded is depicted in Fig. 2.4. The effective price

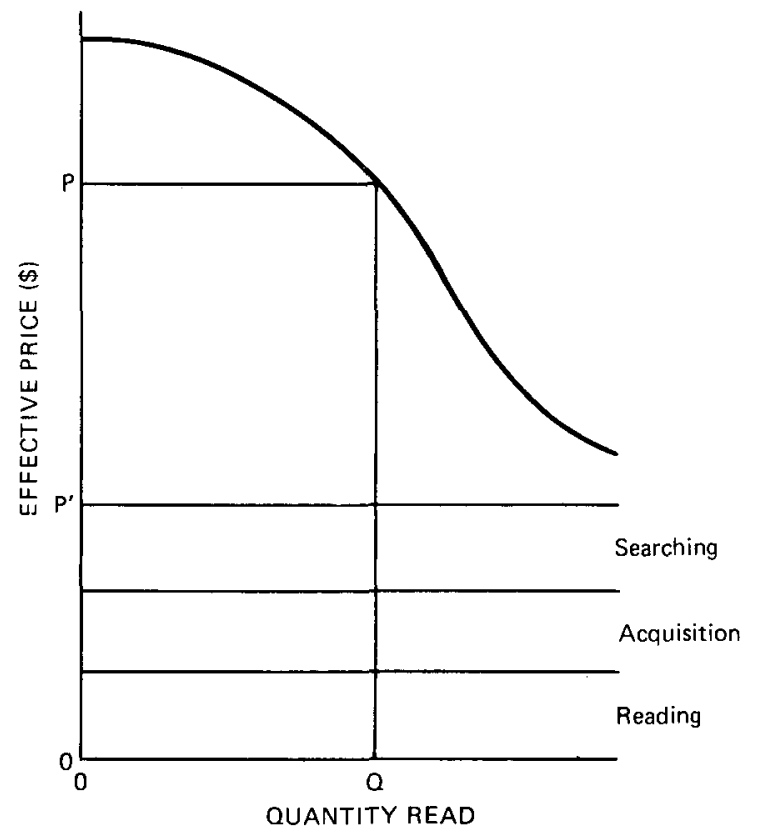

Figure 2.4 Effective price-and-quantities-demanded relationship. 
is the average dollars per reading, and the quantities of readings refer to the number of readings of a typical article or technical report. The price paid for searching, acquisition, and reading includes both monies exchanged as well as other resources. If the price charged for searching (i.e., on-line charges or price of a published index) or acquisition (i.e., subscription price for a journal or price of a paperform or microform technical report) changes, the number of items read will vary as will the values as computed by the area under the curve. It is noted that users are paying the effective price in order to assimilate information found in such media as journal articles, technical reports, patent documents, etc. The value of the information content must be distinguished from the value of information products or services themselves.

The value of an existing information system can be measured by multiplying the effective price times the number of times information is read (used). This is considered a lower bound of value because it does not include the value represented by what users would be willing to pay, but were not required to (i.e., the area of the price demand curve above the rectangle which is consumer surplus). Furthermore, this lower bound of value does not include the value derived from reading information. We have established that reading is done largely for the purposes of applying the results for conducting research, educating oneself, educating others, writing, management, etc. Each of these purposes should yield some benefits, such as saving research time and materials. Thus, additional value should be achieved through improved research results, education, writing, and management.

Considered from the viewpoint of the funders of energy scientists and engineers, the value measured in terms of user's willingness to pay may be considered an input perspective. Another perspective is how the reading and use of information affects their work. Manifestations of the value of reading information are in the labor time saved; materials, equipment, travel, supplies, telephone calls, etc. saved; improved research and development activities; improved education of oneself and others; improved decision making; and so on. This might be thought of as the process perspective. A third perspective involves how the work of scientists or engineers affects the objectives of their organizations or the goals and mission of their funders. Examples of such value might be how the work results in reducing energy consumption, increasing energy efficiency, improving balance of trade, improving quality of life, educating future scientists and engineers, improving the research and technology in other disciplines (through technology transfer), protecting sensitive information, and so on. Following the input and process perspective, this would be the output perspective. The degree of difficulty in quantifying and measuring value is less with the input perspective, greater with the process perspective, and very difficult with the output perspective.

Information is somewhat unusual in that it is purchased or acquired prior to knowledge of its information content or its potential use. For example, bibliographic searches are performed on the assumption that relevant items will be identified and read. Individuals and libraries subscribe to journals with little knowledge as to what their contents will be except by past experience. Even colleague references or citations to books, articles, or technical reports are based on hearsay. Therefore, we refer to the price paid for information as being the apparent value of information. It is noted that we consider the price paid to include monies exchanged (e.g., subscription price) as well as the time and effort expended by the user. The beneficial consequences of purchasing or otherwise acquiring information cannot be achieved except through its use. Such consequences might be in making a new discovery, saving research time and effort, and so on. Presumably, there are benefits (as well as detriments) associated with such consequences. Benefits which can be quantified in monetary units are referred to as value. We call these measurable higher order effects the consequential value of information. Then there is value associated with secondary products and services. Such value is measured by the effect a product or service has on purchasing or acquiring primary information. One can determine this effect by dropping (or simulating the nonexistence of) the product or service and observing (predicting) the consequences in terms of acquisition, use, and higher order consequences. This process can be carried out both for primary and for secondary and primary information products and services.

All of the measures of value identified presumably increase with greater frequency of use of the information. Thus, factors that lead to increased use of information enhance the value of the information. Such factors include lowering the effective price of information which includes reducing the charge for information products or services as well as reducing the cost to the user of employing them; providing better information products or services; increasing awareness of the information and means of getting it; or eliminating constraints on availability of information (i.e., security classification, transborder flow, restrictions through ownership of intellectual property, etc.).

There are other factors as well which affect value of information. For example, primary informa- 
tion is used only if the products or services employed to transfer it are purchased (or otherwise acquired) and used. The extent to which journals or technical reports, for example, are purchased depends on a number of factors, such as price; quality of information content, graphics, format, etc.; performance, such as speed of delivery and currency; and awareness of the existence of the journal articles and technical reports. Awareness can come in many ways, such as advertising, word of mouth, citations, just browsing, and searching bibliographic products and services, to name a few. Similarly, use of secondary information comes only after purchase or acquisition of secondary products and services, which in turn depends on price, performance, quality, and awareness.

The relationships above are shown in Fig. 2.5, where statements of relationships are positive ones for illustrative purposes. For example, lowering effective price, increasing quality, improving performance or increasing awareness of a product or service should increase purchases (or acquisitions). Of course, subscribing to a journal does not necessarily mean it will be read. However, considering all subscribers one would expect an increased number of subscriptions will yield an increased number of readings and use of primary information. Information is used for many purposes such as education of oneself and others, research, and management. Presumably each activity will be improved through greater use and ultimately will help the nation by improving productivity, balance of trade, use of energy resources, quality of life, and so on.

It is noted that, in order to determine the effect product or service attributes have on value, all the attributes should be considered simultaneously such as in a trade-off model or disaggregated model. Otherwise, by substituting or modifying the attributes one at a time the sum of the value of the products or services would undoubtedly exceed the total apparent value of the information handled by the products or services.

Energy information is found in several kinds of documents, such as journal articles, technical reports, books, patent documents, numeric data bases, etc. In this study, we concentrated on the information found in journal articles and technical reports. For each, we estimated the current (1981) effective price and amount of reading done by DOE-funded scientists and engineers. The effective price was estimated by computing user expenditures related to searching (i.e., through on-line search, use of published bibliographies, browsing, etc.), acquiring the journal articles and technical reports (i.e., through personal subscriptions or purchases, libraries, colleagues, etc.), and reading. The expendi- tures include all the labor time involved, prices paid, and costs of materials and equipment employed. These cost data were found through secondary sources (i.e., previous studies performed by KRI and others). The extent of reading of journal articles and technical reports was estimated from surveys conducted by KRI where amount of reading is associated with the various methods of search and acquisition.

From these data, the apparent value to the searcher of using secondary energy information products and services was calculated, and also the apparent value to the reader of using primary information products and services. The latter can also be seen as the consequential value of searching, or a measure of the effect of searching. Finally, from readers' assessments of savings from reading a journal article or report, we estimated the consequential value to the reader's organization. This estimate of value can also be considered as a return on the investment represented by the apparent value.

The determination of value of a specific information product or service was found directly and then by estimating the cost of substitute products or services. For example, the value of RECON was estimated by determining what the cost and likelihood are of various substitute methods of searching for journal articles and technical reports now found by the 70,000 annual searches conducted by RECON. Where available, both manual and on-line substitutes were identified. In all instances where substitute on-line searches are involved, the costs to users are higher because the search rates are higher. Furthermore, sometimes the searches must be conducted across two or more data bases. Since users are required to employ more expensive on-line searches, it is assumed that some users may switch to manual searching because it is less expensive when a small number of searches are performed in a library. The extent to which this might occur is based strictly on economic costs which are estimated and converted to the alternative substitutes.

Estimates are made for the cost of searching by means of substitute search methods where the least expensive substitute is always assumed to be employed by users. This is a conservative assumption; using a more expensive substitute would increase the estimate of value obtained. A further assumption is made that the total cost of searching of all users will remain about the same regardless of whether RECON or substitute search methods are used. Thus, since the substitute search methods cost more, fewer searches would be performed and fewer readings would take place. The number of searches that can be performed under the substitute methods at the total cost is found by dividing the total 


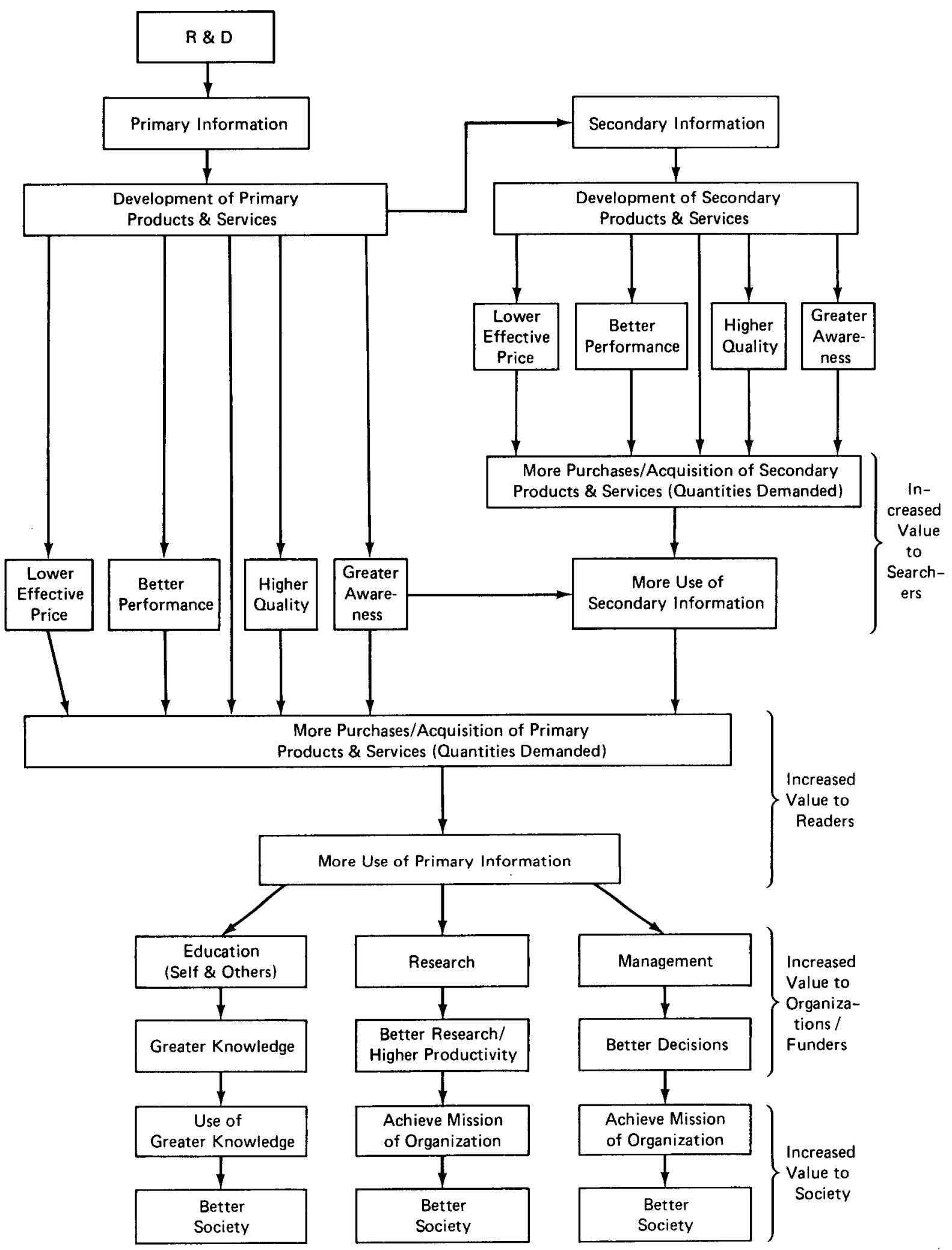

Figure 2.5 Factors related to increasing value of information. 
RECON search costs by the average cost of searching by the substitute methods. The number of searches lost and, hence, readings denied to users by not having RECON is computed.

Another way of looking at employing substitute searches is that a higher priced substitute service is like increasing the price of on-line searching. This, of course, assumes that other attributes (such as response time or search characteristics) remain the same. The advantage of this approach is that it overcomes much of the objection raised by Machlup ${ }^{1}$ and others concerning the consumer surplus area under the price-and-quantities-demanded curve. Referring back to the curve for the relationship between effective price and quantities demanded, we have a hypothetical plot given in Fig. 2.3. The current situation has an effective price and quantities demanded given by $P$ and $Q$. Here we give the RECON on-line search service as an example. The effective price would include only search activities. Again, it is assumed that the total search costs remain constant (i.e., area $a+c$ ). The difference in substitute effective price is $P^{\prime}$ minus $P$. One then moves $Q$ (number of searches performed under the substitute services) to the left to the point where the area of the substitute services $(b+c)$ equals the original area $(a+c)$. Thus, area $(a)$ equals area (b). One estimate of the value of RECON then can be calculated by the shaded area under the curve between quantities demanded $Q^{\prime}$ and $Q$. However, the question becomes one of how the reduced number of searches affects (1) the amount of reading, (2) the work of the scientists or engineers, and (3) the objectives of the organization or the goals and mission of DOE.

The number of readings per search is estimated by observation. Thus, if fewer searches are performed, one can calculate the comparable number of readings lost because a substitute search method was employed. From this we could estimate value computed by the change in user's willingness (necessity) to pay higher effective prices. We also asked readers to indicate whether a specific reading of an article or technical report yielded a savings in labor time (of any of the staff), equipment, or supplies. This estimate of savings is, in effect, an indication of improved productivity yielded by reading. From these estimates, we computed the total amount of savings lost because substitute search services would be employed. These estimates provide a conservative estimate of the value derived from savings yielded by readings resulting from RECON searches performed under existing prices. It is a conservative estimate because other benefits must also accrue. This analysis was performed for both RECON and the collective EDB services, including EDB searching via RECON and other services, searching of EDB-based records in the NTIS Bibliographic Data File, and searching of Energy Research Abstracts and other TIC-printed indexes. 


\section{CHAPTER 3}

\section{ESTIMATING VALUE}

This chapter provides details of the procedures followed and the data obtained in carrying out our approach to the measurement of the value of the EDB. The first section includes background data on reading by energy scientists and engineers in general and by DOE-funded scientists and engineers specifically. Next, in Section 3.2, the costs associated with searching and reading articles and reports are derived, both for the current activities and for substitute activities. Section 3.3 describes the process of identifying substitutes for EDB services and calculating their associated costs. Estimates of value at various levels are derived in Section 3.4, and a discussion of the application of the value concept is in Section 3.5.

\subsection{AMOUNT OF SEARCHING AND READING BY ENERGY SCIENTISTS}

In this section, data are presented on reading by energy scientists and engineers in general and by DOE-funded scientists and engineers in particular. A large number of studies over the past twenty years ${ }^{5}$ have clearly demonstrated the enormous amount of reading and time spent reading by scientists and engineers. This reading involves journal articles, books, and technical reports as well as other kinds of written materials. In a survey conducted by King Research, Inc. (KRI) for the National Science Foundation, it was estimated that the average number of articles read per month by scientists and engineers (who indicated they were engaged in research and development, including actual performance of $R \& D$ as well as related management, teaching, etc.) was about 8.7 articles read per month with an average of about 6.8 hours per month spent reading these articles. The extent of reading varies somewhat among the fields of science as shown in Table 3.1. The total number of readings in one year for all U.S. scientists and engineers was estimated to be 245 million, and total amount of time spent reading was about 185 million hours.
Table 3.1 ESTIMATED AVERAGE NUMBER OF JOURNAL ARTICLES READ PER MONTH AND TIME SPENT READING PER MONTH BY SCIENTISTS AND ENGINEERS IN THE U.S.: $1977^{*}$

\begin{tabular}{lcc}
\hline Field of science & $\begin{array}{c}\text { No. of } \\
\text { articles read } \\
\text { per month }\end{array}$ & $\begin{array}{c}\text { Hours per } \\
\text { month spent } \\
\text { reading articles }\end{array}$ \\
\hline Physical sciences & 15.8 & 9.0 \\
Mathematics & 5.1 & 19.1 \\
Computer sciences & 5.6 & 3.4 \\
Environmental & & \\
$\quad$ sciences & 9.0 & 4.2 \\
Engineering & 6.4 & 5.0 \\
Life sciences & 15.0 & 8.1 \\
Psychology & 8.9 & 4.8 \\
Social sciences & 10.4 & 11.3 \\
Other sciences & 6.3 & 7.2 \\
$\quad$ All fields & 8.7 & 6.8 \\
\hline
\end{tabular}

*Source: King Research, Inc.

Substantial evidence from other studies seems to corroborate these data showing the importance of journal reading. Across a number of other studies, it was estimated that the average hours per month spent reading journal articles ranged from a low of 2.2 hours per month for engineers up to 25.1 hours per month for physical scientists. The amount of time spent reading all literature ranged from 8.6 hours per month for engineers to 36.8 hours per month for the physical scientists. Part of the reason for the variability among studies was the definition of reading. Reading in the KRI survey meant going beyond the contents, title, and abstract to the body of the article. Regardless of definition, these studies confirm that there is a great deal of time spent by scientists and engineers in reading. These results are shown to hold true for energy scientists and 
engineers as well. In the next subsection, we give some estimates for the amount of reading by DOEfunded scientists and engineers.

\subsubsection{EXTENT OF READING AND OTHER INFORMATION ACTIVITIES OF ENERGY SCIENTISTS AND ENGINEERS}

The number of U.S. energy scientists and engineers engaged in research and development activities funded by the Department of Energy is estimated at 60,000 in 1981 . This number was derived from an estimate of $\$ 5.8$ billion expended by DOE on $R \& D$ and average $R \& D$ expenditures per scientist and engineer over all fields of science of $\$ 97,000$. The estimated total R\&D funding for all fields of science in 1981 was $\$ 66$ billion, and the number of scientists and engineers involved was about 680,000 . Thus the 60,000 DOE-funded energy scientists and engineers make up about 9 percent of the total scientific R\&D population. DOE-funded energy research makes up the vast majority of Federally funded energy research.

From the 2,300 responses of scientists and engineers received from the KRI survey described earlier, 148 responses that were considered to be from energy scientists and engineers were culled out. The selection of the 148 was based on a combination of the title of an article that they authored and/or the title of the journal which published the article they last read. Of the 148 energy respondents, 60 were physical scientists; 11 mathematicians, statisticians, or computer scientists; 34 environmental scientists; 30 engineers; 10 life scientists; 2 social scientists; and one other scientist.

In the same survey, it was estimated that the energy scientists and engineers received most of their funding from the Government. In fact, 70 percent of the respondents indicated that the Government supplied the largest portion of funds for their current projects. From 1981 estimates of energy R\&D funding, the Government is estimated to provide 75 percent of the funding. Thus, there appears to be little, if any, bias in the sample of 148 from the standpoint of sources of funds. Other demographics of the respondents include primary employer: 62 percent university, 15 percent government, and 23 percent profit and nonprofit institutions. The work categories in which the respondents spent the largest proportion of time were research $(76 \%)$, teaching $(11 \%)$, management $(8 \%)$ and other (5\%). It is not known if these proportions of demographic categories are representative.

Based on the responses from energy scientists and engineers, it is estimated that the average number of articles read per month is 12.2 , and the average amount of time spent reading these articles is 12.3 hours (or about one hour per reading). For the last article read, 41 percent of the scientists or engineers indicated they read it with great care, 51 percent with attention to the main points, and 8 percent just to get the idea. In about one half of the readings, the respondents indicated they did not know about the research reported (or reviewed) prior to reading the article. The total amount of reading of articles by the estimated 80,000 energy scientists and engineers engaged in $R \& D$ is estimated to be 10 million articles, accounting for about 10 million hours of their time in 1981. In order to verify some of these estimates, we conducted some small surveys of DOE-funded scientists and engineers.* In those surveys, the average number of articles read per month was 9.8 articles (compared to 12.2 from the NSF survey) and the amount of time spent reading articles was 9.8 hours (compared to 12.3 hours). Thus, the DOE-funded scientists and engineers appear to read at about the same level as energy scientists and engineers. Total reading for the 60,000 DOE-funded scientists and engineers is 7.1 million articles.

Energy scientists and engineers differ some from other scientists and engineers in their methods of identifying the articles read and the means used to get these articles. Energy scientists and engineers subscribe personally to fewer publications than persons from other fields of science (3.1 personal subscriptions vs. 10.2 personal subscriptions for all scientists and engineers). For that reason, a higher proportion of readings by energy scientists and engineers takes place from library copies of journals (46\%) than others (14\%). This also means that energy scientists and engineers read older articles on the average ( 2.7 years vs. 1.3 years). The energy scientists find a similar proportion of articles read through bibliographic products and services compared with other scientists $(25 \%$ vs. $24 \%)$. It is estimated that energy scientists and engineers make about 6.5 on-line bibliographic searches per year, about one fourth of which they conduct themselves with the remainder conducted by an intermediary. They average about 3.2 hours spent on each search for performing the search (or discussing the search with an intermediary) and examining the output. It is noted that energy scientists and engineers also use computerized numeric data bases extensively, on the average about 12.8 times per year. This area of information activity is not taken into account in later estimates in this report of time spent using the energy literature.

*See Appendix A for discussion of survey methodology. 
As mentioned above, the total amount of reading by the 60,000 DOE-funded scientists and engineers is estimated to be about 7.1 million readings of articles per year. In the small DOE user surveys, we asked DOE-funded scientists and engineers about their amount of article and technical report reading and the time spent reading each, respectively. Using the reported relationship of the two, there would be about 6.6 million readings of technical reports by DOE-funded scientists and engineers. The amount of time spent reading technical reports is estimated to be 13.8 hours per month on the average for reading 9.2 technical reports. In another study that obtained similar data, ${ }^{28}$ it was estimated that biomedical professionals spent an average of 7.6 hours reading articles and 19.7 hours reading technical reports per month (compared to 9.2 hours and 13.8 hours, respectively, for energy scientists and engineers). Thus, the amount seems reasonable by comparison. It is noted that the number of technical reports read by DOE-funded scientists and engineers is not necessarily all technical reports generated under DOE funding. Some of them may be internal technical reports or those generated through other agency funding.

Rough computations are also made by other methods for estimating the amount of reading of technical reports generated under DOE funding. Copies of these reports are made available through TIC standard paper and standard microfiche distribution as well as through on-demand distribution. It is assumed that most, but not all, of the readings from these channels are by DOE-funded scientists and engineers. Also, technical reports generated under DOE funding are made available from the National Technical Information Service (NTIS). Summaries of rough estimates of the extent of reading are given in Table 3.2.

The total estimated number of readings of energy technical reports comes to 6.8 million, of which an estimated 6.2 million come from TIC distribution and 0.6 million from NTIS distribution. Overall, there are 6.2 million report copies distributed, so that there were on the average about 1.1 readings per copy distributed.

Estimates of TIC and NTIS distribution come from records of the respective organizations. As shown, 4.9 million copies, or nearly 80 percent of the total, are sent out from TIC on standard distribution. These copies account for about 70 percent of the estimated report uses. Estimates of report use come from several sources. The estimate of the amount of reading from TIC standard distribution in paper form comes from a small survey of distribution points in which respondents were asked to indicate the extent of reading of these copies. Results, when projected to the entire number of access points, come to 3.4 million. This would suggest that individual copies distributed are read an average of about 1.6 times. Estimates of reading from report copies distributed on demand are based on a conservative estimate of two readings per copy ordered (the original requestor plus one other). Estimates of reading of microfiche copies are based on findings from the surveys of energy scientists which indicate that the total number of fiche readings is about 30

Table 3.2 ESTIMATES OF DISTRIBUTION AND READERSHIP OF TECHNICAL REPORTS GENERATED UNDER DOE FUNDING: 1981*

\begin{tabular}{lccc}
\hline $\begin{array}{c}\text { Distribution } \\
\text { channel }\end{array}$ & $\begin{array}{c}\text { No. of } \\
\text { titles }\end{array}$ & $\begin{array}{c}\text { Copies distributed, } \\
\text { in millions }\end{array}$ & $\begin{array}{c}\text { Readings, } \\
\text { in millions }\end{array}$ \\
\hline TIC & & 2.1 & 3.4 \\
Standard (paper) & 8,300 & 2.8 & 1.4 \\
$\begin{array}{l}\text { Standard (fiche) } \\
\text { On-demand }\end{array}$ & 25,300 & $\underline{0.7}$ & $\underline{1.4}$ \\
$\quad 25,300$ & 5.6 & 6.2 \\
$\quad$ Total TIC & & 0.4 & 0.2 \\
NTIS & 15,000 & $\underline{0.2}$ & $\underline{0.4}$ \\
Standard (fiche) & & 0.6 & 0.6 \\
On-demand & 15,000 & $\overline{6.2}$ & 6.8 \\
$\quad$ Total NTIS & & & \\
Total & & &
\end{tabular}

*Source: King Research, Inc. 
Table 3.3 READINGS PER MONTH AND TOTAL READINGS OF ARTICLES AND REPORTS BY DOE-FUNDED SCIENTISTS AND ENGINEERS IN FIVE PROGRAM AREAS: 1981*

\begin{tabular}{|c|c|c|c|c|c|c|c|}
\hline & \multicolumn{6}{|c|}{ Program area } & \multirow[b]{2}{*}{ Totalt } \\
\hline & Defense & Nuclear & $\begin{array}{l}\text { Basic energy } \\
\text { science }\end{array}$ & Fusion & $\begin{array}{l}\text { Health and } \\
\text { environment }\end{array}$ & $\begin{array}{c}\text { All } \\
\text { other }\end{array}$ & \\
\hline \multicolumn{8}{|l|}{ Article readings } \\
\hline Per scientist per month & 9.2 & 10.7 & 8.9 & 11.7 & 10.0 & 10.0 & 9.8 \\
\hline Total (millions) & 1.36 & 1.05 & 0.82 & 0.50 & 0.25 & 3.12 & 7.1 \\
\hline \multicolumn{8}{|l|}{ Report readings } \\
\hline Per scientist per month & 7.8 & 11.7 & 8.6 & 11.3 & 7.2 & 9.1 & 9.2 \\
\hline Total (millions) & 1.15 & 1.16 & 0.79 & 0.49 & 0.18 & 2.83 & 6.6 \\
\hline \multicolumn{8}{|l|}{ Total readings } \\
\hline Per scientist per month & 17.0 & 22.4 & 17.5 & 23.0 & 17.2 & 19.1 & 19.0 \\
\hline Total (millions) & 2.51 & 2.21 & 1.61 & 0.99 & 0.43 & 5.95 & 13.7 \\
\hline
\end{tabular}

*Source: King Research, Inc.

$\dagger$ The per scientist per month total is an average calculated by dividing total readings by total number of scientists by 12 months.

percent of the number of paper copy readings. Since there are 5.2 million paper copy readings, there would be an estimated 1.6 million readings from fiche, or 0.5 readings per copy distributed. This is higher than, but not out of line with, results for standard distribution microfiche in the education area (distributed by the Educational Resources Information Center) which have been found to be read at a rate of 0.3 per copy distributed.

Data obtained on the amount of reading can be broken down according to the major program areas in energy research, based on categorizing survey responses according to the scientist's or engineer's source of funding. For this study, we looked at five major program areas and subareas: defense, nuclear science, and basic research which in turn was divided into basic energy sciences, fusion, and health and environmental research. The number of scientists in each of these areas was estimated from research funding, and survey results from each program area were considered separately. In total, scientists in these areas account for about 60 percent of all DOE-funded scientists and engineers.

Results of the analyses by program show some differences among the various areas. Readings per month and total readings are shown in Table 3.3. As indicated, reading levels are somewhat higher in the areas of nuclear science and fusion. Tables by program area showing research funding and numbers of scientists and also other data items are included in Appendix B of this report.

The methods employed by energy scientists and engineers to identify articles and reports read were also determined in our surveys. The proportion of readings resulting from various methods of identification is given in Table 3.4. These results are repeated for the five program areas considered in Appendix B.

Table 3.4 METHODS OF IDENTIFYING ARTICLES AND TECHNICAL REPORTS READ BY ENERGY SCIENTISTS AND ENGINEERS: 1978, 1981

\begin{tabular}{lcc}
\hline \multicolumn{1}{c}{$\begin{array}{c}\text { Method of } \\
\text { identification }\end{array}$} & Articles, \%* & Technical reports, \% ${ }^{\dagger}$ \\
\hline While browsing/distribution copy & 42 & 52 \\
From another person (i.e., a colleague) & 18 & 24 \\
Cited in another article/report & 15 & 8 \\
Cited in a printed index & 7 & 16 \\
In the output of a computerized literature & 18 & 12 \\
$\quad$ search & 18 & \\
\hline
\end{tabular}

*Source: King Research, Inc. ${ }^{5}$

$\dagger$ King Research, Inc., surveys of DOE-funded scientists and engineers. 


\section{Table 3.5 ESTIMATED NUMBER OF READINGS OF ARTICLES AND TECHNICAL REPORTS IDENTIFIED BY ON-LINE SEARCHES BY DOE- FUNDED SCIENTISTS AND ENGINEERS BY DATA BASE: 1981*}

\begin{tabular}{|c|c|c|c|c|}
\hline \multirow[b]{2}{*}{ Data base } & \multirow{2}{*}{$\begin{array}{l}\text { Scientist's or engineer's } \\
\text { facility }\end{array}$} & \multirow{2}{*}{$\begin{array}{l}\text { No. of on-line } \\
\text { searches, } \\
\text { in thousands }\end{array}$} & \multicolumn{2}{|c|}{$\begin{array}{l}\text { No. of readings, } \\
\text { in thousands }\end{array}$} \\
\hline & & & Articles & Reports \\
\hline EDB via $\mathrm{RECON}$ & 417 RECON users & 70 & 602 & 440 \\
\hline NTIS & 2,000 DOE-funded & 40 & - & 610 \\
\hline Others & 2,000 DOE-funded & 64 & 958 & - \\
\hline Total & & 174 & 1,560 & 1,050 \\
\hline
\end{tabular}

*Source: King Research, Inc.

Both articles and reports are most frequently found through distribution of a copy to the individual scientist or engineer, or possibly their libraries. For journal articles, energy scientists and engineers receive on the average three individual subscriptions and browse through these to identify articles to read. Two percent of report readings were attributed to browsing and another 50 percent to the similar activity of receiving a distribution copy (assumed to be TIC or NTIS standard distribution). In other methods of identification, there is a somewhat greater proportion of articles found through citation $(15 \%)$ as compared with reports $(8 \%)$. Bibliographic products, printed indexes, and on-line data bases are used for 25 percent of article readings and 28 percent of report readings. Identification by a colleague accounts for 18 percent of article readings and 24 percent of report readings. In later calculations it is assumed that colleague references in turn come through the other identification methods, and so access through these other methods is increased proportionately.

Of particular interest in this study is the use of bibliographic products in accessing energy articles and reports. Estimates of the number of readings resulting from such use are shown below, along with estimates of the number of searches conducted. Distinctions are also made between the different bibliographic products and services used by energy scientists and engineers.

In developing these estimates, we distinguished between two types of organizations or libraries providing information services to energy scientists and engineers: 417 RECON organizations and 1,583 other DOE-funded organizations. The 417 institutions with RECON access generally serve more DOE-funded researchers and thus have more reading associated with their use. In our surveys, data were collected from both institutions with RECON and other libraries, but to a disproportionate extent from the former.

Table 3.5 gives estimates of the number of online searches and resulting amount of reading in the two types of facilities. Also distinguished are the data bases searched: the Energy Data Base (EDB) via RECON; the NTIS Bibliographic Data File, which contains EDB records; and other data bases. For 1981, there was also a small volume of searching of the EDB via Bibliographic Retrieval Services (BRS) which is not reflected in the table.

Estimates of the amount of reading resulting from data base searches were obtained from the surveys of energy scientists and engineers and their libraries. On the average, scientists and engineers reported 14.9 readings per RECON search, including 8.6 article readings and 6.3 report readings. It should be noted that this is the number of readings, not items identified; the number of citations obtained from the search is equal to or more frequently larger than the number of items actually read. Readings resulting from NTIS searches are estimated at 15 (all reports) and readings from other data base searches also at 15. The latter is assumed to be predominantly articles.

From TIC records, it is known that there were approximately 70,000 RECON searches in 1981. As shown in Table 3.5, these searches account for 602,000 article readings and 440,000 report readings. The total number of article readings through on-line searches, estimated from Table 3.4, is $1,560,000$. It is assumed that the 958,000 of these readings which are not from RECON searches are from 64,000 other data base searches. Similarly, the total number of report readings from on-line searches is $1,050,000 ; 440,000$ from RECON searches and 610,000 from 40,000 searches of other data bases. 
Table 3.6 indicates the numbers of printed index searches and associated readings by DOE-funded scientists and engineers. Again, total readings are derived from Table 3.4 and include 640,000 article readings and 1,390,000 report readings. An ERA search is assumed, based on survey data, to result in 5.7 report readings and 0.8 article readings on the average. Thus, we estimate that there were about 244,000 searches of ERA. The remaining article

Table 3.6 ESTIMATED NUMBER OF READINGS OF ARTICLES AND TECHNICAL REPORTS IDENTIFIED BY PRINTED INDEX SEARCHES BY DOE-FUNDED SCIENTISTS AND ENGINEERS BY INDEX: 1981*

\begin{tabular}{|c|c|c|c|}
\hline \multirow[b]{2}{*}{ Index } & \multirow{2}{*}{$\begin{array}{c}\text { No. of } \\
\text { searches, in } \\
\text { thousands }\end{array}$} & \multicolumn{2}{|c|}{$\begin{array}{l}\text { No. of readings, } \\
\text { in thousands }\end{array}$} \\
\hline & & Articles & Reports \\
\hline \multicolumn{4}{|l|}{$E R A$ and other } \\
\hline TIC indexes & 244 & 195 & 1,390 \\
\hline Other indexes & 78 & 445 & - \\
\hline Total & 322 & 640 & 1,390 \\
\hline
\end{tabular}

*Source: King Research, Inc. readings are assumed to come from 78,000 other index searches each resulting in 5.7 readings.

For later use, Table 3.7 summarizes the number of report and article readings by DOE-funded scientists and engineers through various means. This analysis was repeated for each of the major program areas considered in this project, with results shown in Appendix B.

\subsection{EFFECTIVE PRICE OF SEARCHING AND OF READING ARTICLES AND REPORTS}

Our method of estimating the apparent value of searching and of reading depends on the volume of each of these activities, as estimated in the preceding section, and the costs associated with them. This section discusses the derivation of estimates of search costs and the costs of reading both articles and books. In looking at search costs, both current costs and the costs of possible alternatives are considered. Reading costs are developed for the current system and the current mix of identification and access methods. These costs are combined appropriately into overall average effective prices for reports and articles which it is assumed would remain approximately the same under the alternative situations envisioned.

Table 3.7 ESTIMATED NUMBER OF READINGS OF ARTICLES AND TECHNICAL REPORTS IDENTIFIED BY VARIOUS METHODS BY DOE-FUNDED SCIENTISTS AND ENGINEERS: 1981*

\begin{tabular}{|c|c|c|c|}
\hline \multirow{2}{*}{$\begin{array}{l}\text { Identification } \\
\text { method }\end{array}$} & \multirow{2}{*}{$\begin{array}{l}\text { No. of } \\
\text { searches, in } \\
\text { thousands }\end{array}$} & \multicolumn{2}{|c|}{$\begin{array}{l}\text { No. of readings, } \\
\text { in thousands }\end{array}$} \\
\hline & & Articles & Reports \\
\hline \multicolumn{4}{|l|}{ On-line search } \\
\hline EDB via RECON & 70 & 602 & 440 \\
\hline NTIS & 40 & - & 610 \\
\hline Others & 64 & 958 & - \\
\hline Subtotal & 174 & 1,560 & 1,050 \\
\hline \multicolumn{4}{|l|}{ Printed index } \\
\hline$E R A$ and other TIC indexes & 244 & 195 & 1,390 \\
\hline Others & 78 & 445 & - \\
\hline Subtotal & 322 & 640 & 1,390 \\
\hline Nonbibliographic & - & 4,900 & 4,160 \\
\hline Total & 496 & 7,100 & 6,600 \\
\hline
\end{tabular}

*Source: King Research, Inc. 


\subsubsection{SEARCH COSTS}

A detailed derivation of search costs is given in Appendix C. This derivation takes into account detailed estimates of time and other cost factors for the institutions conducting searches. Estimates are derived for manual searching of $E R A$ and other printed indexes for both quick and hard searches. For on-line searching, costs are developed for searching of the EDB via RECON, of the NTIS Bibliographic Data File, of other on-line data bases, and of substitute on-line data bases. The calculation of substitutes is based on that combination of data bases necessary to approximate the coverage of the EDB relative to a particular search. Results of the cost models for searching are summarized in Table 3.8.

Fixed costs per library include such items as subscription costs, terminal purchase or rental, telephone rental, and searcher training. These are incurred regardless of the number of searches. Per search costs include labor, communication charges, and data base use charges. As outlined in Appendix $\mathrm{C}$, selecting among the search alternatives requires consideration of the number of searches to be conducted and both the fixed costs and per search costs. In comparing use of the EDB searched via RECON with other printed index searching, for example, per search costs are higher for the EDB but fixed costs are lower. At low volumes of searching, RECON will be less expensive but at high volumes, the use of other printed indexes will be preferable. The breakeven point in this case is 2400 searches per year; that is, if fewer than 2400 searches are conducted, a RECON search will be less costly than another printed index search.

Table 3.8 also gives the number of readings per search and the resulting per reading cost. The search cost per reading is introduced because we are ultimately interested in the cost per reading, and the number of readings associated with different types of searches is different. Thus, in considering alternatives, we actually looked at fixed costs and per reading search costs in making decisions.

Two situations are considered in later analyses; first, searching without any EDB products and services, and second, searching without RECON. In the first case, the EDB via RECON, NTIS, and $E R A$ or other TIC indexes would not be available. Possible alternatives are substitute on-line data bases or substitute printed indexes. From the table, we see that substitute on-line data bases are less expensive in both fixed cost and per reading terms, and so this alternative would always be selected. In the second case, if only RECON were unavailable, there are more options-NTIS and $E R A$ for reports; $E R A$, substitute on-line data bases and substitute indexes for articles. NTIS is least costly on a per reading basis for reports, and substitute on-line data bases are similarly selected as an alternative means of identifying journal articles.

For the purposes of developing total search costs for effective price calculations, fixed costs and per search costs are combined. Also included are costs associated with review by the end user. The total search costs identified for the current system are $\$ 105$ per search for EDB searching via RECON,

\section{Table 3.8 COST OF SEARCHING BY VARIOUS MEANS IN DOE-FUNDED LIBRARIES: 1981*}

\begin{tabular}{lcccc}
\hline & $\begin{array}{c}\text { Fixed cost } \\
\text { per }\end{array}$ & \multicolumn{2}{c}{ Cost, $\mathbf{~}$} & Readings \\
\cline { 3 - 4 } \multicolumn{1}{c}{ Search method } & library & Per search $\dagger$ & Per reading $\ddagger$ & per search \\
\hline EDB via RECON & 4,350 & 16.80 & 1.12 & 15.0 \\
NTIS & 4,350 & 20.20 & 1.35 & 15.0 \\
Other on-line data base & 4,350 & 30.50 & 2.03 & 15.0 \\
Substitute on-line data base & 8,250 & 101.90 & 6.80 & 15.0 \\
ERA or other TIC index & 1,552 & 13.80 & 2.12 & 6.5 \\
Other printed index & 11,580 & 13.80 & 2.42 & 5.7 \\
Substitute printed index & 11,580 & 58.10 & 10.19 & 5.7 \\
\hline
\end{tabular}

*Source: King Research, Inc.

†Quick and hard searches combined. For on-line searches, 41 percent quick and 59 percent hard were assumed; for manual searches, 74 percent quick and 26 percent hard. $\ddagger$ Per search cost divided by number of readings resulting from search. 
$\$ 115$ per search for NTIS searching, \$203 per search for other on-line searching, $\$ 34$ per search for ERA searching and $\$ 176$ per search for other printed index searching. Per reading total search costs derived from these data are as follows:

\begin{tabular}{lc}
\hline \multicolumn{1}{c}{$\begin{array}{c}\text { Identification } \\
\text { method }\end{array}$} & $\begin{array}{c}\text { Per reading } \\
\text { search cost, } \mathbf{S}\end{array}$ \\
\hline EDB via RECON & 7.00 \\
NTIS & 7.60 \\
Other on-line data base & 13.50 \\
$E R A$ or other TIC index & 5.20 \\
Other printed index & 30.70 \\
\hline
\end{tabular}

\subsubsection{EFFECTIVE PRICE OF READING ARTICLES AND REPORTS}

The price associated with reading an article or report includes both the purchase price of the material itself and also costs associated with acquisition, identification, and with the actual reading. Each of these must be taken into account in determining effective price.

Purchase and acquisition-related costs are incurred for each article or report copy distributed, while identification and reading costs are associated with the number of readings of materials. The effective price thus depends on both the number of copies distributed and on the number of readings, and thus on the relationship between the two. Effective price is also dependent on the particular ways in which materials are acquired and identified.

Components of the effective price for reports include the purchase of reports through various channels, processing costs, the cost of identifying reports by various means, the cost of accessing reports by various means, and the cost of reading. Each of these is described briefly below. Table 3.9 summarizes the results of the calculations.

\section{Report Purchase}

Table 3.2 shows TIC and NTIS distribution of DOE reports totalling 6.2 million copies and resulting in 6.8 million readings. TIC standard distribution and most of the on-demand distribution is free, while each of the other distribution categories has associated purchase prices-on the average, $\$ 0.172$ for TIC fiche reports, $\$ 0.97$ for NTIS standard distribution, and $\$ 13.50$ for NTIS on-demand distribution. The total costs thus associated with report purchase are approximately $\$ 3.7$ million, $\$ 0.60$ per report copy or $\$ 0.60$ per report reading.

\section{Table 3.9 EFFECTIVE PRICE OF READING REPORTS*}

\begin{tabular}{lcc}
\hline & \multicolumn{2}{c}{ Cost } \\
\cline { 2 - 3 } Cost category & $\begin{array}{c}\text { Total, in } \\
\text { millions of \$ }\end{array}$ & $\begin{array}{c}\text { Per } \\
\text { reading }\end{array}$ \\
\hline Report purchase & 3.7 & $\$ 0.60$ \\
Processing & 21.7 & 3.30 \\
Identification & & \\
$\quad$ Manual search & $(7.2)$ & $(5.20)$ \\
$\quad$ On-line search & & \\
$\quad$ RECON & $(3.1)$ & $(7.00)$ \\
$\quad$ NTIS & $(4.6)$ & $(7.60)$ \\
$\quad$ Combined & $(7.7)$ & $(7.30)$ \\
$\quad$ Combined total† & 14.9 & 2.20 \\
Access & 37.0 & 5.60 \\
Reading & 166.3 & 25.20 \\
Total & 243.6 & $\$ 36.90$ \\
\hline
\end{tabular}

*Source: King Research, Inc.

$\dagger$ Includes all others at $\$ 0$ for searching per reading.

\section{Report-Processing Costs}

Most DOE reports distributed go to libraries or institutional processing centers of some type. To account for processing costs, it is estimated that all 6.2 million copies distributed are checked in at a $\operatorname{cost}^{5}$ of $\$ 3.50$. Storage costs associated with the reports are assumed minimal. The total processing cost then is $\$ 21.7$ million. Over the 6.8 million estimated report readings, this is $\$ 3.30$ per reading.

\section{Report-Identification Costs}

Table 3.4 showed the relative use of various means of identifying DOE reports, including 12 percent via a computerized search, 16 percent via a printed index, and the remaining 72 percent through some other means such as browsing, standard distribution, and so on.

Identification costs for manual searches are discussed in Appendix $\mathrm{C}$, which indicates fixed and per search costs for $E R A$ and other indexes. An estimated 244,000 searches are made in $E R A$ and 80,000 in other indexes by the 2,000 DOE-funded libraries. These searches result in both article and report readings as indicated in Table 3.7.

To calculate the costs of manual searching to obtain a report, we consider the costs associated with searching ERA and other TIC indexes and allocate these in proportion to levels of resulting report and article reading. Total fixed costs in the 2,000 libraries are $\$ 1.8$ million, with $\$ 1.6$ million allocated to reports and $\$ 0.2$ million to articles. The 
cost per report reading is $\$ 1.10$. Per search manual costs, combining costs for quick and hard searches, are $\$ 13.80$. Since a search results in 5.7 reports and 0.8 articles read, on the average, the cost per reading is taken as $\$ 2.10$. To these costs must be added the user's time spent reviewing search output, estimated at 60 minutes per search for the 75 percent of searches not done by the user. This is a total of $\$ 3.1$ million, or $\$ 2.00$ per reading overall. Adding the fixed costs to these numbers results in an estimated $\$ 5.20$ per report reading.

To calculate the costs associated with on-line searching, a similar analysis is performed using results also given in Appendix C. Here the activity of interest is 70,000 RECON searches, 40,000 NTIS searches, and 60,000 other on-line searches resulting in 1,050,000 report readings and 1,560,000 article readings in total. Fixed costs for RECON average $\$ 4,350$ in the 417 user libraries for a total of $\$ 1.8$ million. This is $\$ 1.70$ for each of the report or article readings. Per search RECON costs are $\$ 16.80$, or $\$ 1.10$ for each of the 14.9 readings (6.3 articles and 8.6 reports) which result. User review time is 2.9 hours or $\$ 48.70$ per search for 75 percent of the searches, a total of $\$ 2.6$ million. This is $\$ 2.50$ per reading. Thus, the total RECON search cost per reading is $\$ 7.00$. For NTIS searches, the fixed costs are $\$ 4,350$ for each of an estimated 540 libraries, for a total cost of $\$ 2.3$ million and a per reading cost of $\$ 3.80$. Per search and review NTIS costs are $\$ 20.20$ and $\$ 36.50$, equivalent to $\$ 3.80$ for each of the 15.0 readings per search. This makes total NTIS per reading costs $\$ 7.60$.

The cost of identifying articles by means other than on-line or manual searches is taken to be zero, or near zero. When the various costs are combined appropriately, the total cost of report identification is estimated at $\$ 14.9$ million, or $\$ 2.30$ per reading.

\section{Report-Access Costs}

Report-access costs represent time spent by the reader and library support staff physically locating a report, taking it off the shelf, and refiling it. These costs have been estimated at $\$ 5.60$ per reading ${ }^{5}$ or a total of $\$ 37.0$ million for all report readings.

\section{Report-Reading Costs}

Report-reading-cost estimates are based on an average time of 90 minutes per report and an average salary of $\$ 16.80$ per hour. This totals $\$ 25.20$ per reading or $\$ 166.3$ million over all readings.

When the various components of the effective price of reading DOE reports are combined, a total of $\$ 243.6$ million or $\$ 36.90$ per reading is developed.
Reading costs predominate, making up 68 percent of the total.

Components of the effective price for journal articles also include purchase and processing costs and use-related costs for identification, access, and reading. With journal articles, purchase and processing costs may be associated with personal subscriptions, library subscriptions, or article reprints. Survey results indicate that, for energy scientists, 47 percent of readings come from personal subscriptions, 46 percent from library subscriptions, and 7 percent from reprints or preprints. Costs for each of the three forms are described below, followed by discussion of the use-related costs. A summary of the costs is given in Table 3.10.

\section{Table 3.10 EFFECTIVE PRICE OF READING} JOURNAL ARTICLES*

\begin{tabular}{lcc}
\hline & \multicolumn{2}{c}{ Cost } \\
\cline { 2 - 3 } \multicolumn{1}{c}{ Cost category } & $\begin{array}{c}\text { Total, in } \\
\text { millions of } \$\end{array}$ & $\begin{array}{c}\text { Per } \\
\text { reading }\end{array}$ \\
\hline $\begin{array}{l}\text { Purchase and processing } \\
\text { Individual subscription }\end{array}$ & $(17.0)$ & $\$(5.20)$ \\
$\quad$ Library subscriptions & $(48.8)$ & $(14.80)$ \\
Reprints/preprints & $(1.0)$ & $(2.10)$ \\
$\quad$ Combined cost & 66.8 & 9.40 \\
Identification & & \\
$\quad$ Manual search & $(14.7)$ & $(22.90)$ \\
On-line search & $(4.2)$ & $(7.00)$ \\
$\quad$ RECON & $(13.0)$ & $(13.50)$ \\
$\quad$ Other & $(17.2)$ & $(8.70)$ \\
$\quad$ Combined & 31.9 & 4.50 \\
Combined total $\dagger$ & 19.9 & 2.80 \\
Access & 119.3 & 16.80 \\
Reading & 237.9 & $\$ 33.50$ \\
Total & & \\
\hline
\end{tabular}

*Source: King Research, Inc.

$\dagger$ Includes all others at $\$ 0$ for searching per reading.

\section{Personal Journal Subscription Costs}

According to survey results, 60,000 estimated DOE-funded energy researchers subscribe, on the average, to 3.1 journals each. The average price of a journal in the fields of science related to energy is $\$ 85$. Thus, the total expenditure for purchase of personal subscriptions is $\$ 15.8$ million. Processingrelated costs for individual subscriptions include ordering the subscription ( $\$ 2.10$ per subscription) and storage ( $\$ 4.40$ per subscription per year). These total $\$ 1.2$ million. The combined purchase and processing cost for personal subscriptions is thus $\$ 17.0$ 
million, or $\$ 5.20$ on the average, for each of the 3.3 million uses through personal subscriptions.

\section{Library Journal Subscription Costs}

There are a number of costs associated with library acquisition and processing of a journal, most related to the number of subscriptions. Our estimate of the number of library subscriptions is based on an estimated 16 uses per library copy of an annual volume of a journal ${ }^{5}$ or 206,000 library subscriptions for the 3.3 million uses through this channel. Costs associated with these subscriptions include subscription price, acquisitión costs, maintenance costs, and storage costs. The subscription price is taken as $\$ 85$. Acquisition costs reflect the cost of deciding to subscribe to a journal, a lengthy process estimated to cost approximately $\$ 132$ each for each of the 4,100 new orders which will be placed. Maintenance, or checkin, claiming, and shelving, costs are estimated at $\$ 43$ per subscription copy. Storage costs assume an average of 12 volumes of a title stored at $\$ 0.40$ per volume, or $\$ 4.80$ per title. These costs total $\$ 27.9$ million.

Additional costs incurred with library subscriptions are related to retrieval for use and photocopying. An average unit cost for retrieval, ${ }^{5}$ combining the costs of internal use, circulation, and interlibrary loan in appropriate proportions, is $\$ 5.50$. Photocopying costs of $\$ 2.35$ per article apply to the 36 percent of library subscription uses which involve photocopying. These two categories of costs total $\$ 20.9$ million. Total purchase and processing costs associated with library subscription uses are thus $\$ 48.8$ million, or $\$ 14.80$ per use.

\section{Preprint/Reprint Costs}

Costs associated with preprints and reprints include acquisition or ordering costs of $\$ 2.10$ per item and minimal storage costs. For the 500,000 uses through reprint copies, this amounts to $\$ 1.0$ million.

\section{Use-Related Costs}

To the costs of purchase and processing of the various journal forms must be added use-related costs for identification, access, and reading.

Table 3.4 showed the relative use of various means of identifying energy articles, including 18 percent via a computerized search, 7 percent via a printed index, and the remaining 75 percent through some other means such as browsing, a citation and so on. Identification costs for manual and on-line searches are developed similarly to those for report readings.
On-line search costs for the 602,000 article readings from RECON searches have a cost of $\$ 7.00$ per reading, or a total of $\$ 4.2$ million. For the 64,000 searches of other data bases resulting in 958,000 article readings, fixed costs are $\$ 8,250$ per library; per search costs are $\$ 30.50$; and review costs are $\$ 36.50$ for user review. Total fixed costs for an estimated 1,050 libraries are $\$ 8.7$ million or $\$ 9.00$ per article reading. Converting per search costs to per reading costs adds an additional $\$ 4.50$ for a total on-line search cost of $\$ 13.50$.

The costs of identifying articles in other ways is taken to be zero or near zero. Combining these costs appropriately, the total cost of article identification is estimated at $\$ 31.6$ million, or $\$ 4.50$ per reading.

Article access costs represent the time spent by the reader physically locating a journal issue. These costs have been estimated at $\$ 2.80$ per reading. Reading costs are based on an average time of one hour per article and an average salary of $\$ 16.80$ per hour. This totals $\$ 119.3$ million over all readings.

Combining the various components of the effective price of reading energy articles, a total of $\$ 237.9$ million or $\$ 33.50$ per reading is developed. As with reports, reading costs dominate, making up 50 percent of the total.

\subsection{CALCULATION OF SUBSTITUTES}

Some of the estimates of value of the EDB are based on the calculation of changes in searching practices (and ultimately reading practices) resulting from withdrawal of the data base. In other words, what would occur if the EDB were not available, and what would be the difference in value obtained at the same level of expenditures? The difference in value can be viewed as the value which is added by the existence of the EDB.

To make this analysis, it is necessary to identify the potential substitute services that could be used for locating energy-related literature. It is assumed that, were the EDB withdrawn, replacements would be required for EDB searching via RECON and other vendors, for $E R A$ and other TIC index searching, and (because it would no longer contain DOE titles) for NTIS Bibliographic Data File searching.

The levels of searches and reading to be substituted for are displayed in Table 3.11. In all, a total of 354,000 searches are involved. Referring to the cost data reported in Section 3.2.1, we estimate the total cost of these searches at $\$ 5.3$ million.

Examples of potential on-line substitutes are Compendex, SPIN, Biological Abstracts on Tape, 
Table 3.11 EDB-RELATED SEARCHES AND READINGS FROM SEARCHES BY DOE-FUNDED SCIENTISTS AND ENGINEERS: 1981*

\begin{tabular}{lccr}
\hline Search & $\begin{array}{c}\text { No. of } \\
\text { searches, in } \\
\text { method }\end{array}$ & \multicolumn{2}{c}{$\begin{array}{c}\text { No. of readings, } \\
\text { in thousands }\end{array}$} \\
\cline { 3 - 4 } & thousands & Articles & Reports \\
\hline EDB & 70 & 602 & 440 \\
NTIS & 40 & - & 610 \\
$E R A$ & 244 & 195 & 1,390 \\
Total & 354 & 797 & 2,440 \\
\hline
\end{tabular}

*Source: King Research, Inc.

CA Search, Science Citation Index, Envirotapes, and Medline. For manual searches, printed versions of comparable data bases would be used. Most of these available alternative data bases have very limited coverage of technical reports. Annual additions to the CA Search file, for example, include about two percent technical reports or 9000 reports across all areas of chemistry. Annual additions to the INSPEC file include one percent or about 1500 reports. Thus, we assume that substitutes used would, for the most part, result in journal article identifications.

Referring again to the cost analysis of Section 3.2.1, substitute on-line services are chosen over substitute manual services at a cost of $\$ 101.90$ per search. If the current expenditures of $\$ 5.3$ million remain fixed and are put into substitute on-line searching, 52,500 searches could be conducted. This, it is estimated, would result in 787,000 article readings in place of the 797,000 article readings and $2,440,000$ report readings lost. The total number of searches lost is 301,500 , and the number of readings lost is 10,000 article readings and $2,440,000$ report readings for a total of $2,450,000$ readings.

Similar analyses can be carried out to simulate the effect of dropping the EDB on activity within the individual program areas. Table B.5 (Appendix B) indicates the number of searches and readings lost in each program area from the same analysis. In each case, about 75 percent of the readings resulting from use of EDB products and services are lost. This ranges from 15 to 23 percent of all readings lost. For all DOE-funded scientists and engineers, withdrawal of the EDB would result in 2.45 million of a total 13.7 million readings lost, or 18 percent.

An analysis can also be made of the effect of dropping a single EDB product or service, as for example RECON. The current level of RECON searching is 70,000 , resulting in 602,000 article readings and 440,000 report readings. On-line substitutes for searching the EDB via RECON would be to search the data base on other systems, to search NTIS, or to search other data bases. Other substitutes would be the use of $E R A$ or printed substitute indexes. To conduct the analysis, we consider means of identifying reports and articles separately.

To identify technical reports, searching the NTIS data base is the most economical alternative. For articles, the use of substitute on-line data bases would be best. The cost of identifying 440,000 reports with 29,300 NTIS searches would be $\$ 590,000$, and the cost of identifying 602,000 articles with 40,000 substitute on-line searches would be $\$ 4,080,000$ for a total cost of $\$ 4.7$ million or $\$ 68.00$ per search. Now, if RECON were not available, current expenditures of $\$ 1.2$ million for RECON searching would be spent instead on 17,700 of these substitute searches. The number of readings resulting would be 266,000 . From this analysis, we find that eliminating RECON would result in a loss of 51,600 searches and 776,000 readings. The latter is 24 percent of EDB readings and 6 percent of all readings.

\subsection{VALUE OF THE EDB}

As indicated in Section 2.3, several types of value are identified for the Energy Data Base. We distinguish between apparent value, or value derived from the amount a user is willing to pay, and consequential value, or value resulting from use. In looking at secondary products and services, such as RECON and $E R A$, we look at their apparent value to searchers and their consequential value in terms of the readings which result. This reading of primary energy materials can also be seen in terms of apparent value (the price paid for it) and consequential value expressed as savings resulting from the use of the information. Further, we distinguish between these values and the concept of added value at each level. Added value is derived by looking at what would happen if a particular product or service were eliminated, modelling events and resulting value under those circumstances, and expressing what would be lost as the added value of that product.

To calculate these measures of value, data required are the volumes of searching and reading, their associated effective prices, and an estimate of the value derived from reading. All but the last have been developed earlier in this chapter.

To arrive at the value derived from reading, scientists and engineers were asked about the last journal article they read and whether or not reading 
it resulted in any savings of time, material, or equipment. Data from all scientists and engineers, reported in Scientific Journals in the United States, ${ }^{5}$ suggested that savings occurred with 24 percent of all readings and that the average savings per reading was $\$ 465$, including both time and equipment savings. Responses from energy scientists only to this question showed a comparable 25 percent reporting savings. The average article savings for energy scientists and engineers was $\$ 590$. This is taken as the consequential value of reading an energy journal article. These results could not be broken down by DOE program area, and so the same value was used in each program area.

Value associated with report reading was identified in the surveys of DOE-funded scientists and engineers described in Appendix A. In addition to asking for the dollar savings, respondents were also asked to describe how their time was saved. Verbatim responses from all researchers indicating savings in either dollars or time are listed in Appendix D. Over all respondents, 75 percent did indicate a savings and the average savings per report reading can be calculated as $\$ 1,280$. Average savings values in the five program areas considered ranged from $\$ 930$ in health and environmental research to $\$ 1,840$ in the fusion area (See Table B.6). The percent of readings resulting in savings also varied among the programs, from 57 percent in the basic energy sciences to 86 percent in defense. given in Tables B.7-B.9. These tables all indicate apparent value to searchers, apparent value to readers, and the consequential value to DOE as the funding organization.

Table 3.12 indicates the value associated with all report and article reading by DOE-funded scientists

Table 3.12 VALUE OF ENERGY

INFORMATION TO SEARCHERS, READERS, AND ORGANIZATIONS/FUNDERS: DOE-FUNDED SCIENTISTS AND ENGINEERS: 1982*

\begin{tabular}{ll}
\hline Searchers & $\$ 47$ million \\
Readers & $\$ 500$ million \\
Organizations/funders (DOE) & $\$ 13$ billion \\
\hline
\end{tabular}

*Source: King Research, Inc.

and engineers, that is, 6.6 million report readings and 7.1 million article readings by 60,000 researchers. The $\$ 13$ billion savings represented by the value to DOE can be seen as a return on an investment of $\$ 500$ million in reading costs, for a net value of $\$ 12.5$ billion and a benefit-to-cost ratio of 26 to 1 .

Considering only EDB products and services, that is, TIC standard distribution of DOE research reports and on-line and manual searching of the EDB, Table 3.13 reflects the value of about 3.2 mil-

\section{Table 3.13 VALUE OF THE ENERGY DATA BASE TO SEARCHERS, READERS, AND ORGANIZATIONS/FUNDERS: DOE-FUNDED SCIENTISTS AND ENGINEERS: 1982*}

\begin{tabular}{lll}
\hline & $\begin{array}{c}\text { Found by } \\
\text { substituting } \\
\text { for the EDB }\end{array}$ & $\begin{array}{c}\text { Directly } \\
\text { attributable to } \\
\text { the EDB }\end{array}$ \\
\hline $\begin{array}{l}\text { Searchers } \\
\begin{array}{l}\text { Readers } \\
\text { Organizations/funders } \\
(\text { DOE })\end{array}\end{array}$ & $\begin{array}{l}\$ 15 \text { million } \\
\$ 90 \text { million }\end{array}$ & $\begin{array}{c}\$ 20 \text { million } \\
\$ 240 \text { million }\end{array}$ \\
\hline
\end{tabular}

*Source: King Research, Inc.

Value results are expressed in Tables 3.12-3.14, addressing respectively the value of energy information, the value of the Energy Data Base, and the value of RECON. The first includes all use of energy information by DOE-funded scientists and engineers. For the latter two, both total value and added value are given. Comparable data on Tables 3.12-3.14 for the five program areas addressed are lion readings from EDB searches and 3.3 million readings from standard distribution. The value to DOE is $\$ 3.6$ billion for readings from EDB searches and $\$ 4.4$ billion for readings from standard distribution for a total of $\$ 8.0$ billion. This can again be seen as a return on an investment of $\$ 240$ million, for a net value of $\$ 7.8$ billion and a benefitto-cost ratio of 33 to 1 . 
As described in the previous section, substituting the use of other available secondary products for EDB use would, if search budgets remained constant, result in a loss of 301,500 searches and 2.45 million readings. The value equivalent, $\$ 3.0$ billion, is taken as an estimate of the value added by the EDB. This figure can be roughly translated into productivity. If it is assumed that, with the EDB, research and development costs $\$ 5.8$ billion for a given level of output, without the EDB the same output would require an investment of $\$ 8.8$ billion. This is an increase in productivity of about 52 percent. This says that to accomplish the same $R \& D$ output without TIC information services, the R \& D budget would have had to be $\$ 3.0$ billion higher. Productivity increases over the five major DOE program areas can be similarly calculated and range from 24 percent for health and environmental research to 94 percent for nuclear research.

Table 3.14 gives the value associated with RECON. Here the $\$ 900$ million value to DOE is a

Table 3.14 VALUE OF RECON TO SEARCHERS, READERS, AND ORGANIZATIONS/FUNDERS: DOE-FUNDED SCIENTISTS AND ENGINEERS: 1982* (Millions of Dollars)

\begin{tabular}{lcc}
\hline & $\begin{array}{c}\text { Found by } \\
\text { substituting } \\
\text { for RECON }\end{array}$ & $\begin{array}{c}\text { Directly } \\
\text { attributable to } \\
\text { RECON }\end{array}$ \\
\hline $\begin{array}{l}\text { Searchers } \\
\begin{array}{l}\text { Readers } \\
\text { Organizations/funders } \\
\text { (DOE) }\end{array}\end{array}$ & 5.4 & 7.3 \\
\hline
\end{tabular}

*Source: King Research, Inc. return on $\$ 36$ million invested, a benefit-to-cost ratio of 25 to 1 . The reading value can similarly be seen as a return on an investment of $\$ 7.3$ million in searching, here a return of 5 to 1 . This return is of interest to those funding RECON searchers.

\subsection{APPLICATION OF THE VALUE CONCEPT}

When the concept of value obtained from energy information products and services is utilized, a number of contemporary information issues can be analyzed. While these analyses must be complemented with consideration of legal, administrative, political, and social impacts as well, addressing the value questions provides an important perspective from which to make decisions. It is hoped that providing this perspective and carrying out the relevant analyses will contribute to a better understanding of the issues and present some guiding principles for future directions.

One related set of special issues addressed in this study was Federal and non-Federal relationships in information activities. The results of that part of the analysis are presented in a related King Research report for the DOE Technical Information Center, Federal and Non-Federal Relationships in Providing Energy Information.

Another potential application of the value concept is in considerations of productivity improvement. In this report, the impact of information products and services on productivity has been roughly estimated. In additional work, this area will be pursued further to determine if the application of value results to research program productivity is consistent with existing models of U. S. productivity. 


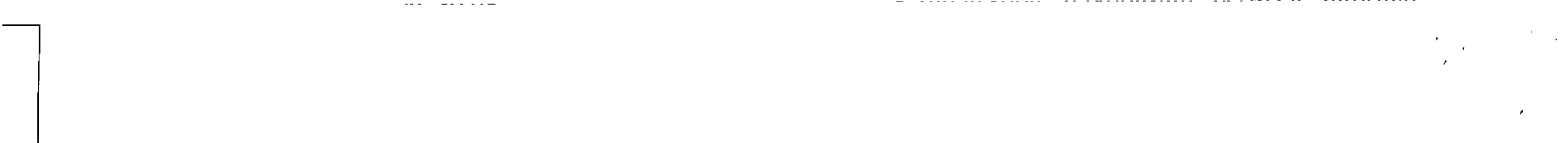




\section{APPENDIX A}

\section{DATA COLLECTION METHODS}




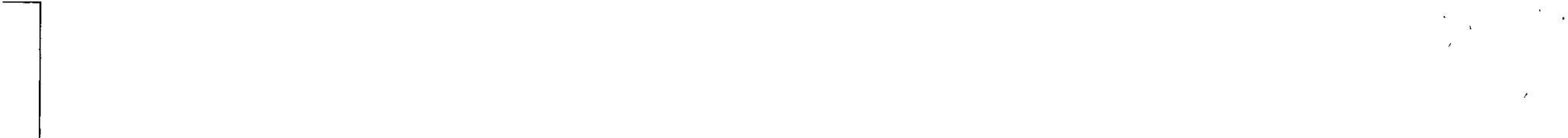




\section{APPENDIX A}

\section{DATA COLLECTION METHODS}

Data used in this study came from several different sources, including TIC records, previously conducted studies, and two new data collection or analysis activities. Sources of data are indicated in the text of this report; this appendix documents the two new activities performed, that is, the analysis of previously obtained questionnaire responses dealing with the use of journals and the conduct of small surveys of energy researchers to explore other information activities.

The former effort utilized the data base of survey responses obtained in a King Research study of scientific and technical communication indicators. Results of this survey are presented in Scientific Journals in the United States: Their Production, Use, and Economics. ${ }^{5}$ The survey was conducted with a random sample of scientists from society membership lists and lists of engineers and computer scientists supplemented by a random sample of journal article authors. Those sampled from these three sources were sent questionnaires, and there was a telephone follow-up. This process yielded a total useable sample of 2,350. Information obtained in the survey was used to weigh results to adjust for multiple society membership and disproportionate sampling from various strata. Data obtained and analyzed covered extent of authorship, journal readership, article use, subscription behavior, and use of bibliographic and numeric data bases.

Survey responses form a comprehensive data base on use of information across the fields of science. For the TIC study, data were needed specifically on scientists in the energy field, and so the original 2,350 responses were reviewed to cull out only those individuals associated with energy. Several questions were reviewed to make this determination: for authors, the journal and article title of articles written by them; the title of the last journal read; and the field of science in which the individual worked. In most cases it was clear from these responses whether the individual worked in the energy field. When questions arose, journal titles were checked against the frequency list for EDB coverage, and those journals with extensive coverage in the EDB were considered energy journals.

The resulting data base subset contained 148 responses which were then tabulated and analyzed. The results of this process are discussed primarily in Section 3.1 of this report. To indicate the availability of additional data, the survey questionnaire is included in this Appendix as Exhibit A-1.

Results of that survey did not address report use, information also needed for the determination of the value of the EDB. While some report use data was available from other sources, confirming evidence was sought. Additional data were also desired on use of TIC indexes and data bases specifically. For these purposes, a small group of surveys was performed of institutions and individuals obtaining TIC products and services.

For reports, surveys were performed of institutions receiving copies of technical reports from TIC via the following channels: standard distribution, paper copy form; standard distribution, microform; TIC on-demand distribution; and NTIS on-demand distribution. The sample for each was developed by random selection from lists of institutions using each channel. Interviewing was done by telephone; the basic approach was to obtain some background information from the organization's library and ask them to try to identify one or two individual users. These individuals were in turn contacted and asked about their information use.

Originally we hoped to be able to trace specific DOE report titles and thus obtain estimates of demand by title. For this purpose, a sample of titles was drawn randomly from Volume 6, Number 14 issue of $E R A$. In most institutions, however, tracing of individual titles could not be accomplished (at least not within our time constraints). Procedures were modified accordingly.

The report user questionnaires addressed a specific report read (the identified title or the last title read) and covered report form, time spent, 
method of identification, method of access, purposes of use, and time and other savings as a result of reading the report. These varied somewhat according to the distribution channel being considered, but generally included the questions included in Exhibit A-2 of this appendix, "Report User Questions." All users were also asked about their extent of use generally of reports, articles, and books.

To obtain data on use of TIC indexes, institutions obtaining $E R A$ through TIC and through GPO were surveyed, again using random sampling from the appropriate lists. Libraries were asked about the level of manual and on-line bibliographic searching at their institution and to identify a known user of a TIC index. Individuals thus reached were asked about their most recent use of a TIC index, with questions covering time spent; purpose of search; and number of items identified, accessed, read, and found useful. (See Exhibit A-3, "Index User Questions.")

For data on RECON searching, the list of RECON users was randomly sampled and contacted. At the institution levels, questions asked concerned volume of on-line and manual searching and time spent on each. Names of individual users were also obtained. Search users were then asked about their most recent search, including purpose of search, and number of citations received, if relevant, accessed, read, and found useful. (See Exhibit A-4, "RECON User Questions.")

A follow-on effort concerned with obtaining data specific to five individual program areas within the energy field was also conducted. In this case, organizations doing work in the program areas were identified and contacted and asked to provide names of individuals. Individuals contacted were asked some background questions about their use of energy information. (See Exhibit A-5, "Program Area User Questions.") Depending on his response, an individual was then asked a series of questions about technical reports (Exhibit A-6) and questions about his use of either printed indexes (Exhibit A-7) or on-line data bases (Exhibit A-8). The goal was to obtain nine index and nine on-line data base responses per program area, or forty-five of each. Actual results were 48 responses to the index questions and 41 to the on-line data base questions. Over the five program areas, a total of 130 screening questionnaires were completed, and 115 respondents provided report data. Data obtained in these surveys were used for analyses done by program area and also used to supplement data obtained from earlier surveys. Total responses from all report survey instruments were 188 , with report data obtained from 152 of the respondents, printed index data from 64 of the respondents, and on-line search data from 46 of the respondents. 


\section{EXHIBITS}


This project is being supported by the National-Science Foundation Division of Science Information under Contract NSF DSI75-06942

\section{EXHIBIT A-1}

\section{JOURNAL USER QUESTIONNAIRE}

NATIONAL SCIENCE FOUNDATION

SURVEY OF THE USE OF

SCIENTIFIC AND TECHNICAL INFORMATION

The purpose of this survey is to determine how different sources of scientific and technical information are used by individuals involved in some way with research and development.* This includes the actual performance of research and development, as well as management, supervision, teaching, and training related to its performance.

Because your answers are ex tremely important to the accuracy of our study, please return the questionnaire even if you are unable to answer all the questions.

Your responses are voluntary and confidential.

Data will be reported only in aggregated form.

We've tried to keep the questionnaire as short and simple as possible. Just circle the appropriate code number $(1,2,3$, etc. $)$, or write in your answer in the space provided.

If you are not currently involved with research and development, including actual performance of research and development as well as related management, supervision, teaching, and training, please put a check mark here $\square$ and return this questionnaire without filling it out.

*SCIENTIFIC AND TECHNICAL INFORMATION is knowledge or data resulting from the conduct of research and development or required for managing, organizing, administering, or performing research and development. It encompasses any information, existing in recorded or other communicable form, which presents the status, progress, or results of research and development in any area of science or technology and which has some potential use in furthering the advancement of current and future research and development. Subject areas include: Physical Sciences, Mathematics and Computer Sciences, Environmental Sciences, Engineering, Life Sciences, Psychology, Social Sciences and other sciences.

RESEARCH is systematic, intensive study directed toward fuller scientific knowledge or understanding of the subject studied. In $B A S I C$ RESEARCH the investigator is concerned primarily with gaining a fuller knowledge or understanding of the subject under study. In APPLIED RESEARCH the investigator is primarily interested in a practical use of the knowledge or understanding for the purpose of meeting a recognized need. DEVELOPMENT is systematic use of the knowledge and understanding gained from research, directed toward the production of useful materials, devices, systems, or methods, including design and development of prototypes and processes. It excludes quality control, routine product testing, and production. 


\section{AUTHORSHIP}

1A. During the past 12 months, how many of the articles that you authored or co-authored have been accepted for publication in referred professional, scientific or technical journals (excluding bulletins, newsletters, trade journals and other publications that do not report or review research)?(Insert number in box provided, zero "O" if none.)

Number accepted for publication solely in the U.S. . . . . . .

Number accepted for publication solely outside the U.S.. . . . .

Number accepted for publication both within

the U.S. and outside. . . . . . . . . . . . . .

Number rejected and resubmitted to another joumal . . . . . .

Number rejected and not resubmitted to another journal .... 
JOURNAL USAGE

2A. How long has it heen since you last read an article from a refereed professional, scientific or technical journal? By "reading" we mean going beyond the contents, title and abstract, to the body of the article.

If it has been more than a month since you last read a journal article, please skip to Q.6A.

2B. How many of these journal articles have you read in the past month? (Record number in box.)

2C. What is your best estimate of the total time in hours and minutes that you spent reading these journals?

Hours

Minutes

2D. What is the title of the journal which published the article you read last?

Journal title

Questions 3A through 5C refer to the journal article that you read most recently.

3A. In what year was this article published?

3B. In what country was the author located at the time that the article was written?

Country

3C. How did you initially find out about this last article you read?

By accident while browsing in an issue. . . . . . . . . . .

From another person (i.e., a colleague) $\ldots \ldots \ldots \ldots \ldots$

Cited in another article $\ldots \ldots \ldots \ldots \ldots \ldots \ldots$

Cited in a printed index $\ldots \ldots \ldots \ldots \ldots \ldots$

In the output of a computerized literature search $\ldots \ldots \ldots \ldots$

Other (describe) _ . . .6

3D From which source did you obtain physical access to this last article? (Circle code number of the most applicable response.)

My own subscription copy of the journal . . . . . . . . . . I

A library copy of the journal . . . . . . . . . . . . . . 2

The author of the article (who is not a co-worker in my place of employment $\ldots \ldots \ldots \ldots \ldots \ldots$

The author of the article (who is a co-worker in my place of employment). . . . . . . . . . . . . .

A co-worker in my place of employment (who was not the author). . .5

Other (describe)

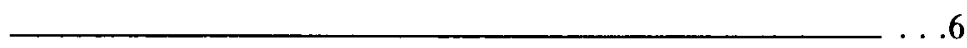

Don't remember $\ldots \ldots \ldots \ldots \ldots \ldots \ldots \ldots \ldots \ldots \ldots \ldots \ldots \ldots \ldots \ldots$

3E. In what form was this article when you read it?

Actual issue of the journal, either by itself

or in a bound volume $\ldots \ldots \ldots \ldots \ldots \ldots \ldots \ldots$

Actual reprint of the article (do not include

a photocopy such as a Xerox copy) . . . . . . . . . . .

A preprint, obtained prior to the article's being published . . . . . . 3

Microfilm or microfiche edition of the journal

in which it appeared. . . . . . . . . . . . . . .

A photocopy (e.g., Xerox copy) of the article . . . . . . . . . . . .5

A hardcopy of the article made from a microform reader-printer . . .6

Other source (e.g., hard-bound anthology) . . . . . . . . . . 
3F. How thoroughly did you read this article?

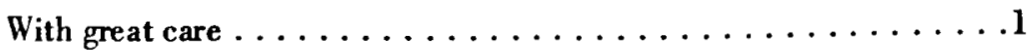

With attention to the main points. . . . . . . . . . .

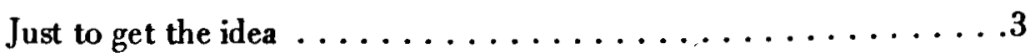

3G. Have you or a secretary or assistant made a photocopy (e.g., Xerox copy) of this article?

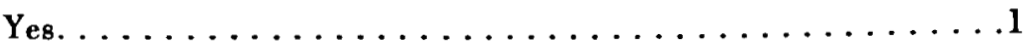

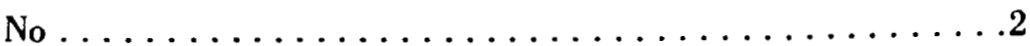

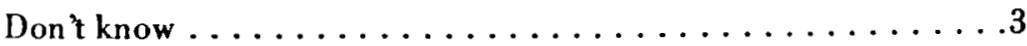

4A. Did you know about the research reported or reviewed in this article prior to reading it? (Circle only one response.)

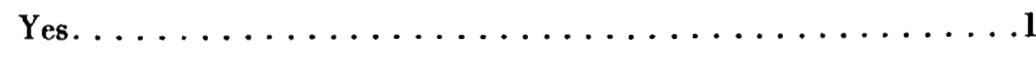

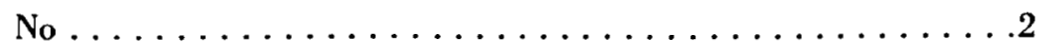

No research was reported or reviewed in this article $\ldots \ldots \ldots \ldots$

Don't know .........................

4B. In which of the following ways have you used, or do you plan to use, the last article you read? (Circle 1,2 , or 3 for each response.)

\begin{tabular}{|c|c|c|}
\hline$\underline{\text { Yes }}$ & $\underline{\text { No }}$ & $\begin{array}{l}\text { Don't } \\
\text { Know } \\
\end{array}$ \\
\hline To apply its findings to a current project . . . . . . l & 2 & 3 \\
\hline To apply its methodology to a current project . . . . I & 2 & 3 \\
\hline In preparation of a research proposal. . . . . . . . l & 2 & 3 \\
\hline In preparation of an article, book, review, or report. .l & 2 & 3 \\
\hline $\begin{array}{l}\text { As a citation in a journal article, book, review } \\
\text { or report } \ldots \ldots \ldots \ldots \ldots \ldots \ldots \ldots \ldots \ldots \ldots\end{array}$ & 2 & 3 \\
\hline $\begin{array}{l}\text { For professional development, current } \\
\text { awareness, or general interest. . . . . . . . }\end{array}$ & 2 & 3 \\
\hline In preparation of a lecture or presentation $\ldots \ldots \ldots$. & 2 & 3 \\
\hline $\begin{array}{l}\text { For the planning, budgeting and } \\
\text { management of research } \ldots \ldots \ldots \ldots \ldots \text {. }\end{array}$ & 2 & 3 \\
\hline Other (describe) & & \\
\hline
\end{tabular}

5A. Has reading this article saved you and/or your co-workers any time on any current task or project?

(GO TO Q.5B)

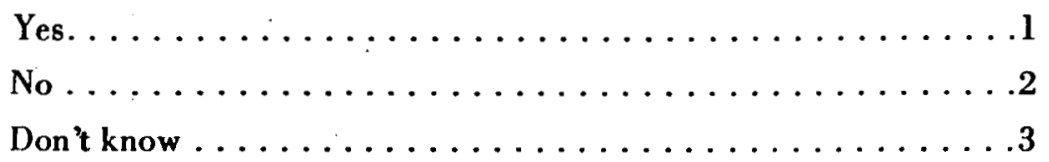

5B. Considering only direct salaries, what is the approximate dollar value of the time you and/or your coworkers saved? (Insert zero " 0 " if none.)

5C. What, if any, were the dollar savings for other things such as equipment and supply costs? (Insertzero " 0 " if none.)

\section{SUBSCRIPTION}

6A. Do you now have a personal subscription to any refereed professional, scientific, or technical journals? By "personal subscription" we mean one which is personally addressed to you at your home, office, or lab. Exclude from consideration bulletins, newsletters, trade journals and other publications that do not report or review research.

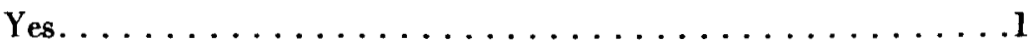

(GO TO Q.7A)

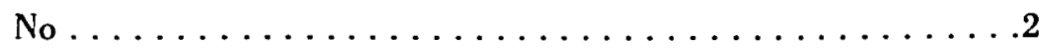


6B. What is the TOTAL number of personal journal subscriptions you receive? (Insert number in box.)

6C. Of these subscriptions (total from 6B), how many are paid for entirely from your own personal funds?

6D. How many are paid for partially or entirely by someone else?

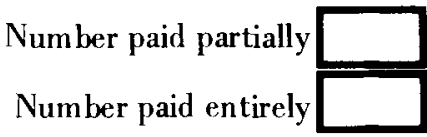

\section{(If zero to $6 D$, skip to $6 F$. Otherwise, please answer 6E.)}

6E. Of those paid for partially or entirely by someone else (totals from 6D), how many are paid for by the Federal government (e.g., charged directly to a government contract or grant)?

Number paid partially

Number paid entirely

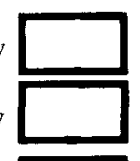

6F How many of the subscriptions you receive (total from 6B) are published by Societies or Associations?

$$
\text { (If zero to } 6 F \text {, skip to } 7 A \text {. Otherwise, please answer 6G.) }
$$

66. Of these, how many are included with payment of your membership fee?

NUMERIC DATA BASE USAGE

7A. Have you searched or used the output of any numeric data bases during the last two weeks? By "numeric data bases" we mean computerized or computer-readable files, listings or printouts which are primarily numeric in nature and which are produced by your own research or by others. (Include any data you use that you recognize to be the output of a numeric data base.)

$(G O T O Q .7 B)$

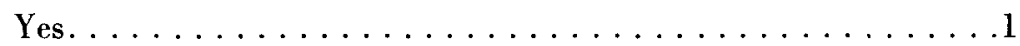

(GO TO Q.8A)

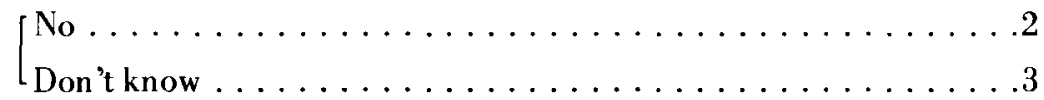

7B. In the past two weeks, have you used any of the following types of numeric data bases (excluding data bases produced as a result of your own research)? (Circle 1,2 , or 3 for each type of data base.)

Social characteristics data bases (e.g., Census Yes No Kon't tapes, Bureau of Labor Statistics data, health

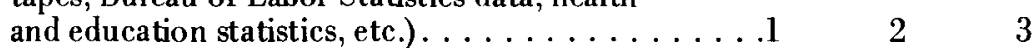

Engineering and physical value data bases (e.g., results of physical testing, computerized tables of standard physical or numeric values, etc.). . ...1 23

Environmental and geographic data bases (e.g., price indexes, trade and industry statistics,

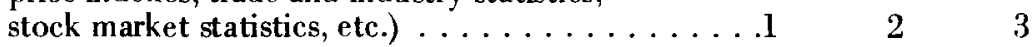

Other (describe)

7C. What is your best estimate, in hours and minutes, of the total time you have spent using numeric data bases during the past two weeks?

$$
\begin{array}{r}
\text { Hours } \\
\text { Minutes }
\end{array}
$$


8A. Have you searched or used the output of any computerized bibliographic data bases during the last two weeks to aid in a literature search? (Include any data you use that you recognize to be the output of a bibliographic data base.)

$(G O T O Q .8 B)$

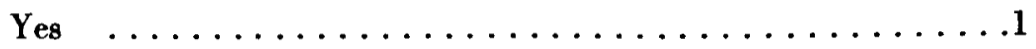

(GOTOQ.9A)

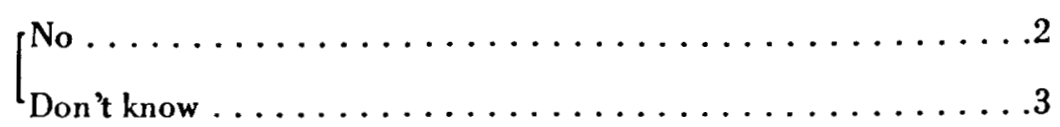

8B. Did you personally conduct the computerized literature search, did you examine the output, or did you do both?

Performed search. .......................

Examined output $\ldots \ldots \ldots \ldots \ldots \ldots \ldots \ldots \ldots \ldots \ldots \ldots \ldots \ldots \ldots \ldots$

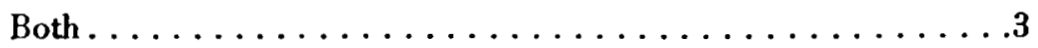

Don't know $\ldots \ldots \ldots \ldots \ldots \ldots \ldots \ldots \ldots \ldots \ldots \ldots \ldots \ldots \ldots \ldots \ldots \ldots$

8C. About how much time in hours and minutes did you spend searching and/or using the output of the bibliographic data bases?

Hours

Minutes

\section{CLASSIFICATION}

These last questions help us to analyze responses by type of respondent. Your answers will be kept confidential and used only in combination with those of other scientists or engineers.

9A. What is the highest degree you have earned? (Circle only one.)

Bachelor's (B.A., B.S., or equivalent). . . . . . . . . . . . 1

Master's (M.A., M.S., or equivalent) . . . . . . . . . . . .

Medical (M.D. or equivalent) . . . . . . . . . . . . 3

Doctorate $(\mathrm{Ph} . \mathrm{D} ., \mathrm{Sc}$.. , or equivalent) . . . . . . . . . . . .

Both MD. and PhD. (or equivalent) $\ldots \ldots \ldots \ldots$

Other (describe) _ _ . . . 6

9B. In what year did you receive your last degree? . . . . . . . . . . . . . . . . . . 19

9C. What is your age?

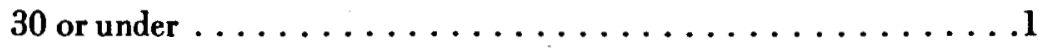

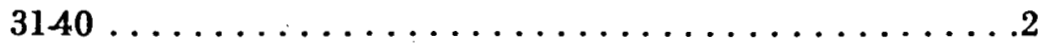

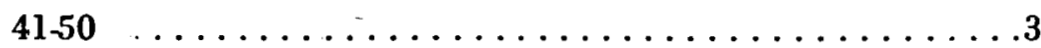

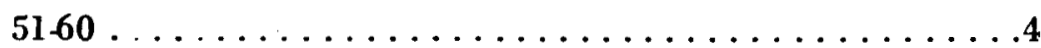

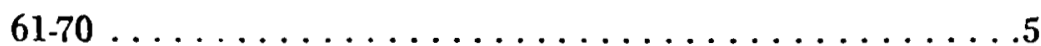

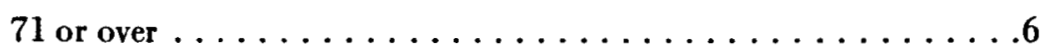

9D. What is your sex?

Male ..........................

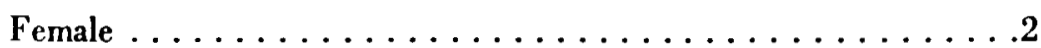


9E. What is the field of science or engineering which best characterizes your area of work? (If more than one applies, please indicate the one which best characterizes the application of your work.)

Physical Science (Astronomy, Chemistry, Physics, etc.) . . . . . .

Mathematics, Statistics, Computer Science . . . . . . . . . 2

Environmental Science (e.g., Conservation, Geography, Geology,

Geophysics, Oceanography, or Atmospheric Science ..........3

Engineering . .......................

Biology, Agriculture, Medicine, Pharmacy, Plant Science,

Animal Sciences, and other Life Sciences. . . . . . . . . . . 5

Psychology, Psychiatry . . . . . . . . . . . . . . 6

Sociology, Economics, Anthropology, History,

Urban Planning, and other Social Sciences . . . . . . . . . . .

Other (describe)

9F. Are you primarily employed by:

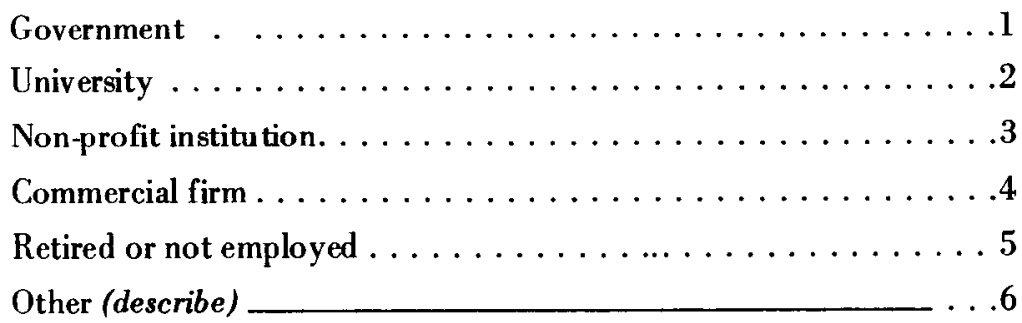

9G. Please circle the code number of the category which best describes the work role in which you spend the largest proportion of your time.

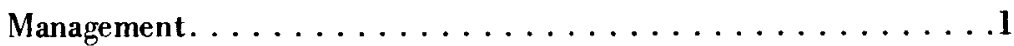

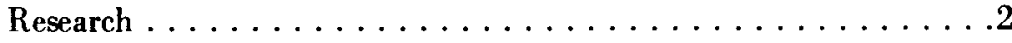

Teaching $\ldots \ldots \ldots \ldots \ldots \ldots \ldots \ldots \ldots \ldots \ldots \ldots \ldots \ldots \ldots \ldots$

Medical practice $\ldots \ldots \ldots \ldots \ldots \ldots \ldots \ldots$

Retired or not employed. . . . . . . . . . . . . . . .

Other (describe)

9H. Is any of your current work funded by the Federal government?

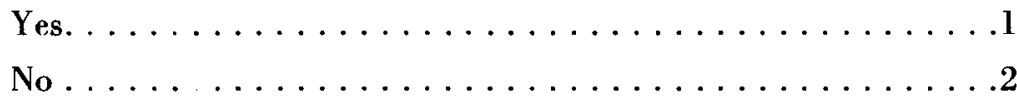

9I. Who supplies the largest proportion of funds for your current projects?

Government ........................

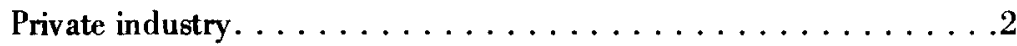

Educational institution . . . . . . . . . . . . .

Nonprofit institution. . . . . . . . . . . . . . .

Other (describe)

9J. To how many professional Societies or Associations do you belong? (Insert number in box.)

Thank you for your help. If you have any comments, please use the space on the back of the questionnaire.

Please do not sign your name. 


\section{EXHIBIT A-2 \\ REPORT USER QUESTIONS}

1. We understand that you may have used a DOE report entitled

Do you remember the report?

$$
\begin{aligned}
& \text { Yes } \square \text { (go to Q.4) } \\
& \text { No } \square \text { (go to Q.2) }
\end{aligned}
$$

2. What is the title of the technical report you last read?

3. Was it in paper copy or microfiche form?

Paper copy

Microfiche

4. What is your best estimate of the time in hours and minutes that you spent reading this report?

Hours Minutes

5. How did you initially find out about the technical report?

While browsing

From another person (i.e., a colleague)

Cited in another report

Cited in a journal article

Cited in a printed index

Which index?

Energygram or newsletter

In the output of a computerized literature search

Which data base was searched? 
And which service was used?

Other (describe)

6. How thoroughly did you read this report?

With great care

With attention to the main points

Just to get the idea 3

7. To how many others did you recommend this report?

8. From which source did you obtain physical access to this technical report?

NTIS, GPO, etc.

A library copy of the report $\quad 2$

The author of the report (who is not a co-worker in my place of employment) 3

The author of the report (who is a co-worker in my place of employment) $\quad 4$

A colleague or acquaintance (who was not the author) 5

Other (describe)__ $\quad 6$

$\begin{array}{ll}\text { Don't remember } & 7\end{array}$

9. How much did you or your organization pay for this report?

10. What would you have been willing to pay for it from your own personal funds?

From your organization?

11. In which of the following ways have you used, or do you plan to use, this report?

Yes No

To apply its findings to a current project

12

$\begin{array}{lll}\text { To apply its methodology to a current project } & 1 & 2\end{array}$

$\begin{array}{lll}\text { In preparation of a research proposal } & 1 & 2\end{array}$

In preparation of an article, book, review, or report $\quad 1 \quad 2$

As a citation in a journal article, book, review or report $\quad 1 \quad 2$

For professional development, current awareness, or general interest $\quad 1 \quad 1 \quad 2$

$\begin{array}{lll}\text { In preparation of a lecture or presentation } & 1 & 2\end{array}$

$\begin{array}{lll}\text { For the planning, budgeting and management of research } & 1 & 2\end{array}$ 
Other (describe)

12. Has reading this report saved you and/or your co-workers any time on any current task or project?

$\begin{array}{ll}\text { Yes } & 1 \\ \text { No } & 2 \\ \text { Don't Know } & 3\end{array}$

13. Considering only direct salaries, what is the approximate dollar value of the time you and/or your co-workers saved? (Insert zero " 0 " if none.)

14. What, if any, were the dollar savings for other things such as equipment and supply costs? (Insert zero " 0 " if none.)

15. During the past month, how many of the following have you read? What is your best estimate of the total time in hours and minutes that you spent reading these products?

$\underline{\text { Number }}$ Hours Minutes

- Technical reports

- Technical articles in journals

- Chapters in technical books

- Other technical reading (describe) 


\section{EXHIBIT A-3}

\section{INDEX USER QUESTIONS}

1. You have been identified as a recent user of a DOE printed index. Which index did you use most recently?

2. Why did you perform this search?

3. How much time did you spend searching?

4. How many relevant items did you identify?

5. How many of these items were:

Reports__

Journal articles

Other materials.

6. To how many of these items did you physically obtain access (or intend to obtain access)?

7. How many items did you read (scan beyond the title page)?

8. How many items did you find useful?

9. How often do you search DOE indexes? 


\section{EXHIBIT A-4}

\section{RECON USER QUESTIONS}

1. You have been identified as a recent user of a RECON data base. Which data base did you use most recently?

2. For what purpose did you have the search performed?

To apply its findings to a current project

To apply its methodology to a current project

In preparation of a research proposal

In preparation of an article, book, review, or report

As a citation in a journal article, book, review or report

For professional development, current awareness, or general interest

In preparation of a lecture or presentation

For the planning, budgeting and management of research

Other (describe)

3. How many citations did you receive as output from the search?

4. How many citations were relevant?

5. How many of the relevant citations were to

Reports

Journal articles

Other materials?

6. To how many of these items did you actually obtain access?

7. How did you get access?

8. How many items did you read?

9. How many items did you find useful?

10. How many items did you recommend or pass on to others?

11. How often do you request searches? 


\section{EXHIBIT A-5}

\section{PROGRAM AREA USER QUESTIONS}

1. We are interested in finding out about your use of energy-related publications, particularly those distributed by the DOE's Technical Information Center. I am going to read you a list of five products and services provided by TIC. For each one, I would like to know

- whether you have used the product or service in the last year

- if yes, the number of times you use the product or service in an average month

- the number of hours you spend using the product or service in an average month

\begin{tabular}{|c|c|c|c|c|}
\hline \multirow[b]{2}{*}{ Product or service } & \multicolumn{2}{|c|}{$\begin{array}{l}\text { Used in } \\
\text { the last } \\
\text { year? }\end{array}$} & \multirow{2}{*}{$\begin{array}{c}\text { Average } \\
\text { monthly } \\
\text { uses }\end{array}$} & \multirow[b]{2}{*}{ Time spent using } \\
\hline & Yes & No & & \\
\hline a. Technical reports in paper copy & $\square$ & $\square$ & & \\
\hline b. Technical reports on microfiche & $\square$ & $\square$ & & \\
\hline c. Energy Research Abstracts & $\square$ & $\square$ & & \\
\hline d. Other printed TIC indexes & $\square$ & $\square$ & & \\
\hline e. Energy Data Base through RECON searches & $\square$ & $\square$ & & \\
\hline
\end{tabular}

2. We are also interested in your use of other sources of energy information. Please indicate your average monthly use and the time spent on the following:

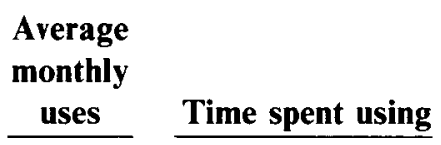

a. Non-DOE technical reports

b. Journal articles

c. Other materials

3. What proportion of your time is funded by the Department of Energy? By which program or programs of DOE?

\section{Defense \\ Nuclear \\ Energy Research}

Fusion

Basic Energy Sciences

Health and Human Effects

Other 


\section{EXHIBIT A-6}

\section{PROGRAM AREA REPORT USER QUESTIONS}

\section{Report Questions}

1. What is the title of the DOE technical report you last read? By "reading" we mean going beyond the title and abstract to the body of the report. By "DOE report" we mean a report prepared by DOE or under a DOE contract. Circle appropriate key number.

2. How did you initially find out about this technical report?

By accident while browsing

From another person (i.e., a colleague)

Cited in another report

Cited in a journal article

Cited in a printed index

Which index?

Energygram or newsletter

Library announcement bulletin

In the output of a computerized literature search

Which data base was searched?

And which service was used?

Other (describe)

3. From which source did you obtain physical access to this technical report?

My own copy of the report

A library copy of the report

The author of the report (who is not a co-worker in my place of employment)

The author of the report (who is a co-worker in my place of employment)

A colleague or acquaintance (who was not the author)

Other (describe)

Don't remember

4. How thoroughly did you read this report?

With great care

With attention to the main points

Just to get the idea

5. To how many others did you recommend this report?

6. In which of the following ways have you used, or do you plan to use, the last report you read?

To apply its findings to a current project

To apply its methodology to a current project

$\begin{array}{ccc}\text { Yes } & \text { No } & \text { Don't Know } \\ 1 & 2 & 3 \\ 1 & 2 & 3\end{array}$


In preparation of a research proposal

In preparation of an article, book, review, or report

As a citation in a journal article, book, review or report

\begin{tabular}{|c|c|c|}
\hline Yes & No & Don't Know \\
\hline 1 & 2 & 3 \\
\hline 1 & 2 & 3 \\
\hline 1 & 2 & 3 \\
\hline
\end{tabular}

For professional development, current awareness,

or general interest

In preparation of a lecture or presentation

For the planning, budgeting and management of research

No use

Other (describe)

$\begin{array}{lll}1 & 2 & 3 \\ 1 & 2 & 3 \\ 1 & 2 & 3 \\ 1 & 2 & 3 \\ 1 & 2 & 3\end{array}$

7. Has reading this report saved you and/or your co-workers any time on any current task or project?

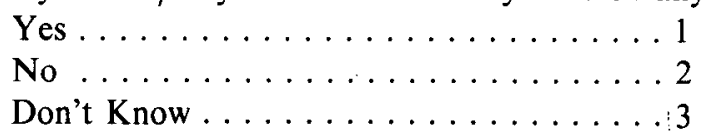

8. Considering only direct salaries, what is the approximate dollar value of the time you and/or your co-workers saved? (Insert zero " 0 " if none.)

9. What, if any, were the dollar savings for other things such as equipment and supply costs?

(Insert zero " 0 " if none.)

10. Could you describe how it saved you time?

(Probe: What would you have had to do if you had not read that particular information?) 


\section{EXHIBIT A-7}

\section{PROGRAM AREA INDEX USER QUESTIONS}

\section{Index Questions}

1. What was the purpose of the last ERA or other DOE printed index search you performed or had performed for you?

2. Did you personally perform the search, or was it performed for you?

Performed search personally

Search was performed by someone else $\square \quad$ Who?

3. How much time did you spend on the search?

4. a. How many relevant items did you identify?

b. How many of these items were

\section{Reports}

Journal articles

Other materials

5. To how many of these items did you physically obtain access (or intend to obtain access)?

6. a. How many items did you read (scan beyond the title page)?

b. How many of these items read were

Reports

Journal articles

Other materials

7. How many items did you find useful? 
EXHIBIT A-8

\section{PROGRAM AREA ON-LINE SEARCH QUESTIONS}

\section{Search Questions}

1. What was the purpose of the last EDB search you performed or had performed for you?

2. Did you personally perform the search, or was it performed for you?

Performed search personally

Search was performed by someone else $\square$ Who?

3. How much time did you spend

Preparing for search

Actually conducting the search

Reviewing search output

4. How many citations did you receive as output from the search?

5. a. How many citations were relevant?

b. How many of the relevant citations were to

Reports

Journal articles

Other materials

6. To how many of these items did you actually obtain access?

7. a. How many items did you read?

b. How many of these items read were

Reports

Journal articles

Other materials

8. How many items did you find useful? 


\section{APPENDIX B}

\section{PROGRAM AREA RESULTS}

$55 / 56$ 

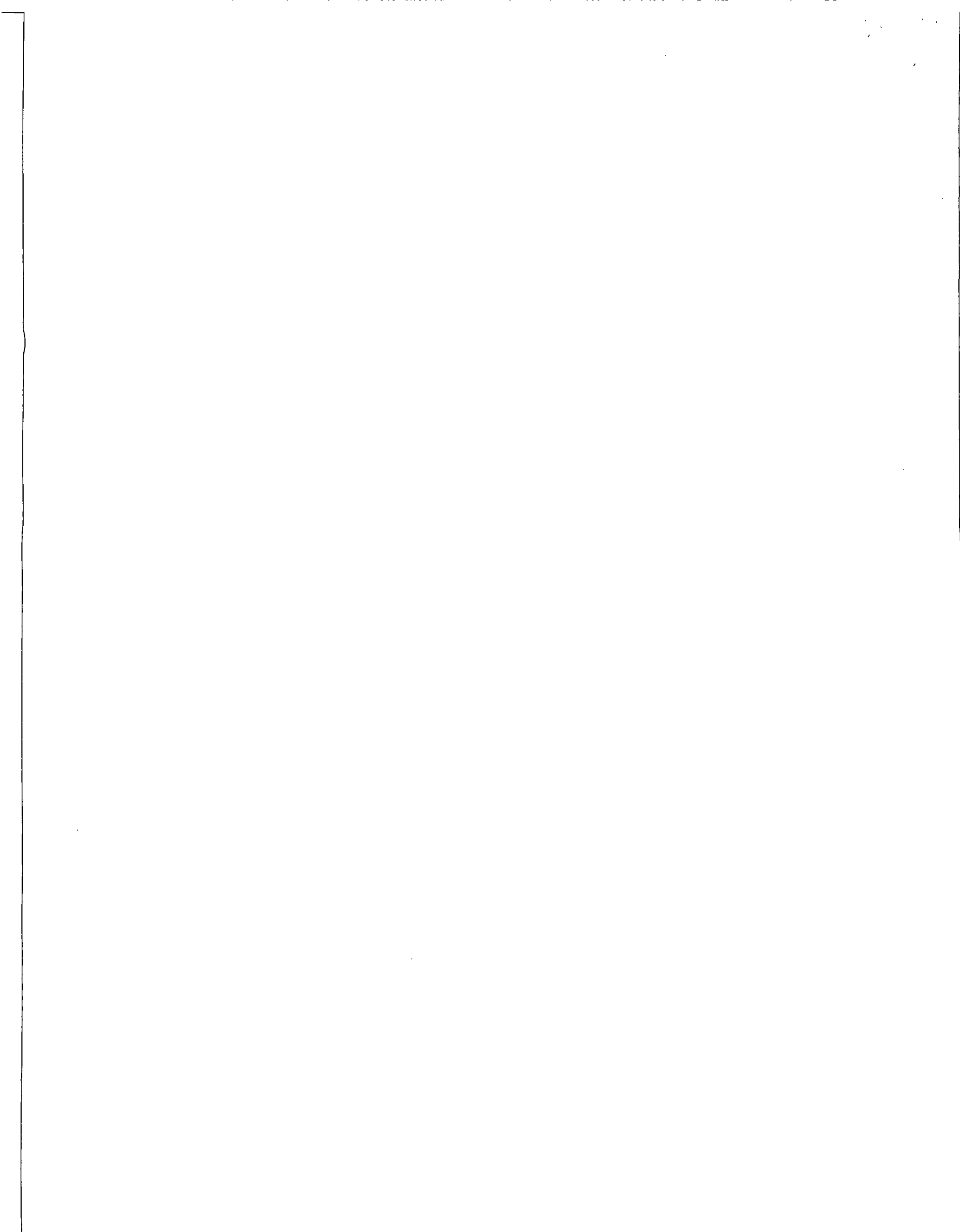
Table B.1 RESEARCH FUNDING AND NUMBER OF FUNDED SCIENTISTS AND ENGINEERS IN FIVE DOE PROGRAM AREAS: 1981*

\begin{tabular}{lccccccc}
\hline & \multicolumn{5}{c}{ Program area } & \\
\cline { 2 - 6 } & Defense & Nuclear & $\begin{array}{c}\text { Basic } \\
\text { energy } \\
\text { sciences }\end{array}$ & Fusion & $\begin{array}{c}\text { Health } \\
\text { and } \\
\text { environment }\end{array}$ & $\begin{array}{c}\text { All } \\
\text { other }\end{array}$ & Total \\
\hline $\begin{array}{c}\text { Research funding } \\
\text { (billions of dollars) }\end{array}$ & 1.20 & .80 & .75 & .35 & .25 & 2.45 & 5.80 \\
$\begin{array}{c}\text { Number of scientists } \\
\text { and engineers } \\
\text { (thousands) }\end{array}$ & 12.4 & 8.2 & 7.7 & 3.6 & 2.1 & 2.60 & 60.0 \\
\hline
\end{tabular}

*Source: King Research, Inc.

Table B.2 METHODS OF IDENTIFYING ARTICLES AND

TECHNICAL REPORTS READ BY ENERGY SCIENTISTS AND ENGINEERS IN FIVE DOE PROGRAM AREAS: 1978, 1981

\begin{tabular}{|c|c|c|c|c|c|c|c|}
\hline \multirow[b]{2}{*}{$\begin{array}{c}\text { Method of } \\
\text { identification }\end{array}$} & \multicolumn{6}{|c|}{ Program area } & \multirow[b]{2}{*}{ Average } \\
\hline & Defense & Nuclear & $\begin{array}{c}\text { Basic } \\
\text { energy } \\
\text { sciences }\end{array}$ & Fusion & $\begin{array}{c}\text { Health } \\
\text { and } \\
\text { environment }\end{array}$ & $\begin{array}{c}\text { All } \\
\text { other }\end{array}$ & \\
\hline \multicolumn{8}{|l|}{ Articles, \%* } \\
\hline $\begin{array}{l}\text { While browsing/dis- } \\
\text { tribution copy }\end{array}$ & $-\dagger$ & - & - & - & - & - & 42 \\
\hline From another person & - & - & - & - & - & - & 18 \\
\hline $\begin{array}{l}\text { Cited in another } \\
\text { article/report }\end{array}$ & - & - & - & - & - & - & 15 \\
\hline $\begin{array}{l}\text { Cited in a printed } \\
\text { index }\end{array}$ & - & - & - & - & - & - & 7 \\
\hline $\begin{array}{l}\text { In the output of a } \\
\text { computerized litera- } \\
\text { ture search }\end{array}$ & - & - & - & - & - & - & 18 \\
\hline Reports, \% & & & & & & & \\
\hline $\begin{array}{l}\text { While browsing/dis- } \\
\text { tribution copy }\end{array}$ & 42 & 33 & 42 & 50 & 38 & 53 & 52 \\
\hline From another person & 28 & 22 & 15 & 22 & 28 & 20 & 24 \\
\hline $\begin{array}{l}\text { Cited in another } \\
\text { article/report }\end{array}$ & 6 & 12 & 10 & 4 & 6 & 5 & 8 \\
\hline $\begin{array}{l}\text { Cited in a printed } \\
\text { index }\end{array}$ & 12 & 20 & 17 & 15 & 20 & 13 & 16 \\
\hline $\begin{array}{l}\text { In the output of a } \\
\text { computerized litera- } \\
\text { ture search }\end{array}$ & 12 & 13 & 17 & 9 & 8 & 9 & 12 \\
\hline
\end{tabular}

*Source: King Research, Inc. ${ }^{5}$

$\dagger$ Breakdown of information not available.

$\ddagger$ King Research, Inc., surveys of DOE-funded scientists and engineers. 
Table B.3 ESTIMATED NUMBER OF SEARCHES BY DOE-FUNDED SCIENTISTS AND ENGINEERS IN FIVE DOE

PROGRAM AREAS: 1981*

\begin{tabular}{|c|c|c|c|c|c|c|c|}
\hline \multirow[b]{2}{*}{ Search type } & \multicolumn{6}{|c|}{ Program area } & \multirow[b]{2}{*}{ Total } \\
\hline & Defense & Nuclear & $\begin{array}{c}\text { Basic } \\
\text { energy } \\
\text { sciences }\end{array}$ & Fusion & $\begin{array}{c}\text { Health } \\
\text { and } \\
\text { environment }\end{array}$ & $\begin{array}{c}\text { All } \\
\text { other }\end{array}$ & \\
\hline \multicolumn{8}{|l|}{ On-line: } \\
\hline EDB via RECON & 13,000 & 13,200 & 10,500 & 4,000 & 1,300 & 28,000 & 70,000 \\
\hline NTIS & 7,600 & 7,600 & 6,100 & 2,300 & 800 & 15,600 & 40,000 \\
\hline Others & 28,900 & 7,800 & 6,000 & 5,100 & 2,900 & 13,300 & 64,000 \\
\hline Subtotal & 49,500 & 28,600 & 22,600 & 11,400 & 5,000 & 56,900 & 174,000 \\
\hline \multicolumn{8}{|l|}{$\begin{array}{l}\text { Printed index: } \\
\qquad E R A \text { and other }\end{array}$} \\
\hline TIC & 34,400 & 53,000 & 27,700 & 16,300 & 8,800 & 103,800 & 244,000 \\
\hline Others & $i 6,700$ & 9,300 & 9,100 & 5,600 & 2,800 & 34,500 & 78,000 \\
\hline Subtotal & 51,100 & 62,300 & 36,800 & 21,900 & 11,600 & 138,300 & 322,000 \\
\hline Total & 100,600 & 90,900 & 59,400 & 33,300 & 16,600 & 195,200 & 496,000 \\
\hline
\end{tabular}

*Source: King Research, Inc. 
Table B.4 ESTIMATED NUMBER OF READINGS OF ARTICLES AND TECHNICAL REPORTS IDENTIFIED BY VARIOUS METHODS BY DOE-FUNDED SCIENTISTS AND ENGINEERS IN FIVE

DOE PROGRAM AREAS: 1981*

\begin{tabular}{|c|c|c|c|c|c|c|c|}
\hline \multirow[b]{2}{*}{$\begin{array}{l}\text { Identification } \\
\text { method }\end{array}$} & \multicolumn{6}{|c|}{ Program area } & \multirow[b]{2}{*}{ Total } \\
\hline & Defense & Nuclear & $\begin{array}{c}\text { Basic } \\
\text { energy } \\
\text { sciences }\end{array}$ & Fusion & $\begin{array}{l}\text { Health } \\
\text { and environ- } \\
\text { ment }\end{array}$ & $\begin{array}{c}\text { All } \\
\text { other }\end{array}$ & \\
\hline \multicolumn{8}{|l|}{ Articles } \\
\hline $\begin{array}{l}\text { On-line search-EDB } \\
\text { via RECON }\end{array}$ & 112,000 & 114,000 & 90,000 & 34,000 & 11,000 & 241,000 & 602,000 \\
\hline Other on-line search & 187,000 & 117,000 & 90,000 & 76,000 & 44,000 & 444,000 & 958,000 \\
\hline Subtotal on-line search & 299,000 & 231,000 & 180,000 & 110,000 & 55,000 & 685,000 & $1,560,000$ \\
\hline \multicolumn{8}{|l|}{ Index $-E R A$ and other } \\
\hline TIC & 27,000 & 42,000 & 22,000 & 13,000 & 7,000 & 84,000 & 195,000 \\
\hline Other printed index & 95,000 & 53,000 & 52,000 & 32,000 & 16,000 & 197,000 & 445,000 \\
\hline Subtotal printed index & 122,000 & 95,000 & 74,000 & 45,000 & 23,000 & 281,000 & 640,000 \\
\hline Nonbibliographic & 939,000 & 724,000 & 566,000 & 345,000 & 172,000 & $\underline{2,154,000}$ & $4,900,000$ \\
\hline Total & $1,360,000$ & $1,050,000$ & 820,000 & 500,000 & 250,000 & $3,120,000$ & $7,100,000$ \\
\hline \multicolumn{8}{|l|}{ Reports } \\
\hline $\begin{array}{l}\text { On-line search-EDB } \\
\text { via RECON }\end{array}$ & 82,000 & 83,000 & 66,000 & 25,000 & 8,000 & 176,000 & 440,000 \\
\hline On-line search-NTIS & 114,000 & 114,000 & 92,000 & 34,000 & 12,000 & 244,000 & 610,000 \\
\hline Subtotal on-line search & 196,000 & 197,000 & 158,000 & 59,000 & 20,000 & 420,000 & $1,050,000$ \\
\hline Index-ERA and other & & & & & & & \\
\hline TIC & 196,000 & 302,000 & 158,000 & 93,000 & 50,000 & 591,000 & $1,390,000$ \\
\hline Nonbibliographic & 758,000 & 661,000 & 474,000 & 338,000 & 110,000 & $1,819,000$ & $\underline{4,160,000}$ \\
\hline Total & $1,150,000$ & $1,160,000$ & 790,000 & 490,000 & 180,000 & $2,830,000$ & $6,600,000$ \\
\hline
\end{tabular}

*Source: King Research, Inc. 
Table B.5 EDB-RELATED SEARCHES AND READINGS FROM SEARCHES WITH AND WITHOUT EDB, BY DOE PROGRAM AREA: 1981*

\begin{tabular}{|c|c|c|c|c|c|c|c|}
\hline & \multicolumn{6}{|c|}{ Program area } & \multirow[b]{2}{*}{ Total } \\
\hline & Defense & Nuclear & $\begin{array}{c}\text { Basic } \\
\text { energy } \\
\text { sciences }\end{array}$ & Fusion & $\begin{array}{c}\text { Health } \\
\text { and } \\
\text { environment }\end{array}$ & $\begin{array}{c}\text { All } \\
\text { other }\end{array}$ & \\
\hline \multicolumn{8}{|l|}{ Searches } \\
\hline Current EDB level & 55,000 & 73,800 & 44,300 & 22,600 & 10,900 & 147,400 & 354,000 \\
\hline Without EDB & 8,300 & 10,900 & 6,700 & 3,300 & 1,600 & 21,700 & 52,500 \\
\hline Searches lost & 46,700 & 62,900 & 37,600 & 19,300 & 9,300 & 125,700 & 301,500 \\
\hline \multicolumn{8}{|l|}{ Report readings } \\
\hline Current EDB level & 392,000 & 499,000 & 316,000 & 152,000 & 70,000 & $1,011,000$ & $2,440,000$ \\
\hline Without EDB & - & - & - & - & - & - & - \\
\hline Readings lost & 392,000 & 499,000 & 316,000 & 152,000 & 70,000 & $1,011,000$ & $2,440,000$ \\
\hline \multicolumn{8}{|l|}{ Article readings } \\
\hline Current EDB level & 139,000 & 156,000 & 112,000 & 47,000 & 18,000 & 325,000 & 797,000 \\
\hline Without EDB & 125,000 & 163,000 & 100,000 & 50,000 & 23,000 & 326,000 & 787,000 \\
\hline Readings lost & 14,000 & $-7,000$ & 12,000 & $-3,000$ & $-5,000$ & 1,000 & 10,000 \\
\hline \multicolumn{8}{|l|}{ Total readings } \\
\hline Current EDB level & 531,000 & 655,000 & 428,000 & 199,000 & 88,000 & $1,336,000$ & $3,237,000$ \\
\hline Without EDB & 125,000 & 163,000 & 100,000 & 50,000 & 23,000 & 326,000 & 787,000 \\
\hline Readings lost & 406,000 & 492,000 & 328,000 & 149,000 & 65,000 & $1,010,000$ & $2,450,000$ \\
\hline
\end{tabular}

*Source: King Research, Inc. 
Table B.6 PERCENT OF REPORT READINGS WITH SAVINGS AND AVERAGE SAVINGS IN FIVE DOE PROGRAM AREAS: 1981*

\begin{tabular}{lrrrrrrr}
\hline & \multicolumn{7}{c}{ Program area } \\
\cline { 2 - 7 } & Defense & Nuclear & $\begin{array}{c}\text { Basic } \\
\text { energy } \\
\text { sciences }\end{array}$ & Fusion & $\begin{array}{c}\text { Health and } \\
\text { environment }\end{array}$ & $\begin{array}{c}\text { All } \\
\text { other }\end{array}$ & Average \\
\hline $\begin{array}{l}\text { Report readings with } \\
\text { savings, } \%\end{array}$ & 86 & 74 & 57 & 70 & 75 & 77 & 75 \\
\begin{tabular}{l} 
Average savings, $\$$ \\
\hline
\end{tabular} & 1,230 & 1,530 & 940 & 1,840 & 930 & 1,220 & 1,280 \\
\hline
\end{tabular}

*Source: King Research, Inc.

Table B.7 VALUE OF ENERGY INFORMATION TO SEARCHERS, READERS, AND ORGANIZATIONS/FUNDERS IN FIVE DOE PROGRAM AREAS: 1982* (Millions of Dollars)

\begin{tabular}{|c|c|c|c|c|c|c|c|}
\hline & \multicolumn{6}{|c|}{ Program area } & \multirow[b]{2}{*}{ Total } \\
\hline & Defense & Nuclear & $\begin{array}{c}\text { Basic } \\
\text { energy } \\
\text { sciences }\end{array}$ & Fusion & $\begin{array}{l}\text { Health and } \\
\text { environment }\end{array}$ & $\begin{array}{c}\text { All } \\
\text { other }\end{array}$ & \\
\hline Searchers & 8.8 & 7.2 & 5.5 & 3.2 & 1.6 & 20.7 & 47 \\
\hline Readers & 88 & 78 & 57 & 35 & 15 & 227 & 500 \\
\hline $\begin{array}{l}\text { Organizations/ } \\
\text { funders (DOE) }\end{array}$ & 2200 & 2400 & 1200 & 1200 & 300 & 5,700 & 13,000 \\
\hline
\end{tabular}

*Source: King Research, Inc. 
Table B.8 VALUE OF THE ENERGY DATA BASE TO SEARCHERS, READERS, AND ORGANIZATIONS/FUNDERS IN FIVE DOE PROGRAM AREAS: 1982*

(Millions of Dollars)

\begin{tabular}{lccccccc}
\hline & \multicolumn{7}{c}{ Program area } \\
\cline { 2 - 7 } & Defense & Nuclear & $\begin{array}{c}\text { Basic } \\
\text { energy } \\
\text { sciences }\end{array}$ & Fusion & $\begin{array}{c}\text { Health and } \\
\text { environment }\end{array}$ & $\begin{array}{c}\text { All } \\
\text { other }\end{array}$ & Total \\
\hline $\begin{array}{l}\text { Substitute value of the EDB to } \\
\quad \text { Searchers }\end{array}$ & 2.6 & 3.1 & 2.1 & 0.9 & 0.4 & 5.9 & 15 \\
$\quad \begin{array}{l}\text { Readers } \\
\quad \text { Organizations/funders }\end{array}$ & 15 & 18 & 12 & 6 & 2 & 37 & 90 \\
$\quad$ (DOE) & 500 & 750 & 310 & 270 & 60 & 1,110 & 3,000 \\
$\begin{array}{l}\text { Total value of the EDB to } \\
\quad \text { Searchers }\end{array}$ & 3.4 & 4.0 & 2.7 & 1.2 & 0.5 & 8.2 & 20 \\
$\quad \begin{array}{l}\text { Readers } \\
\text { Organizations/funders }\end{array}$ & 42 & 41 & 29 & 19 & 6 & 103 & 240 \\
$\quad$ (DOE) & 1,300 & 1,600 & 700 & 880 & 150 & 3,370 & 8,000 \\
\hline
\end{tabular}

*Source: King Research, Inc.

Table B.9 VALUE OF RECON TO SEARCHERS, READERS, AND ORGANIZATIONS/FUNDERS IN FIVE DOE PROGRAM AREAS: 1982* (Millions of Dollars)

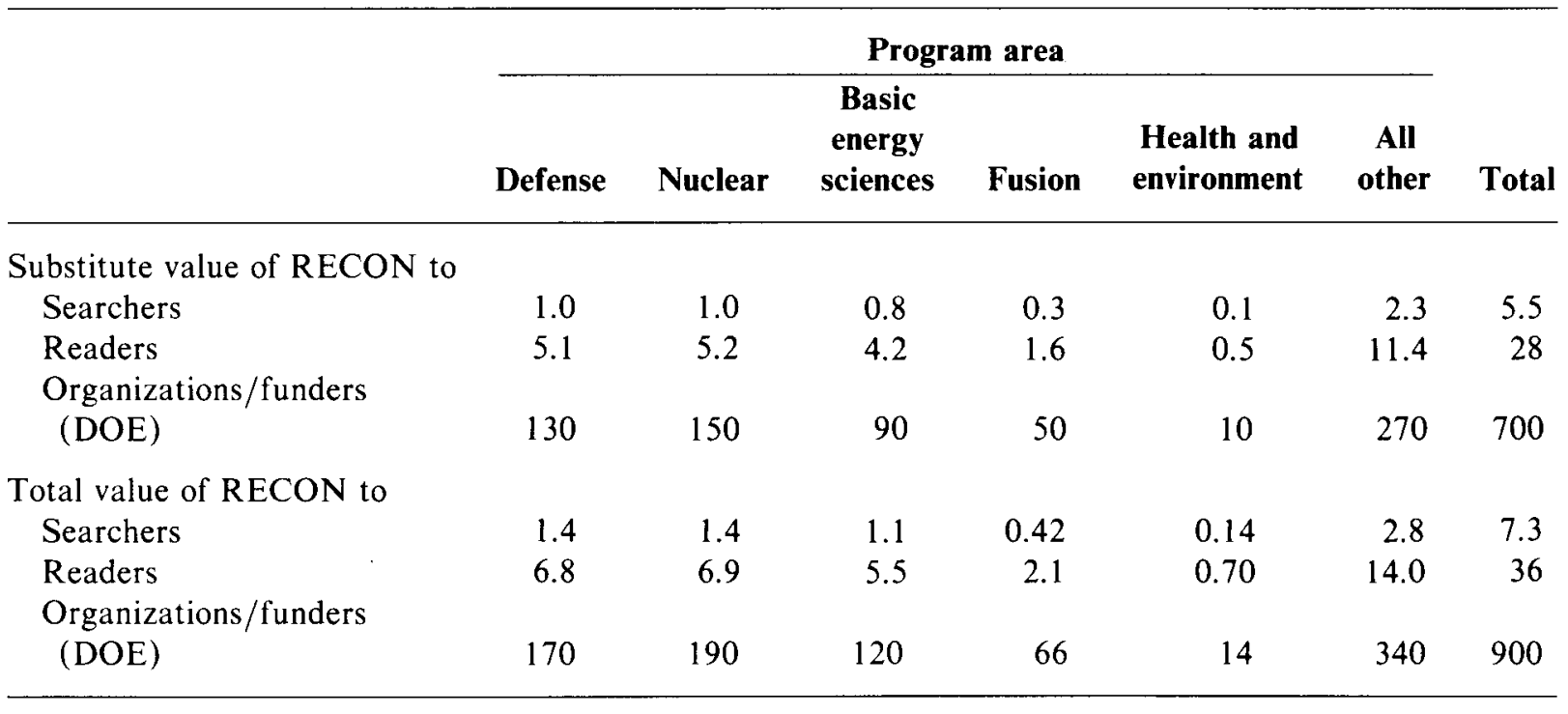

*Source: King Research, Inc. 


\section{APPENDIX C}

\section{SEARCHING COST MODELS}




\section{APPENDIX C}

\section{SEARCHING COST MODELS}

In this Appendix, analyses of a large number of studies are employed, ${ }^{29}$ and detailed cost models are given for manual searching using bibliographic publications such as the Energy Research Abstracts $(E R A)$ and on-line searching of the EDB via RECON, NTIS, and other data bases through data base vendors. In review of the literature, it is found that manual search costs for the sample are consistently higher than on-line search costs. The relative difference, however, varies from $\$ 0.40$ to more than $\$ 200$ with some of the variations attributable to different methods and others to the different types of searches petformed. For the purpose of comparing manual and on-line searches, consideration should be restricted to situations in which the same searches were performed both manually and on-line. When direct comparisons are made, results suggest that on-line search costs are somewhat, if not substantially, higher than for manual searches. However, comparisons should be made on different kinds of searches. When this is done, as shown below, sometimes manual searches are less expensive and sometimes on-line searches are. Below are given details concerning differences in search costs associated with varied degrees of search difficulty.

The estimates of costs begin with manual searching. Under the first estimates, it is assumed that manual bibliographic searches involve an intermediary (librarian or broker) or the user directly and clerical support. Intermediary effort refers to the amount of time spent by the information professional (intermediary) or user in the entire search process. For the person performing a manual search using conventional library reference tools (printed indexes, bibliographies, etc.) preparation time includes the time spent in query negotiation with the user and in the selection of the tools to be consulted. Review time is the amount of time spent after the search is completed. This is usually the time spent reviewing the results before they are presented to the users, although some searches involve cases where the total time includes the time spent by the intermediary in discussing the results with the user. Searching time refers to the amount of time that the intermediary spends in the actual search process. The clerical staff frequently helps by photocopying search results and by shelving materials at the end of a search. Several sources of cost data reported the clerical costs associated with the manual search process. These include time spent photocopying the relevant abstracts located in the abstracting and indexing tools during the search process (photocopying) and the time spent in reshelving the reference tools after use by the librarian (shelving). There are also fixed costs associated with searching, such as materials (a bibliographic publication), space, and telephone. The costs can be subdivided into the elements given in Figure C.1.

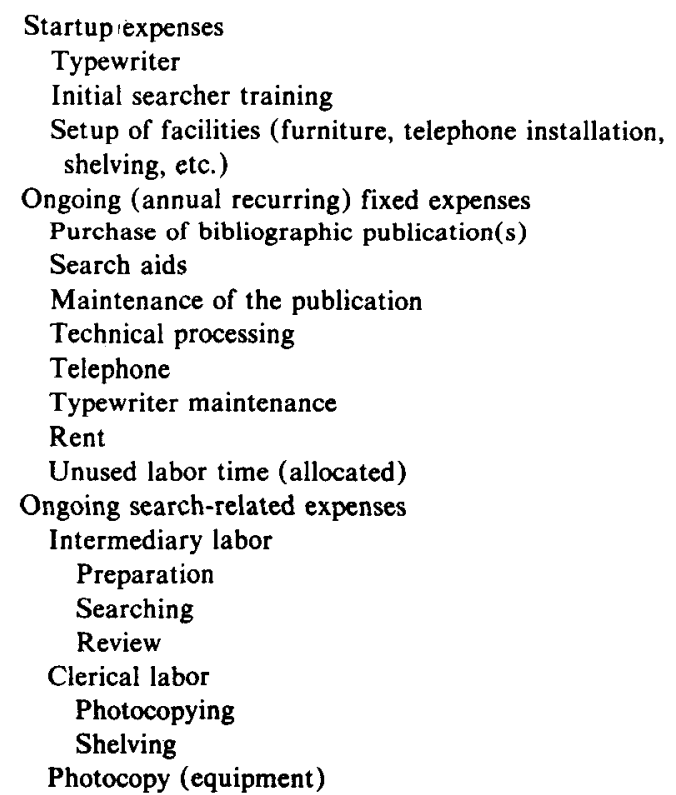

Figure C.1 Cost elements involved in manually searching printed bibliographic publications (Saffady ${ }^{30}$ ).

There are two principal alternative ways of searching bibliographic publications on the behalf of 
DOE-funded scientists and engineers. The first way involves use of the Energy Research Abstracts $(E R A)$ which covers energy technical reports and journal articles that report results of projects funded by the DOE. The second includes searches of technical reports and journal articles found in other bibliographic publications such as Chemical Abstracts, Engineering Index, Biological Abstracts, etc. The second alternative is presented as though the first is not possible, that is, as though $E R A$ does not exist. The principal effects of not having $E R A$ are that organizations must purchase more bibliographic publications and searchers must search through more bibliographic publications. The costs of these two alternatives are discussed below.

The expected costs of the cost elements given in Figure C.1 are presented below in Table C.1. Referring to the startup expenses, we assume that the cost

\begin{tabular}{|c|c|c|c|c|}
\hline & \multicolumn{2}{|c|}{$E R A \dagger$} & \multicolumn{2}{|c|}{ Substitute manual } \\
\hline \multicolumn{5}{|l|}{ Fixed cost elements } \\
\hline Typewriter & $\$$ & 72 & $\$$ & 72 \\
\hline Initial searcher training & & 55 & & 275 \\
\hline $\begin{array}{l}\text { Setup of facilities (furnitu } \\
\text { telephone installation, } \\
\text { shelving) }\end{array}$ & & 78 & & 386 \\
\hline Bibliographic publications & & 0 & & 9,000 \\
\hline Search aids & & 100 & & 100 \\
\hline Maintenance of publicatio & & 50 & & 250 \\
\hline Technical processing & & 75 & & 375 \\
\hline Telephone & & 100 & & 100 \\
\hline Typewriter maintenance & & 22 & & 22 \\
\hline Rent & & 000 & & 1,000 \\
\hline \multirow[t]{2}{*}{ Total } & \multicolumn{2}{|c|}{$\$ 1,552$} & \multicolumn{2}{|c|}{$\$ 11,580$} \\
\hline & Quick & Hard & Quick & Hard \\
\hline \multicolumn{5}{|l|}{ Per search cost } \\
\hline \multicolumn{5}{|l|}{ Professional labor } \\
\hline Preparation & $\$ 1.20$ & $\$ 4.80$ & $\$ 1.20$ & $\$ 19.20$ \\
\hline Searching & 1.20 & 28.80 & 4.80 & 172.80 \\
\hline Review & 0.72 & 3.60 & 0.72 & 3.60 \\
\hline \multicolumn{5}{|l|}{ Clerical labor } \\
\hline Photocopying & 0.46 & 2.30 & 0.46 & 2.30 \\
\hline Shelving & 0.46 & 0.46 & 0.92 & 0.92 \\
\hline Photocopy & 0.10 & 1.30 & 0.10 & 1.30 \\
\hline Total & $\$ 4.14$ & $\$ 41.26$ & $\$ 8.20$ & $\$ 200.12$ \\
\hline
\end{tabular}

* Source: King Research, Inc.

$+E R A$ and other DOE printed indexes.

$\ddagger$ Cost of ERA: \$184; NTIS GRA: $\$ 295 ; 800$ DOE-funded organizations obtain $E R A$ free.

of a typewriter depreciated over five years comes to about $\$ 72$. The cost of initial training for searching $E R A$ is $\$ 220$ which comes to $\$ 55$ allocated over four years. We assume that it costs about five times as much initially to learn to use all of the other bibliographic publications. Similarly the setup costs would be about five times as large for searching all the bibliographic publications. Going to ongoing (annual recurring) fixed expenses, it is found that $E R A$ is distributed free to about 800 DOE-funded organizations. It costs $\$ 84$ to other organizations in the United States. The NTIS Government Research Abstracts costs $\$ 295$. It is assumed that an average of five to ten bibliographic publications (including Chemical Abstracts) would come to about $\$ 9,000$. Other such recurring costs are self-explanatory. The total fixed costs for using $E R A$ come to $\$ 1,462$, and the fixed costs associated with the second alternative are about $\$ 11,580$.

It is found that the amount of time spent in performing manual (and on-line) searches depends largely on the difficulty of search. The difficulty of search is specified in two categories, as follows:

1. Quick search: Here the search involves looking up a single data element, subject term, or citation.

2. Hard search: This includes a straightforward subject search or an exhaustive subject search possibly involving multiple topics or a single topic with different avenues to be pursued. With an on-line method, an average search would contain, perhaps, 3-47 descriptions, 10-52 commands, and 10-185 retrieved references.

A composite of a review of as many as one hundred studies of searching results for manual searches is given below. This composite involves a great deal of judgment.

The average amount of labor time employed manually searching bibliographic publications for the two situations is summarized in Table C.2.

\section{Table C.2 ESTIMATE OF THE AMOUNT OF TIME SPENT BY PROFESSIONAL AND CLERICAL STAFF IN DOE- FUNDED LIBRARIES ON QUICK AND HARD} MANUAL SEARCHES: $1981^{*}$

\begin{tabular}{lccccc}
\hline $\begin{array}{c}\text { Cost } \\
\text { element }\end{array}$ & $\begin{array}{c}\text { Reports (DOE), } \\
\text { in minutes }\end{array}$ & & \multicolumn{2}{c}{$\begin{array}{c}\text { Articles and reports } \\
\text { (Non-DOE), in minutes }\end{array}$} \\
Quick & Hard & & Quick & Hard \\
\hline $\begin{array}{l}\text { Professional labor } \\
\text { Preparation }\end{array}$ & 5 & 20 & & 5 & 40 \\
$\begin{array}{l}\text { Searching } \\
\text { Review }\end{array}$ & 5 & 120 & & 20 & 480 \\
$\begin{array}{l}\text { Clerical labor } \\
\text { Photocopying }\end{array}$ & 3 & 15 & & 3 & 15 \\
Shelving & 2 & 10 & & 2 & 10 \\
\hline
\end{tabular}

*Source: King Research, Inc. 
The proportion of manual searches performed at each level of difficulty appears to be approximately 76 percent quick and 24 percent hard. By applying the average librarian and clerical salaries, adjusted for inflation, one can determine the labor costs for manual searches performed in the DOE-funded libraries. An overhead adjustment of 50 percent is also added to the salaries to account for fringe benefits, unused labor time and other labor-related costs. From recent salary data for librarians with an adjustment for inflation, we use an annual salary of $\$ 19,140$ for DOE-funded librarians and other professionals. Clerical staff earn about $\$ 5.00$ per hour in special libraries. The average labor costs are given in Table C.1, along with all the other cost elements. Two situations are presented. The first situation is where searches are performed on Energy Research Abstracts (ERA) and the organization receives the $E R A$ without charge. The second situation is where articles and reports are both searched by using purchased bibliographic publications from such sources as Chemical Abstract Services, Engineering Information, Inc., etc.

The same cost elements are given by Saffady ${ }^{30}$ for on-line searching. Again cost elements are grouped into three areas: one-time startup expenses, ongoing (recurring) fixed expenses, and ongoing search-related expenses. These expenses are shown in Figure C.2. Startup expenses are those incurred once, before any searching is done. They may recur as, for example, equipment is replaced, but only after a period of some years. They include the purchase price of a terminal, the installation charge, and costs associated with preparation of the physical facilities for searching. If the terminal is used for

Startup Expenses
Terminal
Terminal installation
Site preparation-electrical, telephone installation,
furnishings
Search aids
Initial searcher training
Ongoing fixed expenses
Terminal maintenance
Telephone rental
Searcher training
Rent
Ongoing search-related expenses
Communication charges
Data base use charges
Off-line printing charges
Professional labor
Client interview
Search preparation
Search
Post-search activity

Figure C.2 Cost elements for on-line searching (Saffady ${ }^{30}$ ). other purposes, these costs would have to be allocated to all the uses. Other startup expenses include search aids and initial searcher training. Search aids will include such items as system user manuals, thesauruses, etc. for the specific data bases to be searched; and initial training expenses are related to the system and the data bases the searchers use.

The second category of expenses is ongoing fixed expenses, or those incurred annually. These include terminal maintenance, telephone rental, and additional searcher training. Terminal maintenance is included as an annual expense. If the terminal used is leased, the lease cost would also be included in ongoing fixed expenses and omitted from startup expenses. Telephone rental is also a fixed expense, as is advanced or ongoing searcher training.

The third category of expense includes those directly related to individual searches. These are the costs most often included when search costs are reported; they include both labor and the various charges associated with searching. Included in the labor expenses should be the cost of all search activities, including time at the terminal and also time spent in pre- and post-search activities. Overhead, such as fringe benefits, unusual labor, and administration are included in salary costs. Search charges, which are the most variable part of search expenses, include communication charges, data base use charges, and off-line printing charges. Examples of on-line search costs for searching the EDB via RECON, the NTIS data base and other data bases by vendors are given in Table C.3.

The terminal costs are given as an average between purchasing and depreciating over three years and leasing the same equipment. Since searching other on-line data bases involves several search aids and additional training, the values shown in Table C. 3 are different for them than for RECON and NTIS. The communication charges, data base use and off-line print charges vary by the three types of searches involved because the rates are different and the amount of time used is different. The amount of time assumed for communications and data base use charges is: 4 minutes for quick searches performed of EDB and NTIS; 8 minutes for quick searches on other on-line data bases; 15 minutes for EDB and NTIS hard searches; and 60 minutes for other on-line hard searches. Communication charges are $\$ 0.20$ for each call and about $\$ 0.107$ per minute. RECON users are charged $\$ 28$ per connect hour for both communications and data base use. It costs $\$ 40$ per connect hour to search NTIS and an average of likely data bases to 
Table C.3 COST OF SEARCHING ON-LINE IN DOE FUNDED LIBRARIES OF EDB VIA RECON, NTIS, AND OTHER ON-LINE DATA BASES: 1981*

\begin{tabular}{|c|c|c|c|c|c|c|c|c|c|}
\hline & \multicolumn{2}{|c|}{$\begin{array}{l}\text { EDB via } \\
\text { RECON }\end{array}$} & \multicolumn{2}{|c|}{ NTIS } & \multicolumn{2}{|c|}{$\begin{array}{c}\text { Other } \\
\text { on-line }\end{array}$} & \multicolumn{3}{|c|}{ Substitute } \\
\hline \multicolumn{10}{|l|}{ Fixed cost elements } \\
\hline Terminal & \multicolumn{2}{|c|}{ \$ 900} & \multicolumn{2}{|c|}{$\$ 900$} & \multicolumn{2}{|c|}{$\$ 900$} & \multicolumn{3}{|c|}{$\$ 900$} \\
\hline Terminal installation & \multicolumn{2}{|c|}{50} & \multicolumn{2}{|c|}{50} & \multicolumn{2}{|c|}{50} & \multicolumn{3}{|c|}{50} \\
\hline Site preparation & \multicolumn{2}{|r|}{130} & \multicolumn{2}{|r|}{130} & \multicolumn{2}{|c|}{130} & \multicolumn{3}{|c|}{130} \\
\hline Search aids & \multicolumn{2}{|r|}{100} & \multicolumn{2}{|r|}{100} & \multicolumn{2}{|c|}{100} & \multicolumn{3}{|c|}{1,000} \\
\hline \multicolumn{10}{|l|}{ Initial searcher } \\
\hline training & \multicolumn{2}{|c|}{1,000} & \multicolumn{2}{|c|}{1,000} & \multicolumn{2}{|c|}{1,000} & \multicolumn{3}{|c|}{3,000} \\
\hline Telephone maintenance & \multicolumn{2}{|c|}{20} & \multicolumn{2}{|c|}{20} & \multicolumn{2}{|c|}{20} & \multicolumn{3}{|c|}{20} \\
\hline Telephone rental & \multicolumn{2}{|r|}{150} & \multicolumn{2}{|r|}{150} & & 150 & & 150 & \\
\hline Ongoing searcher & & & & & & & & & \\
\hline training & & .000 & & 000 & & 000 & &, 000 & \\
\hline Rent & &, 000 & & 000 & & 000 & & 000 & \\
\hline Total & & 350 & &, 350 & $\$ 4$ & 350 & $\$ 8$ & 250 & \\
\hline & Quick & Hard & Quick & Hard & Quick & Hard & Quick & $\mathbf{H}$ & lard \\
\hline Per search cost & & & & & & & & & \\
\hline Communication & $\$ 0.20$ & $\$ 0.20$ & $\$ 0.63$ & $\$ 1.80$ & $\$ 0.63$ & $\$ 1.80$ & $\$ 1.06$ & $\$$ & 6.62 \\
\hline Data base use & 1.87 & 7.00 & 2.67 & 10.00 & 5.01 & 18.75 & 10.00 & & 75.00 \\
\hline Off-line printing & 1.09 & 2.17 & 1.22 & 2.43 & 3.64 & 7.28 & 14.35 & & 29.10 \\
\hline Professional labor & & & & & & & & & \\
\hline Client interview & 0.48 & 3.60 & 0.48 & 3.60 & 0.48 & 3.60 & 0.48 & & 3.60 \\
\hline Preparation & 1.44 & 3.60 & 1.44 & 3.60 & 1.44 & 3.60 & 2.76 & & 14.40 \\
\hline Search & 0.96 & 3.60 & 0.96 & 3.60 & 0.96 & 3.60 & 1.84 & & 14.40 \\
\hline Review & 0.72 & 3.60 & 0.72 & 3.60 & 1.44 & 3.60 & 1.44 & & 7.20 \\
\hline Total & $\$ 6.76$ & $\$ 23.77$ & $\$ 8.12$ & $\$ 28.63$ & $\$ 13.60$ & $\$ 42.23$ & $\$ 32.13$ & & 50.32 \\
\hline
\end{tabular}

*Source: King Research, Inc.

be searched through vendors comes to about $\$ 75$ per connect hour. Off-line printing charges are assumed to involve only hard searches. The average off-line print charges for RECON are estimated to be $\$ 0.224$ per page based on the relative amount of searching involving two rates $(\$ 0.25$ and $\$ 0.12$ per page). With the NTIS data base, the charge is $\$ 0.25$ per page and the average for other on-line data bases appears to be about $\$ 0.75$ per page. Based on the RECON data provided by TIC, it appears that an average search involves about 9.7 pages. The total costs associated with the quick and hard searches performed by the three on-line search alternatives are given in Table C.3.

Labor is spent in somewhat different ways for on-line searching and for manual searching. Intermediary labor refers to the amount of time spent by the information professionals (intermediary) or the users, when the search is done by them, in the complete on-line search process. For the searcher in the on-line search process, preparation time includes the time spent in query negotiation with the user, the time spent formulating the search topic into a query suitable for the on-line system(s) and data base(s) to be used, and the time spent consulting any data base guides, thesauruses, or system manuals needed by the search topic. Review time is the time spent by the searcher after the on-line portion of the search in reviewing the results of the search session (with or without the user present). It also could include the time spent in reviewing the search after the results have been received by the user. Searching time refers to the amount of time that the searcher spends on-line, connected to the computer system, and actually executing the search.

The amount of time involved for searches involving different degrees of difficulty is summarized in Table C.4.

Professional labor $(75 \%$ intermediaries and $25 \%$ users) is estimated to cost $\$ 0.24$ per minute. Applying this cost, we arrive at the labor-related cost of the elements of an on-line search, as shown in Table C.3. Again, including degree of difficulty yields substantially different ongoing search-related expenses.

It is worth pointing out that the costs presented are those actually incurred by the library making the searches, which are not necessarily the same as the related costs incurred by other participants in 
Table C.4 ESTIMATE OF THE AMOUNT OF TIME SPENT BY INTERMEDIARIES

ON QUICK AND HARD ON-LINE

SEARCHES: 1981*

\begin{tabular}{lccccc}
\hline \multirow{2}{*}{$\begin{array}{c}\text { Cost } \\
\text { element }\end{array}$} & $\begin{array}{c}\text { RECON and NTIS, } \\
\text { in minutes }\end{array}$ & & \multicolumn{2}{c}{$\begin{array}{c}\text { Other, } \\
\text { in minutes }\end{array}$} \\
\cline { 2 - 2 } \cline { 5 - 6 } & Quick & Hard & & Quick & Hard \\
\hline $\begin{array}{l}\text { Professional labor } \\
\text { Client interview }\end{array}$ & 2 & 15 & & 2 & 15 \\
$\begin{array}{l}\text { Preparation } \\
\text { Searching }\end{array}$ & 6 & 15 & & 12 & 60 \\
Review & 4 & 15 & & 8 & 60 \\
\hline
\end{tabular}

*Source: King Research, Inc.

the search. Like other such estimates, these are sensitive to the pricing schemes used and the way in which both search service and data base costs are allocated to individual searches. Another point worth mentioning is that the costs shown exclude the user's time. This makes sense from the library's point of view, since the library does not pay user salaries; but the point should be taken into account when, for example, the cost effectiveness of different types of searching is compared. User screening costs, in particular, could vary significantly depending on the type of search performed.

Based on the costs derived, comparisons can be made between alternative means of identifying reports and articles.

The key decision affecting search practices is whether to perform manual or on-line searches. One basis for making this decision is to consider the costs of searching by each alternative, together with the amount of searching activity that takes place. For example, in Figure C.3, the costs of searching in 3 separate ways are compared. If less than 170 searches are performed in a year, then it is economically better to do them manually. Above 170, on-line searching is more economical. In this way, the costs of using alternative services are compared.

When looking at the searching patterns of a number of libraries or information centers, it is necessary to group them according to their levels of search activity. Once we have this information, the number of libraries selecting each alternative can be determined. The information can be displayed graphically as indicated in Figure C. 4 .

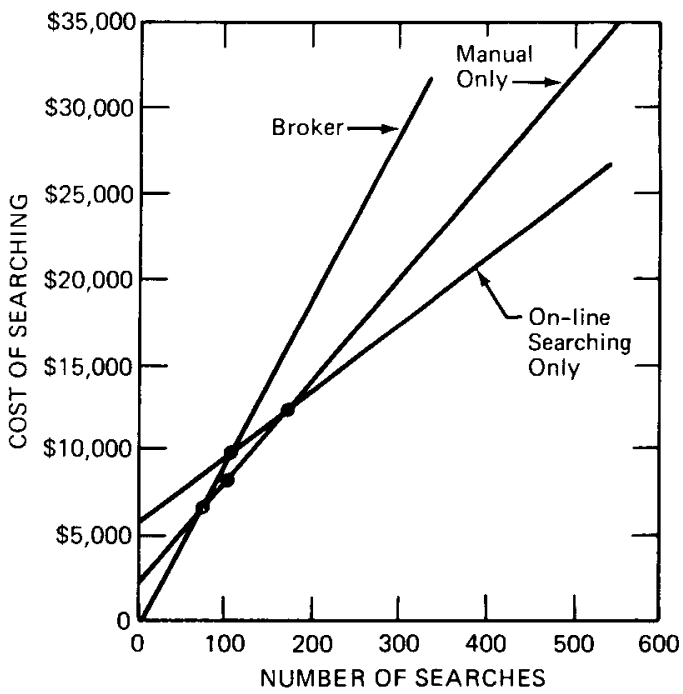

Figure C.3 Cost of searching by broker, manual only, and on-line searching only over number of searches. 


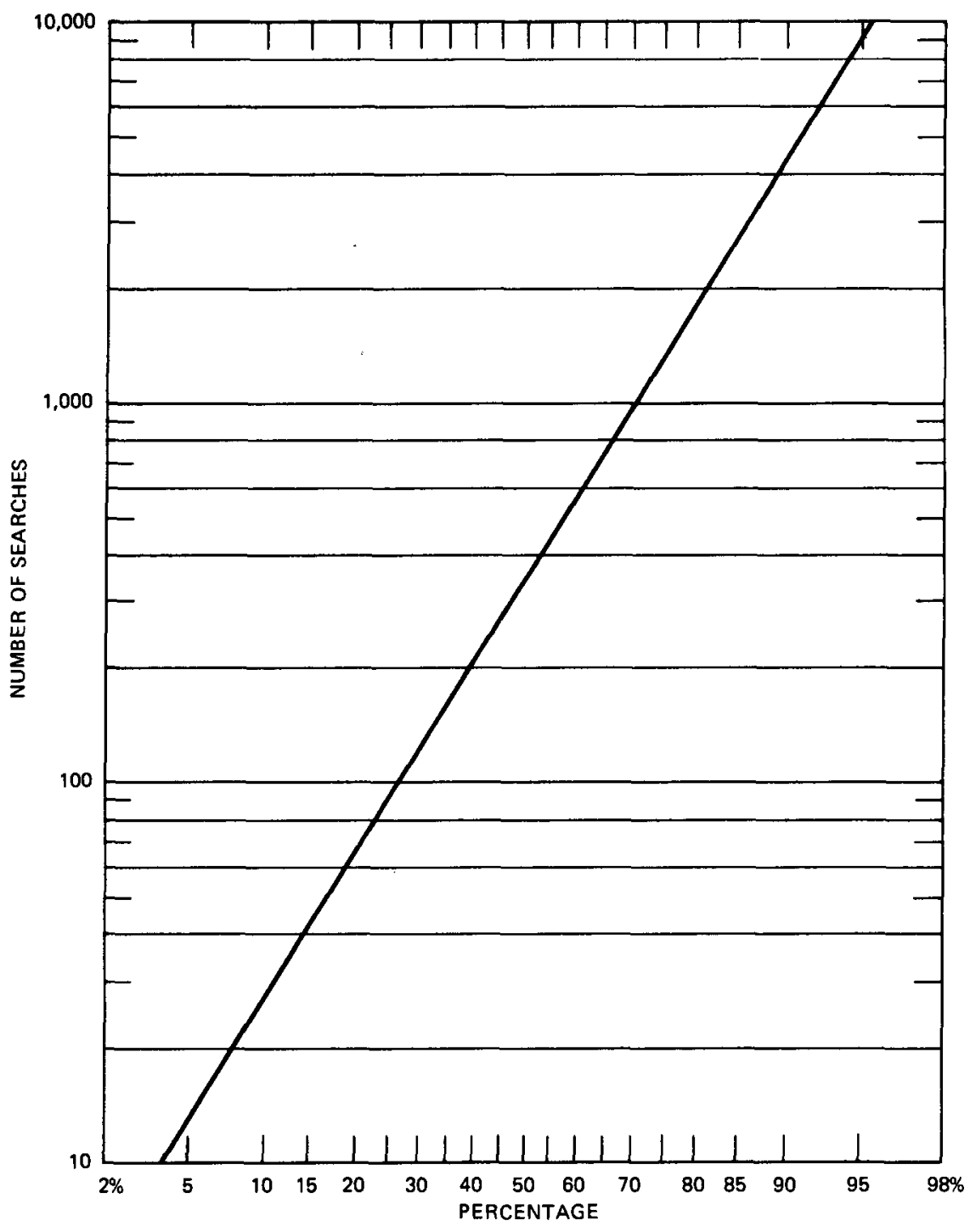

Figure C.4 Cumulative proportion of libraries that perform various numbers of searches. 


\section{APPENDIX D}

\section{SAVINGS FROM REPORT READINGS (INDIVIDUAL RESPONSES)}




\section{SAVINGS FROM REPORT READINGS (INDIVIDUAL RESPONSES)*}

\begin{tabular}{|c|c|c|c|c|}
\hline $\begin{array}{l}\text { Program } \\
\text { area }\end{array}$ & Report topic & $\begin{array}{l}\text { Value of } \\
\text { time saved, } \$\end{array}$ & $\begin{array}{l}\text { Value } \\
\text { of supply } \\
\text { savings, } \mathbf{S}\end{array}$ & How it saved time \\
\hline Defense & $\begin{array}{l}\text { Summary report of highway } \\
\text { vehicle systems }\end{array}$ & 1,600 & - & $\begin{array}{l}\text { Did not have to go and do search for } \\
\text { all materials }\end{array}$ \\
\hline Defense & $\begin{array}{l}\text { Tritium recovery from } \\
\text { fusion blankets }\end{array}$ & 500 & - & $\begin{array}{l}\text { By non-repetition of results, would } \\
\text { have to do tests }\end{array}$ \\
\hline Defense & Decommissioning handbook & $10,000-20,000$ & - & Shortened planning process \\
\hline Defense & $\begin{array}{l}\text { Survey of potential } \\
\text { chlorine production process }\end{array}$ & 1,500 & - & $\begin{array}{l}\text { Would have had to use outside } \\
\text { sources for information }\end{array}$ \\
\hline Defense & Fluidized bed in Morgantown & 500 & - & $\begin{array}{l}\text { Gave background to plan project more } \\
\text { effectively }\end{array}$ \\
\hline Defense & $\begin{array}{l}\text { Controlled potential } \\
\text { electrolysis of gold/platinum }\end{array}$ & 100 & - & Saved literature searching time \\
\hline Defense & & 50 & 50 & $\begin{array}{l}\text { More time on analytical equipment } \\
\text { would have been needed and time to } \\
\text { interpret results }\end{array}$ \\
\hline Defense & $\begin{array}{l}\text { Monitoring tritium in air } \\
\text { containing other data emitters } \\
\text { using iron chambers }\end{array}$ & - & - & $\begin{array}{l}\text { Made user aware of current trends } \\
\text { at the time; would have had to } \\
\text { find them elsewhere }\end{array}$ \\
\hline Defense & $\begin{array}{l}\text { Nature of the steady state of } \\
\text { plutonium in dilute nitric and } \\
\text { hydrochloric acids }\end{array}$ & - & - & $\begin{array}{l}\text { Would have had to do all research } \\
\text { and calculations }\end{array}$ \\
\hline Defense & $\begin{array}{l}\text { Stability of the Pyro } \\
\text { technique mixture titanium } \\
\text { hydride-potassium pachlorate }\end{array}$ & 1,000 & - & Saved search time \\
\hline Defense & $\begin{array}{l}\text { Survey of charcoal of } \\
\text { iodide capture }\end{array}$ & 3,000 & $200-300$ & $\begin{array}{l}\text { Would have had to conduct } \\
\text { experiment to collect information } \\
\text { and data }\end{array}$ \\
\hline Defense & $\begin{array}{l}\text { Thermal analysis of } \\
\text { spirogel microspheres }\end{array}$ & 200 & $20,000-30,000$ & $\begin{array}{l}\text { Would have had to prepare and conduct } \\
\text { experiments and calculations }\end{array}$ \\
\hline Defense & $\begin{array}{l}\text { Pacer FY'74 Final } \\
\text { Report }\end{array}$ & 300 & - & We did not have to get results ourselves \\
\hline Defense & $\begin{array}{l}\text { Lawrence Livermore Lab } \\
\text { report-results and } \\
\text { analysis of the TMX } \\
\text { electron beam injection } \\
\text { experiment }\end{array}$ & 100 & 200,000 & Did not have to duplicate report \\
\hline Defense & $\begin{array}{l}\text { Pakomak stability and } \\
\text { fusion }\end{array}$ & - & - & $\begin{array}{l}\text { The present results are important } \\
\text { to understand }\end{array}$ \\
\hline Defense & $\begin{array}{l}\text { Index of wind turbine } \\
\text { manufacturers }\end{array}$ & 75,000 & 2,000 & $\begin{array}{l}\text { A list such as this was unavailable } \\
\text { elsewhere; a staff would have to } \\
\text { do it for us with cost }\end{array}$ \\
\hline Defense & & - & - & $\begin{array}{l}\text { Suggested ways to increase investment } \\
\text { in several research areas }\end{array}$ \\
\hline Defense & $\begin{array}{l}\text { Financing increased coal } \\
\text { production in the } 1980 \text { s }\end{array}$ & 200 & - & $\begin{array}{l}\text { Did not have to make phone calls and } \\
\text { conduct research personally }\end{array}$ \\
\hline Defense & $\begin{array}{l}\text { Study of alternatives to } \\
\text { National Policy Act } 1978\end{array}$ & 2,000 & - & Would have had to search elsewhere \\
\hline Defense & & 100 & - & It combined materials \\
\hline Defense & & - & - & $\begin{array}{l}\text { Did not have to redo work done by } \\
\text { researchers }\end{array}$ \\
\hline Nuclear & $\begin{array}{l}\text { Advanced international training } \\
\text { course on state systems } \\
\text { of accounting for and } \\
\text { control of nuclear materials }\end{array}$ & - & - & $\begin{array}{l}\text { Prevented duplication of work, } \\
\text { would have had additional } \\
\text { planning and development }\end{array}$ \\
\hline Nuclear & ORNL5818 & 200 & 1,000 & $\begin{array}{l}\text { Would have had to search outside } \\
\text { sources and work out calculations }\end{array}$ \\
\hline Nuclear & & 10,000 & - & Allowed us to use new advanced methods \\
\hline Nuclear & & 5,000 & - & $\begin{array}{l}\text { To see what has been done; get } \\
\text { ideas, shortcuts; quality is better }\end{array}$ \\
\hline
\end{tabular}


SAVINGS FROM REPORT READINGS

(INDIVIDUAL RESPONSES)* (Continued)

\begin{tabular}{|c|c|c|c|c|}
\hline $\begin{array}{l}\text { Program } \\
\text { area }\end{array}$ & Report topic & $\begin{array}{l}\text { Value of } \\
\text { time saved, } s\end{array}$ & $\begin{array}{l}\text { Value } \\
\text { of supply } \\
\text { savings, } \$\end{array}$ & How it saved time \\
\hline Nuclear & $\begin{array}{l}\text { Steam electric plant con- } \\
\text { struction and annual } \\
\text { production expenses }\end{array}$ & 1,000 & - & $\begin{array}{l}\text { Would have had to work out } \\
\text { calculations personally }\end{array}$ \\
\hline Nuclear & $\begin{array}{l}\text { Evaluation and demonstra- } \\
\text { tion of methods for im- } \\
\text { proved nuclear fuel }\end{array}$ & - & - & Would have to get information himself \\
\hline Nuclear & $\begin{array}{l}\text { Bibliography of electrical } \\
\text { discharges in vacuum }\end{array}$ & $\begin{array}{l}\text { Indirect } \\
\text { savings }\end{array}$ & - & $\begin{array}{l}\text { By letting us perform work we could } \\
\text { not otherwise do (without information) }\end{array}$ \\
\hline Nuclear & Oak Ridge Gaseous Diffusion & 10,000 & - & $\begin{array}{l}\text { Assisted in non-duplication of effort, } \\
\text { doubled project size }\end{array}$ \\
\hline Nuclear & & 500 & - & $\begin{array}{l}\text { Would have to spend time organizing } \\
\text { materials }\end{array}$ \\
\hline Nuclear & & 2,000 & - & Would have had to update previous report \\
\hline Nuclear & Waste management & 100 & - & $\begin{array}{l}\text { Information readily available; } \\
\text { eliminated need for other research }\end{array}$ \\
\hline Nuclear & Uranium enrichment & 1,000 & 1,000 & \\
\hline Nuclear & $\begin{array}{l}\text { Safeguards instrumentation } \\
\text { computer base BNL51450 }\end{array}$ & 200 & - & $\begin{array}{l}\text { Would have to reduce all calculations; } \\
\text { would have had to hunt for information }\end{array}$ \\
\hline Nuclear & $\begin{array}{l}\text { Hydrogeneration, coal } \\
\text { gasification }\end{array}$ & 2,000 & 100 & Finding the data without the reports \\
\hline Nuclear & & 500 & 500 & \\
\hline Nuclear & & 1,000 & 500 & $\begin{array}{l}\text { Research led to way to cut cost in } \\
\text { project goals }\end{array}$ \\
\hline Nuclear & Nuclear physics & 1,000 & - & Did not have to redo research themselves \\
\hline Basic & $\begin{array}{l}\text { Fusion Energy Division } \\
\text { Annual Progress Report }\end{array}$ & 1,000 & $1,000+$ & $\begin{array}{l}\text { Would have had to search other sources } \\
\text { of information }\end{array}$ \\
\hline Basic & Wood gasification & 2,000 & $\begin{array}{r}2,000- \\
3,000\end{array}$ & $\begin{array}{l}\text { Would have had to work out calculations } \\
\text { and perform experiment }\end{array}$ \\
\hline Basic & $\begin{array}{l}1982 \text { Minerals Commodities } \\
\text { Summaries Report }\end{array}$ & 2,000 & - & $\begin{array}{l}\text { Would have to be done by user, but } \\
\text { doubts information could be obtained }\end{array}$ \\
\hline Basic & Fate of natural gas market & 3,500 & - & $\begin{array}{l}\text { The reports analyze questions; would } \\
\text { have to dc more reading }\end{array}$ \\
\hline Basic & Coal demonstration plants & 1,000 & 0 & $\begin{array}{l}\text { Would have had to gather more infor- } \\
\text { mation and research }\end{array}$ \\
\hline Basic & Fly-wheel technology & $300-500$ & 0 & Would have to perform analysis himself \\
\hline Basic & & - & - & $\begin{array}{l}\text { Would otherwise have to search } 12 \\
\text { indexes, journals }\end{array}$ \\
\hline Basic & $\begin{array}{l}\text { Exxon Catalytic Coal } \\
\text { Gasification Process } \\
\text { Development Program }\end{array}$ & $4,000-6,000$ & 0 & $\begin{array}{l}\text { Reduced time of research, would have } \\
\text { had to search personally }\end{array}$ \\
\hline Basic & $\begin{array}{l}\text { Coal transport related } \\
\text { article }\end{array}$ & - & - & $\begin{array}{l}\text { Would have had to conduct research on } \\
\text { own or contact other sources }\end{array}$ \\
\hline Basic & $\begin{array}{l}\text { Fundamentals of coal } \\
\text { depolymerization under } \\
\text { hydroliquification }\end{array}$ & 500 & 50 & $\begin{array}{l}\text { Indicated more profitable chemicals } \\
\text { to use in research }\end{array}$ \\
\hline Basic & Synthetic fuels & 100 & 0 & $\begin{array}{l}\text { Information was all together in one } \\
\text { place }\end{array}$ \\
\hline Basic & $\begin{array}{l}\text { Atmospheric studies in } \\
\text { complex terrain }\end{array}$ & 2,000 & - & $\begin{array}{l}\text { Would have had to survey literature } \\
\text { himself }\end{array}$ \\
\hline Basic & $\begin{array}{l}\text { Dessicant air conditioning } \\
\text { from USO Carolina }\end{array}$ & 1,000 & - & $\begin{array}{l}\text { Would have possibly used wrong system } \\
\text { or approach }\end{array}$ \\
\hline Basic & $\begin{array}{l}\text { Double effect absorption } \\
\text { cooling }\end{array}$ & $50,000+$ & - & $\begin{array}{l}\text { Would have required complete design of } \\
\text { a system, including design calculations }\end{array}$ \\
\hline Health & $\begin{array}{l}\text { Survey of carbon and its role } \\
\text { in phosphoric acid fuel cells }\end{array}$ & - & - & Generated ideas \\
\hline Health & $\begin{array}{l}\text { Proceeding of Sth Annual } \\
\text { NEA Sea Bed Working Group }\end{array}$ & 200 & - & $\begin{array}{l}\text { Would have had to look up other sources } \\
\text { and information }\end{array}$ \\
\hline Health & $\begin{array}{l}\text { Coal gasification environ- } \\
\text { mental impact statement }\end{array}$ & - & - & $\begin{array}{l}\text { Would have had to search for and } \\
\text { evaluate data from other } \\
\text { sources }\end{array}$ \\
\hline
\end{tabular}


SAVINGS FROM REPORT READINGS

(INDIVIDUAL RESPONSES)* (Continued)

\begin{tabular}{|c|c|c|c|c|c|}
\hline $\begin{array}{l}\text { Program } \\
\text { area }\end{array}$ & Report topic & $\begin{array}{l}\text { Value of } \\
\text { time saved, } s\end{array}$ & $\begin{array}{c}\text { Value } \\
\text { of supply } \\
\text { savings, } \mathbf{S}\end{array}$ & & How it saved time \\
\hline Health & DOE EV0132 & $1.5 \mathrm{mil}$. & & - & $\begin{array}{l}\text { Fair guide as to environmental } \\
\text { guidelines }\end{array}$ \\
\hline Health & $\begin{array}{l}\text { Coal gasification } \\
\text { processing-SCRI Unit } \\
\text { Design }\end{array}$ & 1,000 & & - & $\begin{array}{l}\text { Collated the information into one } \\
\text { volume so we did not have to do it }\end{array}$ \\
\hline Health & & - & & - & Gave insight into how to change SOP's \\
\hline Health & $\begin{array}{l}\text { Proceeding for high tem- } \\
\text { perature and pressure } \\
\text { particulate and coal } \\
\text { combustion }\end{array}$ & - & & - & $\begin{array}{l}\text { Enables us to get information on foreign } \\
\text { countries with no time delay }\end{array}$ \\
\hline Health & $\begin{array}{l}\text { Telecommunications and } \\
\text { energy savings }\end{array}$ & 100 & & - & $\begin{array}{l}\text { Synthesis of a lot of work in the } \\
\text { area; saved search time }\end{array}$ \\
\hline Health & $\begin{array}{l}\text { Barriers to geothermal } \\
\text { investment }\end{array}$ & 100 & $\therefore$ & - & $\begin{array}{l}\text { Gave quick overview of problem. Would } \\
\text { have had to make calls to industry } \\
\text { people to get information }\end{array}$ \\
\hline Health & $\begin{array}{l}\text { Quarterly technical } \\
\text { progress report }\end{array}$ & 500 & & - & Improved the planning of our project \\
\hline Health & $\begin{array}{l}\text { Storage of US spent power } \\
\text { reactor fuel }\end{array}$ & 100 & & - & $\begin{array}{l}\text { Report had information needed; would } \\
\text { have had to look it up himself }\end{array}$ \\
\hline Health & Low cost silicon survey & 100 & & - & $\begin{array}{l}\text { Would have had to search other } \\
\text { source if possible }\end{array}$ \\
\hline Health & & - & & - & $\begin{array}{l}\text { Did not have to look elsewhere for } \\
\text { information }\end{array}$ \\
\hline Health & Acid rain & - & & - & $\begin{array}{l}\text { Would have had to do literature search } \\
\text { himself }\end{array}$ \\
\hline Health & $\begin{array}{l}\text { Methane production using } \\
\text { cow manure }\end{array}$ & - & & - & $\begin{array}{l}\text { Saved time by not having to find } \\
\text { other materials }\end{array}$ \\
\hline Health & Petrochemical storage systems & 60 & & - & $\begin{array}{l}\text { Would have had to go to primary } \\
\text { sources }\end{array}$ \\
\hline Health & $\begin{array}{l}\text { Progress report from Oregon } \\
\text { State Lab on radiological } \\
\text { environment }\end{array}$ & 1,000 & & - & $\begin{array}{l}\text { To keep abreast on current topics, } \\
\text { was timely }\end{array}$ \\
\hline Health & $\begin{array}{l}\text { Health effects of oil shale } \\
\text { development }\end{array}$ & 50 & & 100 & $\begin{array}{l}\text { Would have had to perform literature } \\
\text { search }\end{array}$ \\
\hline Health & $\begin{array}{l}\text { Understanding cost growth } \\
\text { and performance shortfalls } \\
\text { in pioneer process plants }\end{array}$ & 3,000 & & - & $\begin{array}{l}\text { Would have had to perform } \\
\text { calculations and experiments and } \\
\text { search for more information }\end{array}$ \\
\hline Health & $\begin{array}{l}\text { Environmental impact state- } \\
\text { ments on liquification } \\
\text { techniques }\end{array}$ & 200 & & - & Would have had to gather information \\
\hline Health & $\begin{array}{l}\text { Fossil energy program } \\
\text { summary }\end{array}$ & 5,000 & & - & $\begin{array}{l}\text { Consolidates whole program into } \\
\text { one document }\end{array}$ \\
\hline Health & & $\begin{array}{r}\text { Less than } \\
1,000\end{array}$ & & - & $\begin{array}{l}\text { Would have had to search other sources, } \\
\text { perform calculations }\end{array}$ \\
\hline Health & $\begin{array}{l}\text { Refuse and disposal } \\
\text { options for waste waters } \\
\text { in coal conversion }\end{array}$ & 5,000 & & - & $\begin{array}{l}\text { Would have had to conduct test/ } \\
\text { experiments, search. }\end{array}$ \\
\hline Fusion & $\begin{array}{l}\text { Damage analysis- } \\
\text { fundamental studies }\end{array}$ & - & & - & Would have to search on our own \\
\hline Fusion & $\begin{array}{l}\text { Magnetic fusion project } \\
\text { summary document }\end{array}$ & 1,000 & & - & Would have to prepare summary themselves \\
\hline Fusion & Report on fusion & - & & - & Report was.a means of communication \\
\hline Fusion & & $6,000-8,000$ & & - & $\begin{array}{l}\text { Not duplicating efforts; review other } \\
\text { approaches }\end{array}$ \\
\hline Fusion & $\begin{array}{l}\text { Ion-cyclotron resources } \\
\text { and diffusion at high } \\
\text { energy }\end{array}$ & 10,000 & & - & Did not have to work out problem \\
\hline Fusion & $\begin{array}{l}\text { Electron impact in } \\
\text { excitation of ions }\end{array}$ & 100 & & - & Saved time in going to references \\
\hline
\end{tabular}


SAVINGS FROM REPORT READINGS

(INDIVIDUAL RESPONSES)* (Continued)

\begin{tabular}{|c|c|c|c|c|}
\hline $\begin{array}{l}\text { Program } \\
\text { area }\end{array}$ & Report topic & $\begin{array}{l}\text { Value of } \\
\text { time saved, } \mathbf{s}\end{array}$ & $\begin{array}{c}\text { Value } \\
\text { of supply } \\
\text { savings, } \$\end{array}$ & How it saved time \\
\hline Fusion & $\begin{array}{l}1980 \text { Annual report from } \\
\text { Lawrence Livermore }\end{array}$ & 300 & - & Developments are applicable to research \\
\hline Fusion & $\begin{array}{l}\text { ORNL fusion energy } \\
\text { progress report }\end{array}$ & $4,000-5,000$ & $3,000-4,000$ & $\begin{array}{l}\text { Would have had to work out } \\
\text { calculations, perform search }\end{array}$ \\
\hline Fusion & $\begin{array}{l}\text { Calcium oxide inter- } \\
\text { action in the staged } \\
\text { combustion of coal }\end{array}$ & 10,000 & - & $\begin{array}{l}\text { Helped in planning experiments; } \\
\text { no duplication }\end{array}$ \\
\hline Fusion & Coal flaq properties & $5,000-10,000$ & - & $\begin{array}{l}\text { Identified correlation; did not } \\
\text { have to perform experiment } \\
\text { themselves }\end{array}$ \\
\hline Fusion & $\begin{array}{l}\text { Ion beam propagation } \\
\text { and focussing }\end{array}$ & One man-year & - & $\begin{array}{l}\text { "Gold mine of information"; saved } \\
\text { time in looking up references }\end{array}$ \\
\hline
\end{tabular}

*Verbatim responses of DOE-funded scientists and engineers reporting dollar value of time and/or equipment savings or reason for savings from last technical report read. 


\section{REFERENCES}

1. Machlup, F., Uses, Value, and Benefits of Knowledge, Knowledge: Creation, Diffusion, Utilization, 1(1): 62-81 (September 1979).

2. Taylor, R. S., Value Added Processes in the Information Life Cycle, Syracuse, New York, Syracuse University, School of Information Studies (n.d.).

3. Rich, R., The Value of Information, in Government Information Management, by Elliott Morse and Robert Rich, Boulder, Colorado, Westview Press, 1980.

4. Committee on Scientific and Technical Communication, Report of a Task Group on the Economics of Primary Publication, Washington, D.C., National Academy of Sciences, 1970.

5. King, D. W., D. D. McDonald, and N. K. Roderer, Scientific Journals in the United States: Their Production, Use, and Economics, Stroudsburg, Pennsylvania, Hutchinson Ross Publishing Company, 1981.

6. Hirshleifer, J., and J. G. Riley, The Analytics of Uncertainty and Information-An Expository Survey, Journal of Economic Literature, 17(4): 1375-1421 (December 1979).

7. Taylor, R. S., Information and Productivity: Definitions and Relationships, in Communicating Information, Proceedings of the American Society for Information Science, Volume 17, White Plains, New York, Knowledge Industry Publications, 1980.

8. Mason, R. M., and P. G. Sassone, A Lower Bound Cost Benefit Model for Information Services, Information Processing \& Management, 14: $71-83$ (1978).

9. Berg, S. V., An Economic Analysis of the Demand for Scientific Journals, Journal of the American Society for Information Science, 23: 1, Jan./Feb., 1972.

10. Flowerdew, A. D. J., and C. M. E. Whitehead, Cost-Effectiveness and Cost/Benefit Analysis in Information Science, London, London School of Economics (n.d.).

11. Dammers, H. F., Economic Evaluation of Current Awareness Systems, EURIM Conference, Paris, 1973.
12. Hawgood, J., and R. Morley, Project for Evaluating the Benefits from University Libraries, Durham University, 1969.

13. Wolfe, J. L., et al., The Economics of Technical Information Systems: A Study in CostEffectiveness, University of Edinburgh, 1972.

14. Wills, G., and C. Oldman, An Examination of Cost/Benefit Approaches to the Evaluation of Library and Information Services, in Evaluation and Scientific Management of Libraries and Information Centers, F. W. Lancaster and C. W. Cleverdon (Eds.), Leyden, Noordhoff, 1977.

15. Della Bitta, A. J., E. M. Johnson, and D. L. Loudon, Researching the Value and Use of an Agency's Educational Publications, Journalism Quarterly, 52(2): 326-332 (Summer 1975).

16. Hall, A. M., Comparative Use and Value of INSPEC Services, London, England, Institution of Electrical Engineers, July 1972.

17. Johnson, F. D., et al., NASA Tech Brief Program: A Cost Benefit Evaluation, prepared for the National Aeronautics and Space Administration, Office of Industry Affairs and Technology Utilization, Denver, Colorado, University of Denver Research Institute, May 1977.

18. Mogavero, L. N., Transferring Technology to Industry Through Information, in Information and Industry, AGARD Conference Preprint No. 246, Springfield, Virginia, National Technical Information Service, 1978.

19. Mason, R. M., A Study of the Perceived Benefits of Information Analysis Center Services, Atlanta, Georgia, Metrics, Inc., March 1979.

20. Hounsell, D., P. Payne, and I. Willett, $A$ Small-Scale Examination of the Potential Value of the ERIC Data Base to Educationalists in Britain, Lancaster, England, University of Lancaster, Centre for Educational Research and Development, February 1977.

21. Schwuchow, W., The Economic Analysis and Evaluation of Information and Documentation Systems, Information Processing and Management, 13(5): 267-272 (1977).

22. Baumol, W. J., and J. A. Ordover, Public Good Properties in Reality: The Case of Scientific 
Journals, in Information Politics, Proceedings of the ASIS Annual Meeting, San Francisco, California, October 4-9, 1971, compiled by Susan K. Martin, Washington, D.C., American Society for Information Science, 1976.

23. Hawgood, J., Participative Assessment of Library Benefits, Drexel Library Quarterly, 13(3): 68-83 (July 1977).

24. Marschak, J., Economics of Inquiring, Communicating, Deciding, Richard T. Ely Lecture, The American Economic Review, 58(2): 1-18 (May 1968).

25. Larsen, J., Knowledge Utilization: What Is It?, Knowledge: Creation, Diffusion, Utilization, 1(3): 421-442 (March 1980).

26. Danilov, V. J., C. Herring, and D. J. Hillman, Report of the Panel on Economics of the Science Information Council, Washington, D.C., U. S. National Science Foundation, January 1973.
27. King, D. W., and N. K. Roderer, A Study of Pricing Policies for Information Products and Services, prepared for the U. S. Geological Survey, Rockville, Maryland, King Research, Inc., March 1978.

28. Roderer, N. K., U. S. Expenditures for Biomedical Communications: 1960-1985, prepared for the Lister Hill Center for Biomedical Communications, National Library of Medicine, Rockville, Maryland, King Research, Inc., 1979.

29. Roderer, N. K., D. W. King, R. R. V. Wiederkehr, and H. Zais-Gabbert, Evaluation of Online Bibliographic Systems, prepared for the National Science Foundation, Division of Information Science, Rockville, Maryland, King Research, Inc., September 1981.

30. Saffady, W., The Economics of Online Bibliographic Searching: Costs and Cost Justifications, Library Technology Reports, (SeptemberOctober 1979), 567-653. 


\section{BIBLIOGRAPHY}

Avramescu, A., Actuality and Obsolescence of Scientific Literature, Journal of the American Society for Information Science, 30(5): 296-303 (September 1979).

Baker, C., Human Services Information Clearinghouses: A Discussion of Policy Issues, prepared for The Department of Health and Human Services, Silver Spring, Maryland, Applied Management Sciences, and Santa Monica, California, Cuadra Associates, Inc., September 1981.

Berninger, D. E., and B. W. Adkinson, Interaction Between the Public and Private Sectors in National Information Programs, in Annual Review of Information Science and Technology, Volume 13, White Plains, New York, Knowledge Industry Publications, 1978.

Black, S. H., and A. Marchand, Assessing the Value of Information in Organizations: A Challenge for the Eighties, Research Report No. 80-4, Columbia, South Carolina, University of South Carolina, Bureau of Governmental Research and Service, 1980.

Boulding, K. E., The Economics of Knowledge and the Knowledge of Economics, American Economic Review, 56(2): 1-13 (1966).

Braunstein, Y. M., Costs and Benefits of Library Information: The User Point of View, Library Trends, 28(1): 79-87 (Summer 1979).

Carvey, D., The Relationship of the Government and Private Sector in the Proposed National Program, National Program for Libraries and Information Services Related Paper No. 14, Washington, D.C., National Commission on Libraries and Information Science, November 1974.

Case Institute of Technology, An Operations Research Study of the Dissemination and Use of Recorded Scientific Information, prepared for The National Science Foundation, Office of Scientific Information, Cleveland, Ohio, Case Institute of Technology, December 1960.

Challman, L. E., The Government and Information Costs, Choices, and Challenges, Syracuse, New York, Syracuse University, School of Information Studies, June 1980.
Charles River Associates, Inc., Development of a Model of the Demand for Scientific and Technical Information Services, prepared for the National Science Foundation, Boston, Mass., Charles River Associates, Inc., April 1975.

Commission on Federal Paperwork, Information Value/Burden Assessment, Washington, D.C., U. S. Government Printing Office, September 1977.

Commission on Federal Paperwork, Reference Manual for Program and Information Officials. Volume 2: A Handbook for Technical Information Personnel, Washington, D.C., U. S. Government Printing Office, 1977.

Cuadra, C. A., The Role of the Private Sector in the Development and Improvement of Library and Information Services, Library Quarterly, 50(1): 94-111 (1980).

Existing and Potential Conflicts in Public-Private Interface, Bulletin of the American Society for Information Science, 7(4): 14-15 (April 1981).

Ganz, C., Scientific and Technical Information: Property Rights, Pigou, and Public Intervention, paper presented to the 40th FID Congress, Copenhagen, Denmark, Proceedings of FID Meeting, August 1980.

Goodman, A. F., et al., DOD User-Needs Study, Phase II--Flow of Scientific and Technical Information Within the Defense Industry, Final Report, Volume II: A Technical Description. Volume III: A Frequency Distribution and Correlation; Relationship and Comparison, prepared for the Department of Defense, Anaheim, California, North American Aviation, November 1966.

Goss, K. F., Consequences of Diffusion of Innovations, Rural Sociology, 44(4): $754-772$ (1979).

Institute of Information Scientists, The Value of Technical Information to National and Industrial Economic Development in Britain, Liverpool, England, Institute of Information Scientists, Northern Branch, May 1969.

Johnson, C. A., Repackaging the Information Product, Bulletin of the American Society for Information Science, 7(4): 18-20 (April 1981). 
Keeney, R. L., and H. Raiffa, Decisions with Multiple Objectives: Preferences and Value Tradeoffs, New York, John Wiley \& Sons, 1976.

King, D. W., and D. D. McDonald, Federal and Non-Federal Relationships in Providing Scientific and Technical Information: Policies, Arrangements, Flow of Funds and User Charges, prepared for the National Science Foundation, Rockville, Maryland, King Research, Inc., 1980.

King, D. W., and N. K. Roderer, Information Transfer Cost/Benefit Analysis, in Information and Industry, AGARD Conference Preprint No. 246, Springfield, Virginia, National Technical Information Service, 1978.

King, D. W., and N. K. Roderer, The AIP Journal System: Relationship of Price, Page Charges, Demand, Cost and Income, Proprietary Report, prepared for the American Institute of Physics, Rockville, Maryland, King Research, Inc., July 1981.

King, D. W., N. K. Roderer, and H. Olsen (Eds.), Key Papers in the Economics of Information, prepared for the American Society for Information Science, White Plains, New York, Knowledge Industry Publications (to be published).

King, D. W., P. F. Urbach, and R. R. V. Wiederkehr, Experimentation, Modeling and Analysis to Establish a New Pricing Policy at CFSTI, Rockville, Maryland, King Research, Inc., 1967.

Lamberton, D. M., National Policy for Economic Information, International Social Science Journal, 28(3): 449-465 (1976).

Lave, L. B., and J. Fedorowicz, Government Policy Toward the Dissemination of Scientific and Technical Information, prepared for the National Science Foundation as part of the FCC SET Review of Dissemination of Scientific and Technical Information, Washington, D.C., National Science Foundation, 1980.

Levitan, K. B., The Collapse of Traditional Distinctions, Bulletin of the American Society for Information Science, 7(4): 12-13, 16 (April 1981).

Levitan, K. B., The New Information Hybrid, Bulletin of the American Society for Information Science, 7(4): 25-26 (April 1981).

Magson, M. S., Techniques for the Measurement of Cost-Benefit in Information Centres, ASLIB Proceedings, 25(5): 164-185 (May 1973).

McDonald, D. D., D. W. King, L. L. King, A. S. Levitz, K. T. O'Brien, N. K. Roderer, and C. G. Schell, Cost and Usage Study of the Educational Resources Information Center (ERIC)
System, prepared for the National Institute of Education, Rockville, Maryland, King Research, Inc., September 1981.

National Commission on Libraries and Information Science, Public Sector/Private Sector Interaction in Providing Information Services, Report to the NCLIS from the Public Sector/Private Sector Task Force, Washington, D.C., NCLIS, August 1981.

National Science Board, National Science Foundation, Science Indicators 1978, Wash- ington, D.C., Government Printing Office, 1979.

Nelson, S. D., Knowledge Creation: An Overview, Knowledge: Creation, Diffusion, Utilization, 1(1): 123-149 (September 1979).

Newman, G., An Institutional Perspective on Information, International Social Science Journal, 28(3): 466-492 (1976).

Olson, M., Information as a Public Good, in Economics of Information Dissemination, R. S. Taylor (Ed.), Syracuse, New York, Syracuse University, School of Library Science, 1973.

Read, W. H., The U. S. Faces WARC: Information as a National Resource, Journal of Communication, pp. 172-178 (Winter 1979).

Rich, R. F., The Use of Information as an Indicator of Value, in Government Information Management: A Counter-Report of the Commission on Federal Paperwork, Boulder, Colorado, Westview Press, 1980.

Roderer, N. K., and C. H. Olsen, The Information Dissemination Program of IIASA in the United States, prepared for the National Science Foundation, Rockville, Maryland, King Research, Inc., 1978.

Sassone, P. G., and W. A. Schaffer, Cost-Benefit Analysis: A Handbook, New York, Academic Press, 1978.

Science and Technology Team, Federal Scientific and Technical Information, Federal Data Processing Reorganization Study, reprinted in Information Hotline, 10(9): 10-13 (October 1978).

Science, Government, and Information, A Report of the President's Science Advisory Committee, Washington, D.C., The White House, January 1963.

Thompson, M. S., Benefit-Cost Analysis for Program Evaluation, Beverly Hills, California, Sage Publications, 1980.

Usdane, B. S., U. S. Government Publications: Their Value, Online Accessibility and Availability for International Information Needs, Online Review, 4(2): 143-152 (June 1980). 
Yin, R. K., and M. K. Gwaltney, Knowledge Utilization as a Networking Process, Knowledge: Creation, Diffusion, Utilization, 2(4): 555-580 (June 1981).

Yurow, J. H., et al., Issues in Information Policy, Washington, D.C., National Telecommunications and Information Administration, U. S. Department of Commerce, February 1981.

Zaltman, G., Knowledge Utilization as Planned Social Change, Knowledge: Creation, Diffusion, Utilization, 1(1): 82-105 (September 1979). 
